\title{
O TURISMO E A RETÓRICA PUBLICITÁRIA: UM ESTUDO DE CASO DE FOLHETOS DE REVISTAS DE AGÊNCIAS DE TURISMO DO DISTRITO FEDERAL SOB A ÓTICA DA ANÁLISE DO DISCURSO DE CHAIN PERELMAN (1996).
}

\author{
Paulo Henrique Marques Costa
}

ORIENTADORA: PROFA. (MSC) ANA MARIA DE MORAES SARMENTO VELLASCO

Monografia apresentada ao Centro de
Excelência em Turismo (CET) da
Universidade de Brasília (UnB) como
requisito parcial para a obtenção do
certificado de Especialista em Turismo e
Hospitalidade.


Brasília, Distrito Federal, fevereiro de 2004.

UNIVERSIDADE DE BRASÍLIA (UNB)

Centro de Excelência em Turismo (CET)

Curso de Especialização em Turismo e Hospitalidade

O TURISMO E A RETÓRICA PUBLICITÁRIA: UM ESTUDO DE CASO DE FOLHETOS DE REVISTAS DE AGÊNCIAS DE TURISMO DO DISTRITO FEDERAL SOB A ÓTICA DA ANÁLISE DO DISCURSO DE CHAIN PERELMAN (1996).

Paulo Henrique Marques Costa

Banca Examinadora

PROFA. (MSC) ANA MARIA DE MORAES SARMENTO VELLASCO 
FICHA CATALOGRÁFICA

COSTA, PAULO HENRIQUE MARQUES.

O TURISMO E A RETÓRICA PUBLICITÁRIA: UM ESTUDO DE CASO DE FOLHETOS DE REVISTAS DE AGÊNCIAS DE TURISMO DO DISTRITO FEDERAL SOB A ÓTICA DA ANÁLISE DO DISCURSO DE CHAIN PERELMAN (1996)./Paulo Henrique Marques Costa Brasília, 2004.

131 p., 210x297mm (CET/UnB, Especialização, Centro de Excelência em Turismo, 2004).

Monografia de Especialização - Centro de Excelência em Turismo - Universidade de Brasília, 2004.

Área: Turismo e Hospitalidade

Orientadora: Profa. MSc. Ana Maria de Moraes Sarmento Vellasco

Palavras-chave 1. Turismo, 2. Retórica, 3. Análise do discurso, 4. Folhetos.

REFERÊNCIA BIBLIOGRÁFICA

COSTA, Paulo Henrique Marques. (2004) / O turismo e a retórica publicitária:Um estudo de caso de folhetos de revistas de agências de turismo do Distrito Federal sob a ótica da análise do Discurso de Chain 
Perelman (1996). Paulo Henrique Marques Costa. Monografia de Especialização - Centro de Excelência em Turismo - Universidade de Brasília, Brasília FOLHA DE APROVAÇÃO

Profa. MSc. Ana Maria de Moraes Sarmento Vellasco — Orientadora 
Dedico esta monografia a meu pai, Francisco Rodrigues da Cunha, minha mãe, Maria da Conceição Marques Costa, que, pela distância, não puderam acompanhar o desenvolvimento deste trabalho, mas sempre me apoiaram com palavras de conforto e incentivo diante das adversidades.

À minha amada esposa, Maria Idalina da Cruz Costa, pelo amor, carinho, incentivo constantes e os abençoados e sempre alegres Matheus Henrique da Cruz Costa e Gabriel Henrique da Cruz Costa, meus filhos, que chegaram na hora certa, trazendo um toque especial a nossas vidas. 


\section{AGRADECIMENTOS}

Em especial, a todos os funcionários do Centro de Excelência em Turismo, sobretudo ao Pedro que procurou nos atender sempre com muita paciência e benevolência.

Aos colegas do curso de especialização em Turismo e Hospitalidade, que, quando solicitados, atenderam-me com toda atenção e cuidado.

À professora Ana Maria de Moraes Sarmento Vellasco, pelas constantes orientações e pelo grande apoio ao longo desses meses de trabalho. 
Para se sentir à vontade em um país estrangeiro, não basta falar a língua. Qualquer comunicação com pessoas de culturas diferentes carrega um conjunto de atitudes, gestos, marcas de cortesia (polidez) que, às vezes, escapam, outras vezes nos desconcertam, pois elas podem variar de um país a outro. Conhecer essas regras mais ou menos codificadas que constituem o saber viver, a arte de bem viver e as boas maneiras de um povo, é tão essencial quanto conhecer a gramática de uma língua para compreender a sua estrutura... 
Grand-Clément (2001:4)

\section{RESUMO}

O presente trabalho monográfico tem como ponto principal a análise do discurso que permeia toda a publicidade no turismo, tomando-se como objetos empíricos de análise 208 folhetos colhidos de várias revistas de turismo do Distrito Federal. Assim, tem-se a necessidade de analisar os processos comunicativos e, desse, modo, averiguar a influência sobre a adesão de um lado do público: o leitorturista. $^{1}$

Dessa forma, o princípio gerador será investigar, à luz da análise do discurso de Chain Perelman (1996), folhetos e panfletos publicitários de revistas de turismo de Brasília, Distrito Federal, verificando como ocorre o nível de manipulação e sedução desses materiais nas agências de turismo e como o turista tende a ser persuadido pelos argumentos contidos nesses materiais publicitários a serviço da indústria de turismo.

\footnotetext{
${ }^{1}$ Usarei essa nomenclatura ao longo da análise.
} 


\begin{abstract}
The present paper has as the principal point the analysis of the discourse that enphasizes all the publicity in the tourism, taking as the empirical analysis objects 208 folders which are taken from varies magazines of the tourism in Federal District, in Brasilia. This way, it has the necessity of analyzing the comunication processes and verify the influence under the adesion of the one side of the publico: the touristreader. $^{2}$

However, the main principle will be to investigate, according to the analysis of the discourse from Chain Perelman (1996), publicity folders from magazines of tourism of Brasilia, Federal District, verifying how happens the level of manipulation e seduction of these materials in the tourisms agencies and how the tourist can be persuaded by the arguments that are put in these publicities material in service of tourism industry.
\end{abstract}

\footnotetext{
${ }^{2}$ I will use this term during evey part of the analysis.
} 
SUMÁRIO

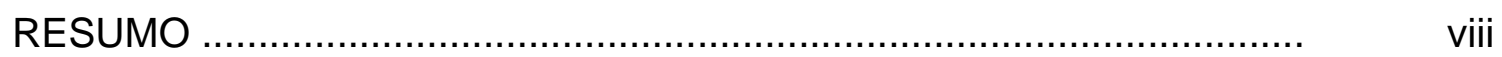

ABSTRACT

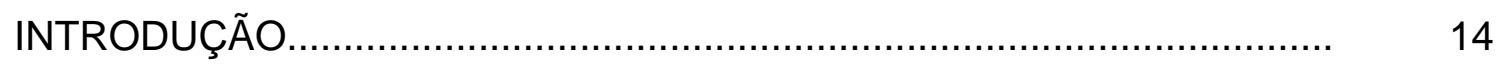

METODOLOGIA DE PESQUISA....................................................... 17

CAPÍTULO I: OS NÍVEIS DA ARGUMENTAÇÃO NOS FOLHETOS

TURÍSTICOS E O TURISMO COMO FENÔMENO DE MASSA................ 18

1.1. Demonstração e argumentação nos folhetos................................... 18

1.2. O orador (sujeito) e o seu auditório (leitores) dos folhetos.................. 20

1.3. Persuadir e convencer nos folhetos................................................. 21

1.4. A argumentação perante o leitor-turista............................................ 23

1.5. A argumentação, a educação e os folhetos turísticos........................ 24

1.6. Folhetos e envolvimento da argumentação........................................... 27

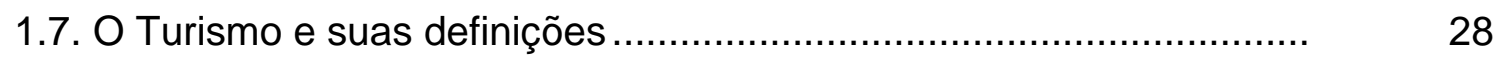

1.8. Tipos de turismo .................................................................

1.9. As formas de turismo …………..................................................

CAPÍTULO II: O PONTO DE PARTIDA DA ARGUMENTAÇÃO

DOS FOLHETOS E FOLDERS.............................................................

2.1. As premissas da argumentação..................................................

2.2. Os fatos e as verdades nas entrelinhas dos folhetos e folders.......... $\quad 35$

2.3. Os valores abstratos e os valores concretos nos folhetos e folders.... 36

2.4. As hierarquias discursivas nos folders.......................................... $\quad 39$

2.5. A análise do discurso................................................................

2.6. A propaganda e a publicidade....................................................

CAPÍTULO III: A ADAPTAÇÃO DOS FOLDERS 
COM VISTAS À ARGUMENTAÇÃO E A RETÓRICA........................... 47

3.1. A interpretação dos folhetos analisados................................... 47

3.2. A interpretação do discurso dos folders....................................... 48

3.3. Usos argumentativos dos folders e folhetos ................................. 49

CAPÍTULO IV: OS DADOS DOS FOLDERS E FOLHETOS

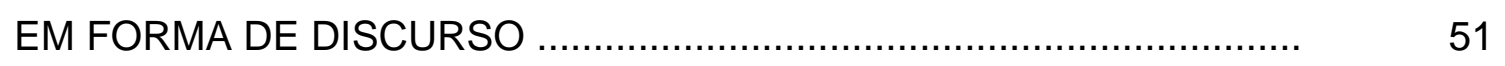

4.1. Formas verbais e argumentação............................................... 51

4.2. As modalidades na expressão do pensamento ............................ 53

4.3. Formas de discurso nos folders e os elementos de argumentação... 55

CAPÍTULO V: AS TÉCNICAS ARGUMENTATIVAS USADAS

NOS FOLHETOS E FOLDERS ANALISADOS …............................... 5

5.1. Características da argumentação quase lógica............................ 57

5.2. Contradição e incompatibilidade ........................................... 58

5.3. Técnicas que visam apresentar teses como compatíveis

ou incompatíveis ............................................................... 59

5.4. Os argumentos de comparação e de reciprocidade........................ 60

CAPÍTULO VI: OS ARGUMENTOS BASEADOS NA ESTRUTURA

DO REAL DOS FOLDERS E FOLHETOS ...................................... 61

6.1.O vínculo causal e a argumentação .............................................. 61

6.2. O argumento pragmático.................................................. 62

CAPÍTULO VII: AS LIGAÇÕES QUE FUNDAMENTAM A

ESTRUTURA DO REAL ....................................................... 63

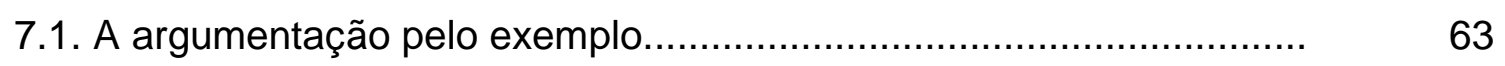

7.2. Relações entre os termos de uma analogia ................................... 64

7.3. Efeitos da analogia ....................................................... 65 
7.4. As expressões com sentido metafórico....................................... 67

CAPÍTULO VIII: AS DISSOCIAÇÕES DAS NOÇÕES ........................... 68

8.1. Ruptura de ligação e dissociação............................................... 68

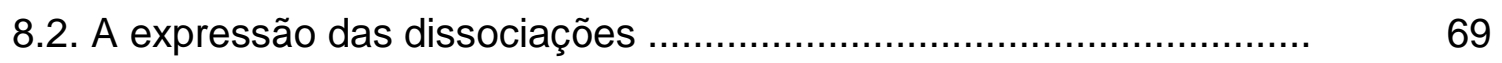

8.3. Enunciados que incentivam dissociação...................................... 70

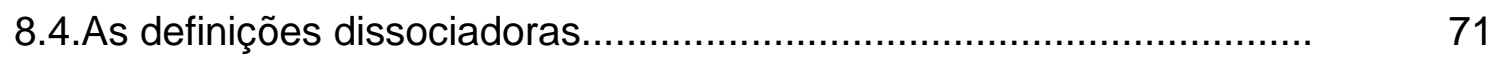

CAPÍTULO IX: A INTERAÇÃO DOS ARGUMENTOS ............................ 73

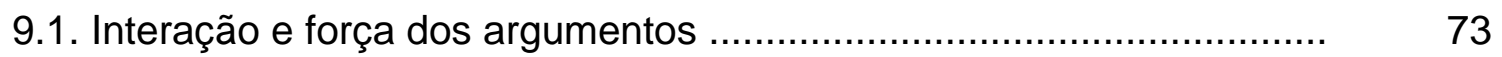

9.2. A apreciação da força dos argumentos, fator de argumentação.......... 74

9.3. Ordem e persuasão ................................................................... 75

9.4. Ordem do discurso e condicionamento ..................................... 77

CONSIDERAÇÕES FINAIS ............................................................ 81

REFERÊNCIAS BIBLIOGRÁFICAS ............................................... 84

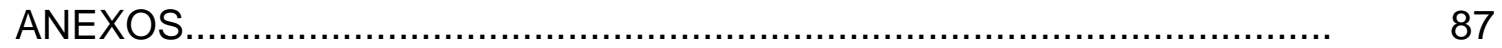

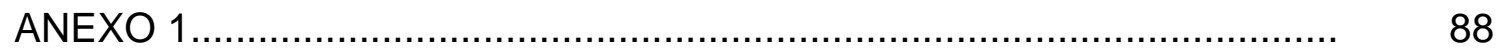

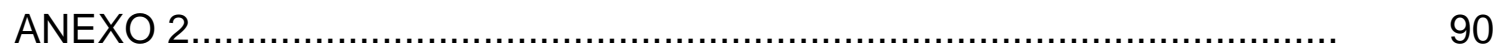

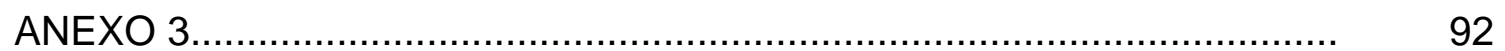

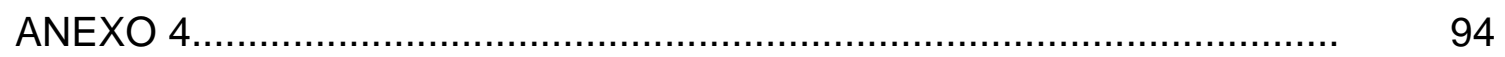

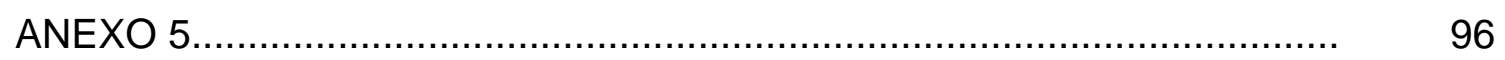

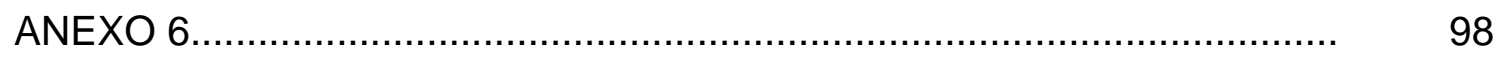

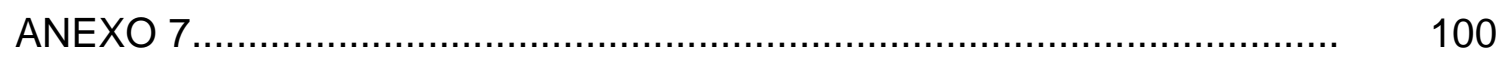

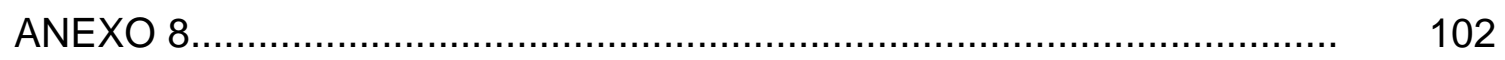

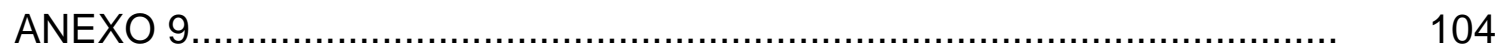

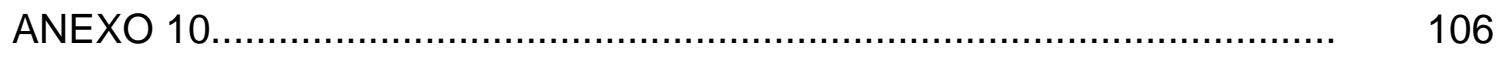

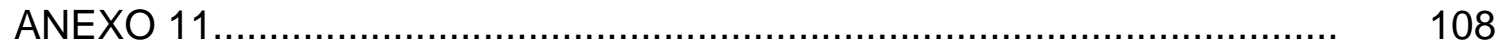

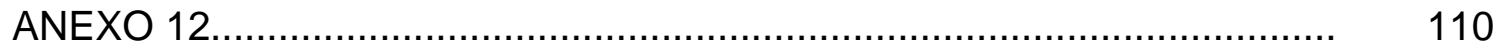

ANEXO 13.................................................................................. 112

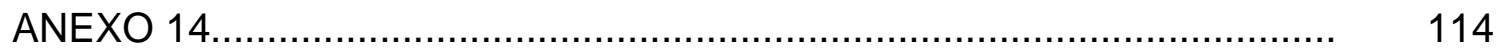

ANEXO 15 


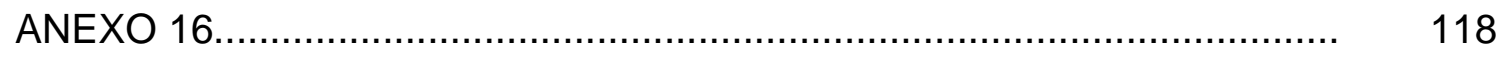

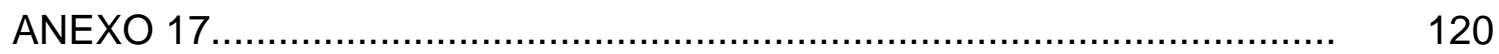

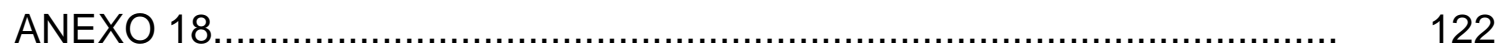

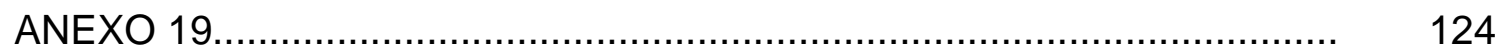

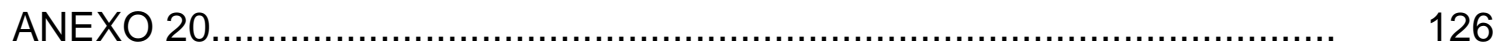

ANEXO 21

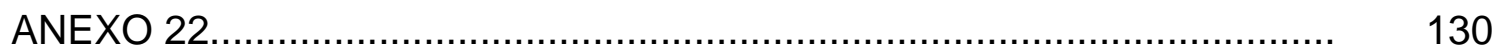

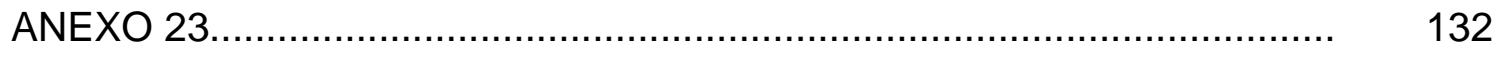

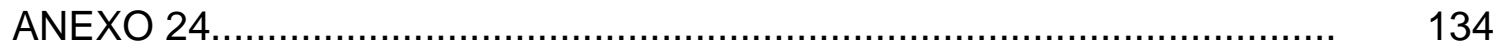

ANEXO 25

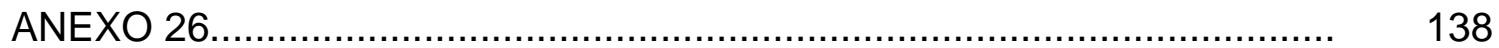

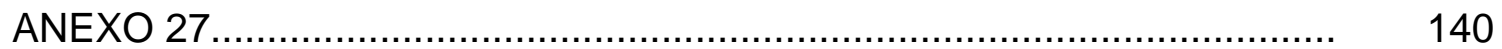

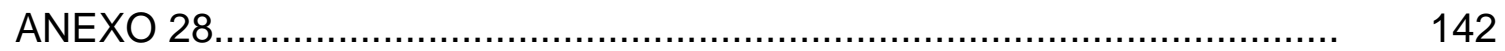

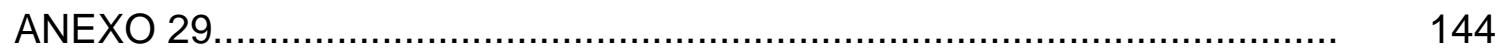

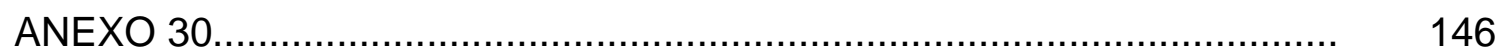

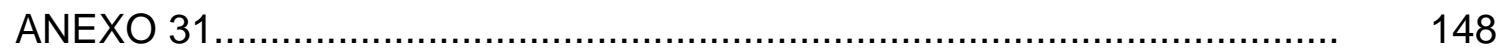

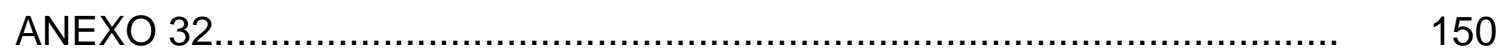

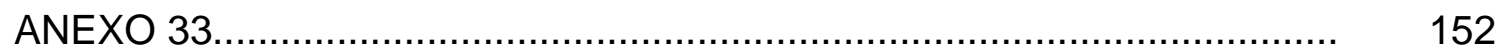

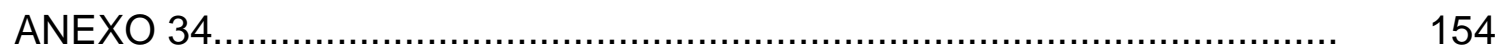

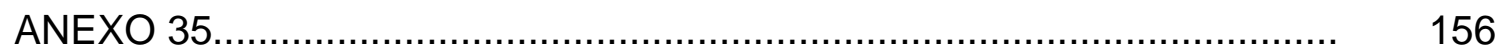

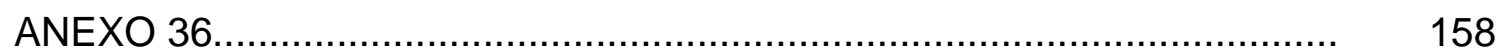

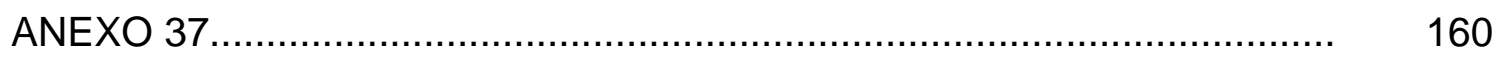

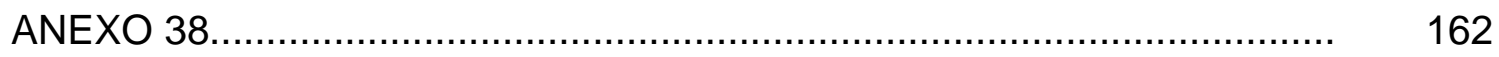

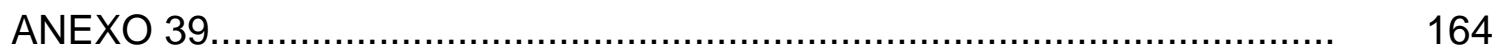

ANEXO 40

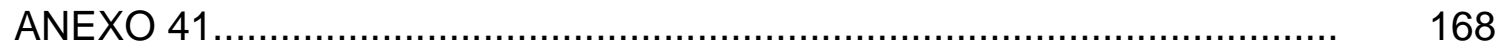

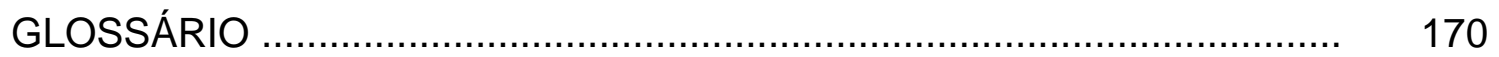




\section{INTRODUÇÃO}

Com base na análise dos folhetos e folders selecionados, inferir-se-á que não há como pensar em turismo sem contextualizá-lo ao processo de globalização, o grande fenômeno da contemporaneidade. Assim, no paradigma de novos signos, no ritmo de novos tempos, os turistas opõem-se às fronteiras, percorrem o mundo para experimentá-los e têm no avião, no ônibus e, sobretudo, nas revistas e até na Internet os instrumentos para um enriquecimento cultural.

Dessa forma, percebe-se que são muito interessantes as contribuições da Sociologia, da Psicologia, da Lingüística e da Análise do Discurso, fazendo uma ponte com o campo da pesquisa em turismo, que investigam a percepção e o imaginário que expressam no comportamento individual e coletivo da demanda turística.

A intensa atividade humana, os desgastes do cotidiano, aliados às conquistas do homem moderno como o tempo livre diário, semanal e anual cada vez maior, levam a sociedade a procurar recursos capazes de fornecer aos indivíduos os necessários meios para atingir as suas aspirações, entre as quais a prática do turismo, cujas principais motivações são: necessidade e desejo de fuga ou evasão, espírito de aventura, aquisição de status quo, necessidade de tranqüilidade, desejo ou necessidade cultural ou, finalmente, desejo ou necessidade de compra. Tal necessidade imperiosa de viajar é fabricada e incorporada artificialmente ao rol das necessidades do homem urbano que o tornam o homem viajante.

Com o objetivo de satisfazer essas fantasias, as agências de turismo, por meio de revistas, folhetos e folders, procuram oferecer, por meio de semióticas obscuras, códigos tácitos, envoltos sutilmente no imaginário coletivo, opções de 
viagens e roteiros que propõem uma reconstrução fantasiosa de um mundo globalizado.

Nas suas campanhas publicitárias em que a Retórica ocupa um lugar preponderante, elas resgatam esses sonhos e os transformam em ação. Por meio de uma linguagem e de meios de informação cuidadosamente elaborados, difunde-se uma imagem de um modo de vida e de uma ideologia inspirados por grupos sociais privilegiados, os quais convém imitar pelos seus comportamentos e hábitos de consumo. Assim, a publicidade deixa de ser apenas um convite à viagem, ela se inspira na insatisfação e vende o espaço turístico como um paraíso que se constitui numa tentativa de resposta do imaginário coletivo.

Por isso, o homem viajante - aqui chamado de leitor-turista - busca atender às suas necessidades e anseios, partindo do conhecido ao desconhecido, de dentro para fora, do interior de si mesmo para o exterior do outro. Buscando o desconhecido, a aventura, o exótico e o inusitado, ele se volta para as cidades paradisíacas, reforçando o mito do eterno retorno, resultado de agressivas campanhas da mídia que incentivam novas modalidades de turismo.

O consumo do espaço sobrepõe-se ao consumo produtivo e a instalação de onerosas infra-estruturas de apoio ao turismo, como, por exemplo, os transportes e as empresas hoteleiras e de equipamentos de lazer, requerem grande volume de investimentos de capital.

Em vista do apresentado, a referida dissertação tem como objetivos: a) analisar o processo argumentativo empregado nos 208 folhetos e folders publicitários das agências de turismo no Distrito Federal, seguindo as idéias de Chain Perelman (1996) no seu Tratado de Argumentação, de que os processos comunicativos têm por finalidade conseguir a adesão do leitor-turista, verificando-se que se exercita por meio da discursividade com o objetivo de dirigir e influenciar a opinião do públicoturista; b) Investigar como esses elementos obtêm uma maior força argumentativa ao se associarem no processo de convencimento, de sedução e de persuasão que os folhetos e o folders dessas revistas provocam no turista. 
Em síntese, o eixo referencial teórico será fundamentado nos construtos da análise do discurso no seu Tratado da Argumentação de que os processos comunicativos têm por finalidade conseguir a adesão do turista. Por isso, segundo Perelman (1996), pode-se afirmar que todo o trabalho baseia-se em três pontos fundamentais:

a) a argumentação, que tem como finalidade provocar ou aumentar a adesão de um público por meio do discurso, que apresentará argumentos universalizantes;

b) o orador, que produz o discurso, facultando-lhe emoção, vontade, ou razão, que segundo Perelman é usada para dirigir as nossas ações e para influenciar a dos outros;

c) o público que pode ser universal ou particular e cujos fatores psicológicos, afetivos, socioculturais e ideológicos devem ser levados em consideração;

Dessa forma, esta monografia será desenvolvida em dez capítulos aplicados à análise dos 208 folhetos de turismo retirados das revistas pesquisadas. A partir disso, os folhetos e folders serão considerados segundo os níveis da argumentação, o ponto de partida da argumentação, a adaptação desses folders e folhetos com vistas à argumentação e a retórica, os dados dos folhetos e folders em forma de discurso.

No primeiro capítulo serão desenvolvidos os níveis de argumentação nos folhetos analisados; o segundo abordará as premissas, os valores, os fatos e as verdades, assim como as hierarquias discursivas nos folders; o terceiro tratará do nível de adaptação dos folders analisados com os conceitos de argumentação e retórica; o quarto analisará as formas verbais, as modalidades e os elementos de argumentação nos folhetos em forma de discurso.

As técnicas argumentativas usadas nos folders serão elucidadas e aplicadas no capítulo cinco. Os argumentos da estrutura do real, o vínculo 
causal e o conteúdo do argumento pragmático serão objeto de análise do capítulo seis; as relações entre os termos de uma analogia, assim como os seus efeitos serão analisados no sétimo capítulo; no capítulo oito, a ruptura, a expressão e os enunciados que incentivam a dissociação serão pontos de análise. O capítulo nove, por fim, abordará a interação, a apreciação e a ordem do discurso nos folhetos turísticos.

Em uma segunda vinculação, teremos o desenvolvimento das técnicas argumentativas constatadas nos folhetos, os argumentos baseados na estrutura do real dos folhetos e folders, as ligações que fundamentam a estrutura do real, as dissociações das noções e, por derradeiro, a análise da interação dos argumentos contidos nos folhetos e folders.

\section{METODOLOGIA DE PESQUISA}

O processo de pesquisa dar-se-á na aplicação do referencial teórico da Análise do Discurso de Chain Perelman, o que, em síntese, acontecerá da seguinte forma:

a) coleta de panfletos, folders e folhetos e/ou revistas publicitárias da área de turismo em agências de turismo do Distrito Federal;

b) análise desse material e, também, das imagens associativas aos textos presentes;

c) aplicação da teoria da Análise do Discurso para sugerir o nível de persuasão que esses textos exercem no leitor-turista. 
Os folhetos analisados foram, em grande parte, retirados da revista Carnival, a qual foi explorada significativamente como corpus importante para a realização de todo trabalho monográfico.

Em seguida, aplicou-se a teoria da Análise do Discurso de Perelman, o que, na verdade, aconteceu tanto com fragmentos dos textos-imagens como com as próprias sugestões que os folhetos pareciam oferecer ao leitor-turista.

Na seção de anexos, procurou-se evidenciar, de forma colorida, como a do original dos folhetos e das propagandas, a verdadeira estrutura textual que todos os folders pareciam mostrar aos consumidores de pacotes turísticos.

Dessa forma, percebeu-se, que, por meio da aplicação das técnicas argumentativas usadas nos folhetos, todos eles evidenciaram um alto grau de persuasão lingüística, haja vista que o próprio leitor-turista sempre hesitou em aceitar imediatamente as ofertas contidas nos folhetos de propagandas turísticas das revistas pesquisadas.

\section{CAPÍTULO I: OS NÍVEIS DA ARGUMENTAÇÃO NOS FOLHETOS TURÍSTICOS E O TURISMO COMO FENÔMENO DE MASSA}

1.1. Demonstração e argumentação nos folhetos e folders

Os primeiros folhetos e folders analisados tinham uma característica em comum: a diversão e a alegria associadas às ações dinâmicas da diversão perfeita. Portando, os títulos de cada folheto procuravam analogias que reunissem para o turista todos os atrativos necessários ao bom divertimento. Vejamos alguns:

(1) "Passe com a gente as melhores férias de sua vida".

(2) "A diversão perfeita para você".

(3) "Quase tudo está incluído em único preço".

(4) "O difícil mesmo é escolher". 
Como citado acima, infere-se que cada um desses títulos sugere uma sedução quase perfeita - exemplificado no item (2) com o adjetivo "perfeita" fazendo com que o turista, ao ler tais folhetos, não tenha dúvidas de que o seu investimento terá como retorno muita diversão, entretenimento e exuberância de produtos e serviços.

Nos itens (1), (3) e (4), temos uma comprovação de que realmente os serviços ofertados pela Carnival são imperdíveis, os melhores e, é claro, os mais baratos do mercado. Tudo isso perpassa uma questão chamada "sedução pela propaganda e, sobretudo, pela demonstração e pela argumentação".

Para tanto, Perelman (1996) afirma:

\begin{abstract}
Para bem expor as características particulares da argumentação e os problemas inerentes a seu estudo, nada como contrapô-la à concepção clássica da demonstração e, mais especialmente, à lógica forma que se limita ao exame dos meios de prova demonstrativos.
\end{abstract}

(Perelman, 1996: 15).

Dessa forma, todo o conteúdo dos folhetos analisados tem a função precípua de mostrar uma proposição por meio de elementos lingüísticos e visuais que possibilitem o convencimento do turista. Tal sedução dar-se-á principalmente se o turista-leitor vincular ações de seu cotidiano nas quais ele projeta o seu imaginário articulado com os seguintes pressupostos implícitos nos folders: escolha, praticidade, diversão e perfeição para aqueles que utilizarem os serviços da companhia Carnival. ${ }^{3}$

Com a intenção de ilustrar tal premissa, veja-se o que diz Perelman:

\footnotetext{
${ }^{3} \mathrm{~A}$ tradução para o Português é carnaval.
} 
Quando se trata de demonstrar uma proposição, basta indicar mediante quais procedimentos ela pode ser obtida como última expressão de uma seqüência dedutiva, cujos primeiros elementos são fornecidos por quem construiu o sistema axiomático dentro do qual se efetua a demonstração.

(Perelman, 1996: 16)

E ainda com o objetivo de provar a argumentação da sedução, tem-se mais um fragmento que procura sintetizar isso:

\begin{abstract}
Mas, quando se trata de argumentar, de influenciar, por meio do discurso, a intensidade de adesão de um auditório ${ }^{4}$ a certas teses, já não é possível monosprezar completamente, considerando-as irrelevantes, as condições psíquicas e sociais sem as quais a argumentação ficaria sem objeto ou sem efeito. Pois, toda argumentação visa à adesão das pessoas e, por isso mesmo, pressupõe a existência de um contato intelectual.
\end{abstract}

(Perelman, 1996:16)

1.2. O orador (sujeito) e o seu auditório (leitores) nos folhetos: uma metáfora possível.

Há alguns folhetos e folders que se referem ao espaço de tempo mais valioso para as pessoas que estão viajando: o lazer. Tal assunto toma dimensões impressionantes em nível de análise do discurso, ainda mais se levarmos em consideração os tipos de atividades sugeridas nos textos e nas imagens. Na revista pesquisada, o tópico "ATIVIDADES DIURNAS: dias sempre perfeitos" já sugere o esquecimento das horas, o início da diversão, associados com a liberdade do stress cotidiano.

Por isso, tornar-se-á evidente que a função referencial da linguagem fala por si só, transformando os folhetos em verdadeiros sedutores turísticos, ou seja, todo o auditório que Perelman (1996) caracteriza entra em um estado de puro

\footnotetext{
${ }^{4}$ Aqui entendido como o turista-leitor.
} 
convencimento e sedução por meio de imagens fantásticas e dignas de experimentação imediata. Para tanto, manifeste-se:

Os autores de comunicações ou de memórias científicas costumam pensar que thes basta relatar certas experiências, mencionar certos fatos, enunciar certo número de verdades, para suscitar infalivelmente o interesse de seus eventuais ouvintes ou leitores. Tal atitude resulta da ilusão, muito difundida em certos meios racionalistas e científicos, de que os fatos falam por si sós e imprimem uma marca indelével em todo espírito humano, cuja adesão forçam, sejam quais forem suas disposições.

(Perelman, 1996:20).

É por isso que constatamos tais experiências — como bem elucida Perelman - nos mais diversos tópicos de cada folheto. Logo, entradas como "Esqueça das horas ...", "Liberte-se do stress", "A diversão começa aqui" sugerem um alto grau de ilusão para o turista, ainda mais devido a grande combinação de cores e fatos ilustrados nos folhetos.

Destarte, é válido pensarmos que cada turista terá normalmente as mais diversificadas interpretações em relação as suas próprias preferências e gostos. Portanto, a conseqüência desse fato seria a ratificação de seu convencimento ao comprar o pacote. Então, a influência sobre o turista acabaria por confirmar a sua influência por conta da argumentação usada nos folhetos. Como exemplo ratificador desse pensamento, vejamos o seguinte trecho:

É por essa razão que, em matéria de retórica, parece-nos preferível definir o auditório como o conjunto daqueles que o orador quer influenciar com sua argumentação. Cada orador pensa, de uma forma mais ou menos consciente, naqueles que procura persuadir e que constituem o auditório ao qual se dirigem seus discursos.

(Perelman, 1996:22).

\subsection{Persuadir e convencer nos folhetos turísticos}


Em todas as revistas, folhetos e folders pesquisados, foi notória a função que primava por, primeiro, fazer o papel da sedução do turista. No tópico REFEIÇÕES, por exemplo, sempre verificou-se a persuasão textual aliada à precisão imagética, adicionada à sofisticação dos cabeçalhos textuais impecáveis.

Nesse enfoque, destacar-se-ão dois folhetos que têm os seguintes títulos: Um mundo de delícias culinárias", Jantar informal sempre que quiser e Muitas outras experiências deliciosas!. Torna-se óbvio que o convencimento acontecerá mais cedo ou mais tarde, mesmo se pensarmos no exagero de adjetivos, generalizações e metáforas sedutoras.

Nesse prisma, relatar-se-ão as palavras de Chain Perelman:

Para quem se preocupa com o resultado, persuadir é mais do que convencer, pois a convicção não passa da primeira fase que leva à ação. Para Rousseau, de nada adianta convencer uma criança se não sabe persuadi-la.

(Perelman, 1996:30).

Mesmo assim, há quem esteja preocupado com os resultados, resultando na seguinte assertiva:

Em contrapartida, para quem está preocupado com o caráter racional da adesão, convencer é mais do que persuadir. Aliás, ora essa característica racional da convicção depende dos meios utilizados, ora das faculdades às quais o orador se dirige. Para Pascal, ${ }^{5}$ o autômato é que é persuadido, e ele entende com isso o corpo, a imaginação, o sentimento, em suma, tudo quanto não é a razão. Com muita freqüência a persuasão será considerada uma transposição injustificada da demonstração.

(Perelman, 1996:30-31).

5 PASCAL, Bibl. de la Pléiade, Pensées, 470 (195), p. 961. 
Dessa forma, a culminância, por assim dizer, desse poder de persuasão/convencimento acontece com a seguinte assertiva:

\section{REFEIÇÕES}

que agradam a qualquer paladar (REVISTA CARNIVAL, 2003, p. 8)

Com o auxílio do verbo agradar associado com a semântica do generalizador discursivo "qualquer" faz com que o elemento "paladar" adquira um alto grau de persuasão sobre o turista que está lendo o folheto.

\subsection{A argumentação perante o leitor-turista}

Já fora dito que argumentar pressupõe convencer/persuadir alguém. Por isso, precisamos vincular certos paradoxos discursivos em detrimento dessa suposta persuasão do turista. É por causa desse fato que se desenvolveu a articulação entre argumentar vs. reação do leitor-turista.

Em vista de tal característica, perceber-se-á, mais uma vez, várias revistas com folhetos tendenciosamente voltados para uma linguagem cheia de imagens lingüísticas associadas até mesmo com os pressupostos da retórica. Veja-se esse trecho de um dos folhetos:

\section{NOITES}

à noite, tudo brilha. (REVISTA Carnival, 2003, p. 10)

Tornar-se lógico que o emissor da mensagem tem a clara intenção de estabelecer uma linha de raciocínio para que o turista procure acompanhar, influenciando-o nitidamente o desenvolvimento de seu discurso contínuo. Assim, confirma-se em Perelman (1996) a analogia entre dialética e retórica: 
É por isso que, segundo Quintiliano, por causa do aspecto mais denso da argumentação, Zenão comparava a dialética, como técnica do diálogo, a um punho fechado, enquanto a retórica Ihe parecia semelhante à mão aberta.

(Perelman, 1996:40).

É por isso que o diálogo torna-se tão importante para categorizar a análise do discurso dos folhetos de turismo, uma vez que o diálogo escrito:

Pressupõe, mais ainda do que o diálogo efetivo, que esse ouvinte encarne o auditório universal. ${ }^{6}$ E tal concepção parece justificada sobretudo quando se admite, como Platão, que existem no homem princípios internos coercivos que o guiam no desenvolvimento de seu pensamento.

(Perelman, 1996:41).

1.5. A argumentação, a educação e os folhetos turísticos

A educação e a argumentação têm um vínculo direto com os níveis de convencimento e sedução nos folhetos turísticos. Tal afirmativa desenvolve-se, primordialmente, pelo fato de que a leitura e a sua relação com a interpretação devem ser um dos primeiros indicadores de como pode ser o nível daquele leitor, especialmente se levarmos em consideração os seus diversos níveis de ansiedade projeção no que tange aos folhetos e folders.

Dessa forma, a relação que aqui se deseja estabelecer é a argumentação vs. propaganda, ambos associados à educação. Por isso, sabemos que a propaganda não está associada intrinsecamente com a educação, mas, por outro lado, sabe-se que a propaganda pressupõe níveis de argumentação. Sendo assim, torna-se viável que qualquer propaganda - inclusive a dos folhetos turísticos - envereda pelos caminhos do convencimento, principalmente se o objetivo final é seduzir para consumir, tornando, assim, o folheto em um produto agradável para o consumo do turista.

\footnotetext{
${ }^{6}$ A metáfora dos turistas como auditório universal.
} 
Sobre essa distinção entre educação e propaganda, veja-se o que diz Perelman:

A análise do gênero epidítico, de seu objeto e do papel que nele representa o orador, permitirá elucidar uma questão controvertida, que preocupa tantos teóricos atualmente: a distinção entre educação e propaganda. J. Driencourt, num livro recente e bem-documentado, analisa e rejeita numerosas tentativas para distinguir a educação da propaganda, e não chega a nenhuma conclusão satisfatória, por não situar seu estudo no âmbito de uma teoria geral da argumentação. Harold D. Lasswell, o especialista americano dessas questões, crê que o educador difere essencialmente do propagandista porque seu tema versa sobre matérias que não são, para seu auditório, objeto de controvérsia.

(Perelman, 1996:57).

Segundo o que afirma Perelman, pode-se inferir que educação e propaganda estão relativamente distantes porque ambas têm características diferentes em relação aos seus receptores. Aqui o leitor-turista só estabelece consonância com a influência que a argumentação exerce sobre ele em detrimento do resultado e dos níveis de convencimento estabelecidos pelo poder do texto escrito, o folheto e o folder.

Talvez seja necessário trabalhar alguns fragmentos dos folhetos selecionados com o objetivo ilustrar essa dicotomia entre educação, a propaganda:

1. Passe férias num resort flutuante — reserve com antecedência e economize

O seu agente de viagens poderá dar-Ihe informações sobre preços, disponibilidade e datas de saída do Fun Ship ${ }^{7}$ de sua preferência. Faça logo a sua reserva para garantir as acomodações e a data que the sejam convenientes. Lembre-se que, na maioria dos casos, quanto mais cedo você reservar, menor será o preço de seu cruzeiro.

\footnotetext{
7 Navio do Divertimento.
} 
(REVISTA Carnival, 2003, p. 12)

2. Feriados que incluem cruzeiro/vôo/hospedagem — diversão em dobro

A maioria de nossos passageiros internacionais faz coincidir seus cruzeiros Carnival com os feriados da América do Norte, México ou Caribe. A Carnival trabalha com os principais operadores de turismo em todo o mundo para oferecer atraentes pacotes de feriados (com tudo incluído), que conjugam cruzeiro, acomodações de hotel e vôos que partem das principais cidades internacionais.

(REVISTA Carnival, 2003, p. 12)

Como exposto acima, as propagandas explicitam verdades absolutas, quase inquestionáveis. Disso, infere-se que argumentação, em qualquer nível, enriquece qualquer propaganda, especialmente quando se tratar de propaganda turística, a qual o objetivo primordial é vender sonhos, idéias, lazer e visões paradisíacas.

Veja-se que a propaganda seguinte tem a função de, definitivamente, estabelecer intercâmbio entre as pessoas, associando isso com o lazer e o divertimento:

3. Uma experiência de grupo num "Fun Ship"

Os navios da Carnival têm capacidade para acomodar grupos de 16 a 2.750 pessoas em nosso estilo padrão, que é soberbo. Todos possuem espaçosas cabines e suítes de primeira classe para satisfazer às necessidades de seu grupo. Nossos salões de estar podem abrigar, com todo conforto, um grupo íntimo de 50 pessoas ou um grande grupo de 1.500 pessoas, e nossos cruzeiros possuem uma atmosfera ideal, 
que proporcionam vínculos de amizade. Reserve o seu cruzeiro com antecedência suficiente para garantir as acomodações e as datas de saída de sua preferência.

(REVISTA Carnival, 2003, p. 13)

Entretanto, além do lazer e do divertimento, temos também a presença de um elemento discursivo fundamental para o convencimento final do leitor-turista: a palavra "amizade". Tal vocábulo desempenha uma função primordial para levar o leitor à sedução final que é, na verdade, a compra do pacote da Carnival.

\subsection{Folhetos e envolvimento da argumentação}

Ao analisar folhetos com pacotes internacionais, percebemos que aquele "vínculo de amizade" explícito nos folders anteriores adiciona-se e elementos discursivos ainda bem articulados entre si. Essa articulação tem como objetivo senão estabelecer intercâmbios ainda muito mais amplos e rentáveis.

A palavra internacional presente nesses folhetos não perde a significação porque há, segundo a sedução da propaganda, programas de tradução simultânea que inevitavelmente agradam às pessoas que têm intenção de conhecer os navios da Carnival.

As fotos de cada folheto, associadas com a promessa de lazer e interação, ainda adicionadas com a futura idéia de conhecer pessoas novas e excitantes, incentivam qualquer pessoa a comprar o pacote de navios da Carnival.

Nesse ponto, o envolvimento com a propaganda dar-se-á, sobretudo, com as promessas já feitas nos folhetos, considerando que a argumentação é um exercício intelectual inteiramente desvinculado de qualquer preocupação de ordem prática.

(Perelman, 1996:66).

Tal ordem prática, segundo Perelman, traduz-se no embate semântico entre objetividade e subjetividade da leitura do folder e/ou folheto. Sobre o assunto, vejamos o que diz Perelman: 
A objetividade, quando atinente à argumentação, deve ser repensada, reinterpretada, para que possa ter sentido numa concepção que se recusa a separar uma afirmação da pessoa de quem a faz.

(Perelman, 1996:66)

Assim, essa dicotomia evidencia-se, claramente, nos folhetos, os quais procuram mostrar uma linguagem objetiva, direta e, é claro, convincente. A associação com as imagens também ajuda bastante nesse processo de convencimento argumentativo.

\subsection{O Turismo e suas definições}

A relação entre Turismo e folder é bastante significativa, uma vez que é por meio da propaganda e do convencimento que o leitor-turista opta por determinados pacotes do mercado. Assim, é interessante definirmos realmente o que vem a ser Turismo. Para tanto, citaremos o seguinte:

Os deslocamentos curtos e temporais das pessoas para destinos fora do lugar de residência e de trabalho e as atividades empreendidas durante a estada nesses destinos.

(Burkart e Medlik, 1981).

Nessa definição, conceitos como "deslocamentos fora do lugar de residência e de trabalho" introduz positivamente a conotação de viagem e férias/lazer, em contraposição à "residência" e ao "trabalho", mas, ao mesmo tempo, deixa fora conceitos modernos de turismo como são as viagens por motivos de negócios, com ou sem complementos de lazer ou as férias em segundas residências. É também criticável o termo vago "deslocamento curto".

O turismo como matéria de estudos universitários começou a interessar no período compreendido entre as duas grandes guerras mundiais (1919-1938). Durante esse período, economistas europeus começaram a publicar os primeiros 
trabalhos, destacando a chamada Escola de Berlim com autores como Glucksmann, Schwinck ou Bormann.

Em 1942, os professores da Universidade de Berna, da Suíça, W. Hunziker e K. Krapf, definiram o turismo como: "A soma de fenômenos e de relações que surgem das viagens e das estâncias dos não residentes, desde que não estejam ligados a uma residência permanente nem a uma atividade remunerada".

Mathieson y Wall (1982), por sua vez, utilizaram uma definição muito semelhante à anterior ainda que com algumas modificações: "Turismo é o movimento provisório das pessoas, por períodos inferiores a um ano, para destinos fora do lugar de residência e de trabalho, as atividades empreendidas durante a estada e as facilidades são criadas para satisfazer as necessidades dos turistas". Como se pode observar, destaca o caráter temporário da atividade turística ao introduzir o termo "período inferior a um ano". Também introduzem duas importantes inovações: de um lado a perspectiva da oferta quando mencionam as "facilidades criadas"; de outro, introduzem na definição o fundamento de toda atividade turística: a satisfação das necessidades dos leitores-turistas e/ou clientes.

Por fim, há que se destacar a definição que foi adotada pela Organização Mundial de Turismo (1994), que une todos os pontos positivos das expostas anteriormente e, por sua vez, formaliza os aspectos da atividade turística. Vejamos a definição:

O turismo compreende as atividades que realizam as pessoas durante as viagens e estadas em lugares diferentes ao seu entorno habitual, por um período consecutivo inferior a um ano, com finalidade de lazer, negócios ou outras.

Trata-se de uma definição ampla e flexível que concretiza as características mais importantes do turismo. São elas:

- Introdução dos possíveis elementos motivadores de viagem: lazer, negócios ou outros; 
- Nota temporária do período por um ano, período realmente amplo, máximo se comparado com o tempo normal de duração dos vistos de viagem para turismo dados pelos governos - três meses — ou com a periodicidade prevista por algumas legislações para delimitar o que se considera habitual — seis meses;

- Delimitação da atividade desenvolvida antes e durante o período de estada;

- Localização da atividade turística como a atividade realizada "fora do seu entorno habitual" .

\subsection{Os tipos de turismo}

As modalidades turísticas existem porque há valores inerentes às formas convencionais e às realidades intrínsecas da própria maneira de ser do turismo. Dessa forma, segundo José Vicente de Andrade (2001:61-80), existem os seguintes:

- TURISMO DE FÉRIAS: O fenômeno existe de forma habitual e espontânea ou por prescrição legal. São dias seguidos caracterizados pela cessação do trabalho habitual, destinados ao repouso a que os trabalhadores e estudantes fazem jus, ou costumam usufruir, a cada ciclo anual de atividade.

- TURISMO BALNEÁRIO: É o tipo que possui os melhores registros de sua antiguidade, sua utilização e seu valor, pois, ainda hoje, existem alguns mosaicos romanos anteriores à era cristã com desenhos de pessoas em trajes sumários, brincando e jogando bola numa praia; importantes documentos que atestam tanto a prática dos esportes quanto a utilização balneária de orla marítima.

- TURISMO MONTANHÊS: As montanhas fascinam a todas as pessoas de todas as idades e classes sociais, sem distinção de níveis de inteligência e de cultura. Quem nelas vive não deseja delas se afastar; quem delas está distante deseja vê-las, senti-las e por elas caminhar. Embora acidentes físicos 
da conformação terrestre, são símbolos dos estímulos motivadores das mais nobres reações de otimismo, de garra, de persistência, de idealismo e de libertação, pois apresentam-se como irrecusáveis convites para que a humanidade olhe e caminhe sempre mais para o alto, para o melhor, para o mais nobre.

- TURISMO DE REPOUSO: É mais estado de espírito que característica de disponibilidade física ao nada fazer. Efetua-se pela suspensão ou cessação do trabalho por determinado período que, geralmente, coincide com a duração de férias, de feriados prolongados ou mesmo de fins de semana, salvo casos de necessidades maiores, que levam as pessoas a cessar suas atividades em qualquer período.

- TURISMO CULTURAL: A experiência humana e todas as suas manifestações se constituem em fator cultural, mas, por coerência e respeito às finalidades que são meios classificatórios do turismo, a expressão turismo cultural possui conotação restritiva e abrange exclusivamente as atividades que se efetuam através de deslocamentos para a satisfação de objetivos de encontro com emoções artísticas, científicas, de formação e de informação nos diversos ramos existentes.

- TURISMO CIENTÍfICO: O interesse ou a necessidade de realização de estudos e pesquisas é o elemento motivador do turismo científico, que se caracteriza pelos interesses pessoais dos turistas ou visitantes para com as fontes e os objetos das ciências.

- TURISMO DE CONGRESSO: Por turismo de congresso ou turismo de convenções, entende-se o conjunto de atividades exercidas pelas pessoas que viajam a fim de participar de congressos, convenções, assembléias, simpósios, seminários, reuniões, ciclos, sínodos, concílios e demais encontros que visam ao estudo de alternativas, de dimensionamentos ou de interesses de determinada categoria profissional, associação, clube, crença religiosa, 
corrente científica ou outra organização com objetivos nos campos científicos, técnicos e religiosos.

- TURISMO DE NEGÓCIOS: É o conjunto de atividades de viagem, de hospedagem, de alimentação e de lazer praticado por quem viaja a negócios referentes aos diversos setores da atividade comercial ou industrial ou para conhecer mercados, estabelecer contatos, firmar convênios, treinar novas tecnologias, vender ou comprar bens ou serviços.

- TURISMO DESPORTIVO: Todas as atividades específicas de viagens com vistas ao acompanhamento, desempenho e participação exercidos em eventos desportivos, no país e/ou no exterior, classificam-se e denominam-se como turismo desportivo.

- TURISMO DE SAÚDE: O conjunto de atividades turísticas que as pessoas exercem na procura de meios de manutenção ou de aquisição de bom funcionamento e sanidade de seu físico e de seu psiquismo chama-se turismo de saúde, turismo de tratamento ou turismo terápico.

- TURISMO RELIGIOSO: O conjunto de atividades com utilização parcial ou total de equipamentos e a realização de visitas a receptivos que expressam sentimentos místicos ou suscitam a fé, a esperança e a caridade aos crentes ou pessoas vinculadas a religiões, denomina-se turismo religioso.

\subsection{As formas de turismo}

Como atividade humana, o turismo supõe determinado nível mínimo de estrutura organizacional fundamentada nas necessidades ou conveniências expressas pelas formas, através das quais o fenômeno se efetiva, e nas motivações manifestas que levam as pessoas a agir de formas determinadas, em modalidades diversas e tipos distintos.

Por isso, mais uma vez, segundo José Vicente de Andrade (2001:82-86), temos as seguintes: 
- TURISMO INDIVIDUAL: Denomina-se turismo individual todo o conjunto de atividades necessárias ao planejamento e à execução de viagens, sem o concurso de agência de viagens ou de qualquer outra entidade de natureza turística.

- TURISMO ORGANIZADO: Chama-se turismo organizado o conjunto de atividades turísticas programado, administrado e executado por agências de viagens, associações, entidades de classe, clubes ou por qualquer outra organização que envolva grupos de pessoas.

- TURISMO SOCIAL: A forma especial de viagem, hospedagem, alimentação, serviços e lazer organizada para pessoas de camadas sociais, cujas rendas, sem a ajuda de terceiros, não Ihes permitiriam a programação, denomina-se turismo social.

- TURISMO INTENSIVO: Denomina-se turismo intensivo ou turismo estável o conjunto de programações turísticas em que a pessoas permanecem baseadas ou hospedadas em um receptivo único, ainda que efetuem excursões e passeios a outros lugares.

- TURISMO EXTENSIVO: Por turismo extensivo de longo prazo, entende-se a hospedagem e o conjunto de atividades em um mesmo núcleo, com a duração de pelo menos três semanas.

- TURISMO ITINERANTE: Quando a programação turística se compõe de visitas ao maior número possível de núcleos receptivos, em uma viagem única, com estada curta em cada um dos locais visitados, dá-se o nome de turismo itinerante, porque se forma de uma série de permanências ou estadas em lugares diversos.

CAPÍTULO II: O PONTO DE PARTIDA DA ARGUMENTAÇÃO DOS FOLHETOS E FOLDERS TURÍSTICOS

\subsection{As premissas da argumentação}

Em turismo, toda argumentação precisa de uma premissa que se constitui como fundamental para que o acordo se concretize. É verdade que miscigenação 
entre texto e foto engrandece substancialmente o nível de sedução do leitor, ainda mais se pensarmos em termos de lazer e agradabilidade.

Por isso, devemos elucidar que, entre todos os folhetos de revistas analisados, praticamente a premissa de argumentação era, de início, o convite e, depois, a aceitação imediata desse convite, resultando, implicitamente, no acordo, a qual a propaganda esforça-se por estabelecer. Assim, na página 16-18, de uma das revistas analisadas, temos as seguintes propagandas:

1. 30 anos de Diversão!

A Carnival está comemorando 30 Anos de Diversão mudando para melhor. Agora oferecemos mais opções, mais pontos de partida e mais destinos exóticos. Nosso comprometimento é oferecer as melhores opções de férias e tarifas acessíveis fazemos de tudo para você aproveitar o melhor de um cruzeiro. Estamos aumentando nossa frota, o número de pontos de partida e de destinos. A melhor maneira de se chegar a praias douradas e outras maravilhas do México e do Caribe é em um cruzeiro da Carnival!

(REVISTA Carnival, 2003, p. 16)

2. Magia das ilhas

Realize o sonho de conhecer a Riviera Mexicana, verdadeiro caleidoscópio de culturas e paisagens. Aproveite seus passeios em terra para visitar alegres mercados ricos em artesanato local; aqui você encontra uma mistura de tradição e cultura em tecidos coloridos. Além desses passeios, você pode ainda escolher entre as várias opções de excursões exclusivas.

(REVISTA Carnival, 2003, p. 17).

Como foi dito anteriormente, as premissas da argumentação associam bemestar com oportunidade, ou seja, no folder 30 ANOS DE DIVERSÃO!, percebe-se a vinculação do acordo entre a comemoração do Carnival com o prazer em 
oferecer os serviços turísticos, exemplificando-se com os pontos de partida e os destinos exóticos que o anúncio elucida.

Em MAGIA DA ILHAS, percebe-se o acordo em conhecer novas culturas e paisagens, complementadas com a mistura de tradições, além, naturalmente, da diversidade de tecidos diferentes. Por isso, Perelman afirma:

\begin{abstract}
A concepção que as pessoas têm do real pode, em largos limites, variar conforme as opiniões filosóficas professadas. Entretanto, na argumentação, tudo o que se presume versar sobre o real se caracteriza por uma pretensão de validade para o auditório universal. Em contrapartida, o que versa sobre o preferível, o que nos determina as escolhas e não é conforme a uma realidade preexistente, será ligado a um ponto de vista determinado que só podemos identificar com o de um auditório particular, por mais amplo que seja.
\end{abstract}

(Perelman, 1996:74)

A vinculação com O LUGAR DA DIVERSÃo Que fazer em 2003 deve seguir a mesma premissa que Perelman estabeleceu acima com o objetivo principal de concretizar o acordo entre o leitor-turista e a agência veiculadora da propaganda.

2.2. Os fatos e as verdades nas entrelinhas dos folhetos e folders

Em relação aos fatos apresentados, é mister analisar que todos eles, em geral, apresentam-se ao leitor-turista como verdadeiros e inquestionáveis. Apesar de que fatos e verdades, em análise do discurso, possuem significações ligeiramente diferentes e, portanto, sujeitos a inferições distintas.

Por isso, em DESTINOS EXóTICOS Maior variedade, mais destinos numa palavra, mais diversão!(Revista Carnival, pág. 18-20), temos mares, árvores, ambientes gelados e natureza simbolizando fatos que levam os turistas à verdade absoluta: o consumo do pacote ofertado. Pensando nessa distinção entre fatos e verdades, ver-se-á o raciocínio de Perelman:

Entre os objetos de acordo pertencentes ao real distinguiremos, de um lado, os fatos e verdades, de outros, as presunções. Não seria possível nem conforme ao nosso 
propósito dar do fato uma definição que permita, em todos os tempos e em todos os lugares, classificar este ou aquele dado concreto como sendo um fato. Cumpre-nos, ao contrário, insistir em que, na argumentação, a noção de "fato" é caracterizada unicamente pela idéia que se tem de certo gênero de acordos a respeito de certos dados: os que se referem a uma realidade objetiva e designariam, em última análise, citando $\mathrm{H}$. Poincaré, "o que é comum a vários entre pensantes e poderia ser comum a todos.

(Perelman, 1996:75)

Assim, os fatos e as verdades nos folhetos também se distinguem mutuamente, uma vez que ambos têm, por sua vez, objetivos diferentes em relação ao nível de convencimento do leitor-turista.

2.3. Os valores abstratos e os valores concretos nos folhetos e folders

Os folhetos analisados tiveram características bastante diferentes quando comparados aos valores dos turistas. O próprio Perelman trata a questão com muito cuidado por ela não apresentar definição fácil e não ser passível de uma boa compreensão. Em relação à análise do discurso, o que temos não se configura como algo muito significativo e novo.

Todavia, há grandes possibilidades de enveredarmos para as explicações discursivas em relação aos folders e folhetos coletados. Em um dos selecionados, temos:

1. SUL DA FLÓRIDA Miami, Coconut Grove, Key West, Fort Lauderdale e O Everglades

2. Visite a Riviera de Miami

Quilômetros de soberbo mar turquesa quebrando sobre as brancas areias da praia. Gente bonita e vibrante vivendo ao ritmo latino. Esta é a magia de Miami. Um horizonte iluminado em néon, tesouros arquitetônicos do Art Déco, hotéis cinco estrelas, restaurantes de classe internacional e casas noturnas da 
moda, tudo isso pulsa no coração de South Beach. Alguns quilômetros mais ao sul, fica o popular Coconut Grove, onde você pode percorrer as calçadas repletas de gente, lojas de artesanato, galerias exclusivas e jantar em pitorescos cafés ao ar livre.

(REVISTA Carnival, 2003, pp. 22-23)

3. Extasie os seus sentidos

Ft. Lauderdale é a "Veneza da América", com mais de 480 quilômetros de canais navegáveis. Visite o Museum of Discovery and Science e o Broward Center for the Performing Arts, famoso pela sua programação de música, dança, arte e teatro. Passeie pelo Lãs Olas Boulevard, com sua incrível gama de restaurantes finos e lojas exclusivas. Conclua sua visita a Fort Lauderdale passando um dia no Sawgrass Mills, percorrendo algumas das suas mais de 300 lojas de ponta de estoque.

(REVISTA Carnival, 2003, p. 23)

Podemos observar que os exemplos 2 e 3 constituem legítimos casos de argumentação sobre valores. Apesar de o exemplo 1 ser um tipo de descrição neologística ${ }^{8}$, também inferimos que os valores, sobretudo os econômicos, têm uma interferência significativa nas escolhas dos turistas.

Em "Visite a Riviera de Miami", ver-se-á uma clara valorização do concreto discursivo do que o abstrato de cada leitor-turista. Uma das razões é, por exemplo, a projeção do próprio prazer individual, tendo as fotografias acima dos textos ajudado sobremaneira para que o turista pudesse decidir qual o pacote escolhido.

Não é à-toa que Chain Perelman tentou definir ambos os tipos de valores discursivos:

A argumentação sobre os valores necessita de uma distinção, que julgamos fundamental e foi muito menosprezada, entre valores abstratos, tais como a

${ }^{8}$ Relativo ao neologismo em Língua Portuguesa. 
justiça ou a veracidade, e os valores concretos, tais como a França ou a Igreja. O valor concreto é o que se vincula a um ente vivo, a um grupo determinado, a um objeto particular, quando os examinamos em sua unicidade. A valorização do concreto e o valor conferido ao único estão estreitamente ligados: desvelar o caráter único de alguma coisa é valoriza-la pelo próprio fato. Os escritores românticos, revelando-nos o caráter único de certos seres, de certos grupos, de certos momentos históricos, provocaram, até no pensamento filosófico, uma reação contra o racionalismo abstrato, reação que se assinala pela situação eminente conferida à pessoa humana, valor concreto por excelência.

(Perelman, 1996:87)

Assim, vemos que os níveis argumentativos baseiam-se em ambos os processos: o abstrato e o concreto. Se voltarmos aos três textos dos folhetos, veremos que, no caso do "Extasie os seus sentidos", a "Veneza da América" assume um valor abstrato muito grande, passando, logo depois, ao um valor concreto considerável.

A partir dessa premissa, é possível afirmamos que a argumentação no folder turístico também precisa tomar como modelo tal preceito, fundamentalmente porque o discurso é constituído de valores, não importando muito quais eles sejam.

Para ratificar isso, mencionamos a seguinte assertiva:

A argumentação se baseia, conforme as circunstâncias, ora nos valores abstratos, ora nos valores concretos; às vezes, é difícil perceber o papel representado por uns e outros. Quando dizemos que os homens são iguais porque são filhos de um mesmo Deus, parecemos estear-nos num valor concreto para encontrar um valor abstrato, o da igualdade; mas poderíamos dizer também que se trata, nesse caso, apenas do valor abstrato que se expressa recorrendo, por analogia, a uma relação concreta; apesar do emprego do porque, o ponto de partida estaria no valor abstrato. 
Como vimos nas palavras de Perelman, a argumentação não é algo isolado, sem contexto definido. Antes de mais nada, ela é, no âmbito do turismo, algo essencial e imprescindível no processo discursivo, haja vista que sem ela não haveria, talvez, convencimento ou sedução por parte do leitor-turista.

\subsection{As hierarquias discursivas nos folhetos e folders}

Em análise do discurso, especialmente a de Perelman, as hierarquias estão inter-relacionadas com os valores ora aqui já analisados. Assim, os valores abstratos e concretos complementam as hierarquias existentes, por exemplo, na superioridade do homem sobre os animais e dos deuses sobre os homens.

Dessa forma, poderíamos inferir que a argumentação por hierarquia acontece também nas temáticas textuais e visuais dos folhetos em turismo. É por isso que em

\section{FASCINATION Cruzeiros de 3 e 4 dias pelo Caribe, saindo de Miami (REVISTA}

Carnival, p.24) a hierarquia dos valores abstratos, ou seja, a projeção mental do passeio, o divertimento e a alegria, acaba predominando sobre os outros valores que o ser humanos costuma dar importância.

Em outras linhas, o discurso também é fortemente influenciado pelas estratificações realizadas na sociedade, ainda mais se elas se referirem à dinamização escrita dos folhetos de turismo.

A respeito dessa hierarquização, Perelman afirma:

A argumentação se esteia não só nos valores, abstratos e concretos, mas também nas hierarquias, tais como a superioridade dos homens sobre os animais, dos deuses sobre os homens. Por certo essas hierarquias seriam justificáveis em virtude de valores, porém, mais comumente, só se tratará de buscar-lhes um fundamento quando for o caso de defende-las; amiúde, aliás, ficarão implícitas, tal como a hierarquia entre pessoas e coisas na passagem em que Scheler, tendo mostrado que os valores podem hierarquizar-se de acordo com seus suportes, concluí que os valores relativos às pessoas são, por sua própria natureza, superiores aos valores relativos às coisas.

(Perelman, 1996:90) 
Nesse fase de análise, percebe-se que os folhetos da páginas 24 e 25, da revista Carnival, mostram-se em disposição hierárquica, haja vista que dois dos folhetos têm título (cf. Recordações para a vida toda e Percorra o Hollywood Boulevard). Por outro lado, ainda nessa página, os outros dois folhetos não possuem título, mostrando, assim, que o próprio valor simbólico assumiu a projeção da realidade concreta, de acordo com as características da hierarquização.

Com base nisso, temos:

As hierarquias de valores são, decerto, mais importantes do ponto de vista da estrutura de uma argumentação do que os próprios valores. Com efeito, a maior parte destes são comuns a um grande número de auditórios. O que caracteriza cada auditório é menos os valores que admite do que o modo com os hierarquiza.

(Perelman, 1996:92)

Em "Percorra a Hollywood Boulevard", tem-se um folheto que seduz mais pela capacidade vocabular do que pela riqueza fotográfica. A metáfora do pôr-do-sol com o próprio FASCINATION desperta-nos para uma sedução muito mais propiciada pela grande riqueza de descrições e pela impressionante leitura argumentativa em relação aos nomes próprios.

\subsection{A análise do discurso}

De acordo com Eni (2000:12), há muitas maneiras de estudar-se a linguagem: concentrando nossa atenção sobre a língua enquanto sistema de signos ou como sistema de regras formais, temos então a Lingüística; ou como normas de bem dizer, por exemplo, e temos a Gramática normativa. Além disso, a própria palavra gramática como a palavra língua podem significar coisas muitos diferentes, por isso as gramáticas e a maneira de se estudar a língua são diferentes em diferentes épocas, em distintas tendências e em autores diversos. Pois é justamente pensando que há muitas maneiras de se significar que os estudiosos começaram a se 
interessar pela linguagem de uma maneira particular que é a que deu origem à Análise do Discurso.

A Análise do Discurso, como seu próprio nome indica, não trata da língua, não trata da gramática, embora todas essas coisas Ihe interessem. Ela trata do discurso. E a palavra discurso, etimologicamente, tem em si a idéia de curso, de percurso, de correr por, de movimento. O discurso é assim a palavra em movimento, prática de linguagem: com o estudo do discurso observa-se o homem falando.

$\mathrm{Na}$ análise do discurso, procura-se compreender a língua fazendo sentido, enquanto trabalho simbólico, parte do trabalho social geral, constitutivo do homem e da sua história.

Por esse tipo de estudo se pode conhecer melhor aquilo que faz do homem um ser especial com sua capacidade de significar e significar-se. A Análise do Discurso concebe a linguagem como mediação necessária entre o homem e a realidade natural e social. Essa mediação, que é o discurso, torna possível tanto a permanência e a continuidade quanto o deslocamento e a transformação do homem e da realidade em que ele vive. O trabalho simbólico do discurso está na base da produção da existência humana.

Assim, a primeira coisa a se observar é que a Análise de discurso não trabalho com a língua enquanto um sistema abstrato, mas com a língua no mundo, com maneiras de significar, com homens falando, considerando a produção de sentidos enquanto parte de suas vidas, seja enquanto sujeitos, seja enquanto membros de uma determinada forma de sociedade.

Dessa forma, levando em conta o homem na sua história, considera os processos e as condições de produção da linguagem, pela análise da relação estabelecida pela língua com os sujeitos que a falam e as situações em que se produz o dizer. Desse modo, para encontrar as regularidades da linguagem em sua produção, o analista de discurso relaciona a linguagem à sua exterioridade.

Tendo em vista esta finalidade, ele articula de modo particular conhecimentos do campo das Ciências Sociais e do domínio da Lingüística. Fundando-se em uma 
reflexão sobre a história epistemologia e da filosofia do conhecimento empírico, essa articulação objetiva a transformação da prática das ciências sociais e também a dos estudos da linguagem e, em particular, ao texto escrito da propaganda turística.

Em uma proposta em que o político e o simbólico se confrontam, essa nova forma de conhecimento coloca questões para a Lingüística, interpelando-a pela historicidade que ela apaga, do mesmo modo quem coloca questões para as Ciências Sociais, interrogando a transparência da linguagem sobre a qual elas se assentam. Dessa maneira, os estudos discursivos visam pensar o sentido dimensionado no tempo e no espaço das práticas do homem, descentrando a noção de sujeito e relativizando a autonomia do objeto da Lingüística.

Nessa confluência, a Análise do Discurso critica a prática das Ciências Sociais e a da Lingüística, refletindo sobre a maneira como a linguagem está materializada na ideologia e como a ideologia se manifesta na língua. Conseqüentemente, o discurso é o lugar em que se pode observar essa relação entre língua e ideologia, compreendendo-se como a língua produz sentidos por/para os sujeitos.

Embora a Análise de Discurso, que toma o discurso como seu objeto próprio, tenha seu início nos anos 60 do século XX, o estudo do que lhe interessa a ela - o da língua funcionando para a produção de sentidos e que permite analisar unidades além da frase, ou seja, o texto - já se apresentara de forma não sistemática em diferentes épocas e segundo diferentes perspectivas.

Sem pensarmos na Antiguidade e nos estudos retóricos, temos estudos do texto, em sua materialidade lingüística, em M. Bréal, por exemplo, no século XIX, com sua semântica histórica. Situando-se no século $X X$, temos os estudos dos formalistas russos (anos 20/30), que já pressentiam no texto uma estrutura. Embora o interesse dos formalistas fosse sobretudo literário, os seus trabalhos, buscando uma lógica interna do texto, prenunciavam uma análise que não era a análise do texto, prenunciavam uma análise que não era a análise do conteúdo, maneira tradicional de abordagem. 
Ainda em termos de precursores, outra forma de análise bem-sucedida, que já pesquisava o texto, é a do estruturalista americano Z. Harris (anos 50). Com seu método distribucional, ele consegue livrar a análise do texto do viés conteudista mas, para fazê-lo, reduz o texto a uma frase longa. Isto é, caracteriza sua prática teórica no interior do que chamamos isomorfismo: estende o mesmo método de análise de unidades menores (morfemas, frases) para unidades maiores (texto) e procede a uma análise lingüística do texto como o faz na instância da frase, perdendo dele aquilo que ele tem de específico. Como sabemos, o texto não é apenas uma frase longa ou uma soma de frases. Ele é uma totalidade com sua qualidade particular, com sua natureza específica.

Nos anos 60, a Análise do Discurso constitui o espaço de questões criadas pela relação entre três domínios disciplinares que são ao mesmo tempo uma ruptura com o século XIX: a Lingüística, o Marxismo e a Psicanálise.

A Lingüística constitui-se pela afirmação da não-transparência da linguagem: ela tem seu objeto próprio, a língua, que tem sua ordem própria. Essa afirmação é fundamental para a Análise do Discurso, que procura mostrar que a relação linguagem-pensamento-mundo não é unívoca, não é uma relação direta que se faz termo-a-termo, isto é, não se passa diretamente de um a outro. Cada um tem sua especificidade.

Por outro lado, a Análise do Discurso pressupõe o legado do materialismo histórico, isto é, o de que há um real da história de tal forma que o homem faz história mas esta também não lhe é transparente. Daí, conjugando a língua com a história na produção de sentidos, esses estudos do discurso trabalham no que se vai chamar a forma material (não abstrata como a da Lingüística) que é a forma encarnada na história para produzir sentidos: esta forma é portanto lingüísticohistórica.

Nos estudos discursivos, não se separam forma e conteúdo e procura-se compreender a língua não só como uma estrutura, mas sobretudo como acontecimento. Reunindo estrutura e acontecimento a forma material é vista como o 
acontecimento do significante (língua) em um sujeito afetado pela história. Aí entra então a contribuição da Psicanálise, com o deslocamento da noção de homem para a de sujeito. Este, por sua vez, se constitui na relação com o simbólico, na história.

Assim, para a Análise do Discurso:

a. a língua tem sua ordem própria, mas só é relativamente autônoma (distinguindo-se da Lingüística, ela reintroduz a noção de sujeito e de situação na análise da linguagem);

b. a história tem seu real afetado pelo simbólico (os fatos reclamam sentidos);

c. o sujeito de linguagem é descentrado, pois é afetado pelo real da língua e também pelo real da história, não tendo o controle sobre o modo com elas o afetam. Isso redunda em dizer que o sujeito discursivo funciona pelo inconsciente e pela ideologia.

Desse modo, se a Análise do Discurso é herdeira das três regiões de acontecimento - Psicanálise, Lingüística, Marxismo — não o é de modo servil e trabalha uma opção - a de discurso - que não se reduz ao objeto da Lingüística, nem se deixa absorver pela Teoria Marxista e tampouco corresponde ao que teoriza a Psicanálise. Interroga a Lingüística pela historicidade que ela deixa de lado, questiona o Materialismo perguntando pelo simbólico e se demarca da Psicanálise pelo modo como, considerando a historicidade, trabalha a ideologia como materialmente relacionada ao inconsciente sem ser absorvida por ele. 


\subsection{A propaganda e a publicidade}

Harris e Seldon (1962:40) definem a propaganda como notícia pública "destinada a divulgar informações com vistas à promoção de vendas de bens e serviços negociáveis". Como se verá, esta definição abrange tanto a propaganda industrial como a propaganda ao consumidor, em que o anunciante é uma empresa que não visa a outras empresas, mas os consumidores individuais. Os dois participantes da situação de comunicação definida pela propaganda ao consumidor são, portanto, desiguais no que concerne ao interesse e ao conhecimento sobre o produto anunciado (cf. Wight, 1972:9, "compradores amadores em face de um vendedor profissional").

Assim, para que existe a propaganda e por que ela tem de ser persuasiva? Por que os anunciantes não informam simplesmente os consumidores sobre a disponibilidade e o preço da mercadoria e os deixam resolver se compram ou não? A resposta às duas questões está nas condições sociais que tornam a propaganda possível e nas quais se efetua o consumo.

$\mathrm{Na}$ medida em que o aparelho de produção de uma sociedade não esteja suficientemente desenvolvido para satisfazer mais que as meras necessidades materiais de sua população, é claro que não hão lugar para a propaganda. Para que esta tenha algum sentido, pelo menos um segmento da população terá que viver acima do nível da subsistência: no momento em que isso acontece, os produtores de bens materialmente "desnecessários" devem fazer alguma coisa para que as pessoas queiram adquiri-los.

A propaganda só conheceu uma verdadeira expansão, contudo, no final do século XIX. A tecnologia e as técnicas de produção em massa já tinham atingido um 
nível de desenvolvimento em que um maior número de empresas produzia mercadorias de qualidade mais ou menos igual a preços mais ou menos iguais. Com isso, veio a superprodução e a subdemanda (Turner, 1965:132-4), tornando-se necessário estimular o mercado - de modo que a técnica publicitária mudou da proclamação para a persuasão. Ao mesmo tempo, a alfabetização se alastrara mais e o primeiro jornal a ter boa parte da sua renda derivada da publicidade, o Daily Mail, foi lançado nesse período. Por fim, nos últimos anos do século passado a propaganda se tornou uma área profissional definida, com a fundação das primeiras agências.

Diante do exposto, o papel de propaganda consiste em influenciar os consumidores no sentido da aquisição do produto; vale, porém, o princípio segundo o qual o publicitário não é capaz de criar novas necessidades, mas apenas de retardar ou acelerar as tendências existentes (Brown, 1963:77). Portanto, se as agências conhecerem o seu ofício, é de esperar que a propaganda reflita muito de perto as tendências do momento e os sistemas de valores da sociedade. Contudo, os compradores em potencial de motocicletas devem diferir de uma dona-de-casa na escolha de artigos de cutelaria, o que se refletirá, presumivelmente, nos valores representados em cada caso. Em outras palavras, é de esperar que o método de persuasão varie conforme o produto e conforme a idade, o sexo e a classe social do provável comprador. Por essa razão, é importante que todo estudo sobre a propaganda abranja a gama mais ampla possível de publicações, embora se considere razoável a exclusão das revistas especializadas. 


\title{
CAPÍTULO III: ADAPTAÇÃO DOS FOLHETOS E FOLDERS COM VISTAS À ARGUMENTAÇÃO E A RETÓRICA
}

\subsection{A interpretação dos folhetos analisados}

Muitos dos folhetos e folders analisados possuíam dados que indiretamente levavam os turistas a interpretação que toda fotografia, associada a um texto, exerce sobre um leitor: o convencimento. Dessa forma, não haveria possibilidade de o leitor, por exemplo, atribuir-Ihes conotações negativas e pejorativas. Para exemplificar tal fenômeno, temos:

\begin{abstract}
O estudo da argumentação nos obriga, de fato, a levar em conta não só a seleção dos dados, mas igualmente o modo como são interpretados, o significado que se escolheu atribuir-Ihes. É na medida em que ela constitui uma escolha, consciente ou inconsciente, entre vários modos de significação, que a interpretação pode ser distinguida dos dados que interpretamos e oposta a estes.
\end{abstract}

(Perelman, 1996:137)

Com o objetivo de ilustrar tal afirmação de Perelman, vejamos alguns textos de folhetos:

1. Explore o azul-turquesa do mar

2.

Programamos mais algumas aventuras de quatro e cinco dias pelo Caribe para você. Navegue de quinta a segunda-feira, num longo fim de semana cheio de diversões, pela histórica Key West, na Flórida, e Playa Del Carmen/Cozumel, ou pela Península de Yucatán, no México. Se preferir, opte por um cruzeiro de 5 dias, saindo numa Segunda-feira, para curtir a tranqüilidade da Grand Cayman ou apreciar a fervilhante Caliça. Embarque num sábado e viva os prazeres de Grand Cayman e de Ocho Rios.

(REVISTA Carnival, 2003, p. 26) 
3. Dê asas à sua imaginação

No momento que pisar a bordo, você será transportado para lugares cheios de magia com os quais apenas sonhou. Percorra o passeio e aprecie o projeto caprichoso de suas esfinges douradas e criaturas mitológicas, que ladeiam o convés. Tome um drinque exótico nos paraísos de fábula dos salões ShangriLa e Xanadu. Satisfaça sua avidez pela dança no ambiente altamente criativo do Illusions Dance Club ou descubra que tudo que reluz é ouro no El Dorado Casino".

(REVISTA Carnival, 2003, pp. 26-28)

Nesse caso, o texto 1 faz uma bela analogia com a sensibilidade das cores associada à grandeza do mar. No texto 2, já temos o imaginário propiciando a "viagem" ao reino do fantástico, o que acaba se configurando no passeio ao inusitado e completamente desconhecido. A volta à era mitológica e a associação com o Cassino dão ao leitor-turista uma interpretação da mais absoluta plenitude turística ao adentrar o navio.

3.2. A interpretação do discurso nos folhetos e folders e seus relativos problemas

O primeiro tópico problemático que colocaríamos é a questão da ambigüidade lingüística. Todos os folders analisados tiveram uma ligeira relação com a ambigüidade no sentido de gerar expectativa e desejos no leitor-turista. Por isso, as figuras de linguagem usadas em alguns títulos (cf. "Ouça o apelo do mar", Revista Carnival, p. 28) já mostram muito bem esse nível de influência na decisão do turista. A fim de ilustrar tal associação, veremos: 


\section{"Viva a emoção"}

Aproveite tudo que o Caribe tem a oferecer, na sua aventura de 7 dias. Sinta o fascínio do mar ao entrar no Oceanic Hall do CARNIVAL VICTORY, o ártrio principal do navio, de 9 andares de altura, com fantásticos elevadores de vidro e um espetacular domo de vidro iluminado, em estilo Tiffany. Saia até o convés e desfrute de quatro piscinas, sete hodromassagens, um escorregador em espiral e bares à sombra.

(REVISTA Carnival, 2003, p. 28)

Se a sedução textual tem a ver com a interpretação do turista por conta do apelo publicitário, não mensuramos em saber, mas que a compreensão de um texto de folder ou folheto traduz a verdadeira intenção do leitor-turista isso não há dúvida. Veja-se:

Se a interpretação de um texto deve traduzir o conjunto das intenções do autor, há que se levar em conta o fato de o texto comportar em geral uma argumentação implícita, que constitui o seu essencial.

(Perelman, 1996:141)

Por isso, a interpretação é fundamental para que haja sedução textual. Só assim o leitor poderá ser levado à concretização do seu desejo, do consumo de seu produto, desde que sejam atendidos todos os requisitos discursivos de lazer e prazer.

\subsection{Usos argumentativos nos folhetos e nos folders}

Em uma parte chamada CARNIVAL TRIUMPH (Revista Carnival, p. 30), tornase bastante interessante que, nesse nível de argumentação escrita, os folhetos e folders trabalhavam como os usos de influência penetravam na sedução textual dos 
turistas. Apesar disso, não há dúvida alguma de que a combinação de imagens também contribui para a definitiva concretização desse pacote.

Com base nessa generalização de características dos lugares, Chain Perelman comenta:

\begin{abstract}
Resulta dessas poucas observações que o uso das noções consoante o desejo de valorizar ou desvalorizar o que elas qualificam não deixa de influir profundamente em seu significado. Esta não é, como certas análises tenderiam a faze-lo crer, uma justaposição de dois elementos, um descritivo, o outro emotivo. O que foi chamado de "sentido emotivo" das noções é um componente que o teórico cioso de expor a complexidade dos efeitos da linguagem é obrigado a introduzir quando quer corrigir.
\end{abstract}

(Perelman, 1996:158)

Assim, o descritivo e o emotivo juntam-se para estabelecer parâmetros discursivos que levem às interpretações turísticas do próprio leitor-turista. Com isso, esse leitor convence-se de que a verdade contida naquelas imagens-textos representa muito mais do que palavras, mas, sim, de apelos de propaganda em detrimento da compra de pacotes turísticos.

A influência da teoria do discurso vem provar que a relação texto-fotografia, fotografia-texto exerce processos inimagináveis de sedução textual, sobretudo no que se refere às propagandas escritas em turismo.

Para ratificar tal afirmação, temos:

O que a escolha das premissas oferecia de particular ao nosso estudo é que seria ilícito é que seria lícito e útil reconhecê-la sob avatares muito diversos: a seleção dos dados que tem por corolário conceder-lhes a presença, o papel da interpretação, a escolha de certos aspectos dos dados realizada pelo uso do epíteto, pela inserção dos fenômenos numa ou noutra classe previamente conhecida dos ouvintes e, enfim, a escolha que se opera pelo uso e pela transformação das próprias noções.

(Perelman, 1996:159)

Como vimos, a questão dos dados em análise do discurso é muito séria, principalmente pelo fato de que o uso argumentativo relaciona-se diretamente com o "comprar" do objeto que, nesse patamar, já é a própria consumação do pacote 
turístico oferecido. Em outras palavras, a persuasão por meio do folheto funcionou relativamente bem.

CAPÍTULO IV: OS DADOS DOS FOLDERS E FOLHETOS EM FORMA DE DISCURSO

4.1. Formas verbais na argumentação de alguns folhetos e folders

É bastante natural assinalar que todos os folhetos e folders analisados possuem textos cujas formas verbais, os vocábulos e as próprias construções obedecem um ritual discursivo fundamental para a cativação e dominação da vontade do leitor-turista.

Em PARADISE Cruzeiros de 7 dias pelo Caribe, saindo de Miami (cf. Revista Carnival, 2003, pp. 32-33), percebemos a constância e manutenção de verbos que traduzem a idéia da sugestão e do entretenimento. Vejamos um exemplo: 


\section{O futuro encontra o passado}

Entre no átrio futurista do PARADISE, com seus seis andares e seu maravilhoso domo de vidro iluminado. Dê o seu passeio da tarde pelo Carnival Boulevard. O piso de tábuas corridas e o mármore luxuoso trazem reminiscências dos clássicos, transatlânticos de luxo do passado. Tente a sorte no vibrante Majestic Casino. Zarpe num cruzeiro em direção a sete magníficos dias pelo leste ou oeste do Caribe e percorra alguns dos locais mais badalados do Caribe. Visite Cozumel, Grand Cayman, Ocho Rios, Jamaica, Bahamas, Porto Rico e St. Thomas. Tendo um toque do futuro, e um toque do passado, o PARADISE oferece de tudo!

O poder da sedução dos verbos na análise do discurso é realmente muito interessante. Aliada à imagem, o texto ganha em beleza adjetival, projeção e unidade nas construções verbais. Por isso, em encontra o passado", "Entre no átrio, Dê o seu passeio, Tente a sorte, Zarpe num cruzeiro e "Visite Cozumel, tem-se uma unidade temporal dos verbos, incutindo uma idéia de presente e de futuro no leitor-turista. $O$ presente deve representar o exato momento em que ele leu e o futuro será tudo quanto o folheto promete em oferecer em lazer, entretenimento e diversão.

Os adjetivos, que aqui são responsáveis pelas qualificações impecáveis das características dos navios e dos ambientes, têm a função primordial de trabalhar o convencimento final do leitor-turista, sobretudo no que tange ao consumo do produto em um futuro próximo.

Por esse e outros motivos que o argumento do folheto e/ou folder ganha em potencialização de convencimento e posterior sedução, usando para tal duas coisas básicas: a palavra e a imagem.

Ainda em referência às formas verbais na argumentação, percebe-se que o tempo verbal mais usado é o presente do indicativo. Tal estratégia deve-se ao fato de que o leitor-turista precisa situar-se em um tempo mais próximo de sua efetiva 
leitura. Como o folheto trabalha a questão futura, a leitura no presente dar ao leitor a projeção discursiva que mais vai se adequar às suas necessidades de lazer e diversão. Vejamos um exemplo:

"O futuro encontra o passado" (cf. Revista Carnival, 2003, p. 32)

Podemos ver que a palavra sublinhada é o entremeio de dois vocábulos com significados opostos, mas com projeções muito otimistas. Enquanto "futuro" traduz ação benéfica a acontecer, "passado" mostra não a beleza dos fatos passados, mas, sim, as maravilhas do cruzeiro que propiciará as delícias de suas formas e curvas antigas.

A esses ícones de argumentação, podemos mencionar o que Perelman pensa a respeito:

[...] antes de qualquer argumentação, é geralmente importante apresentar um enunciado em termos suscetíveis de evocar outros por derivação, verdadeira ou imaginária.

(Perelman, 1996:171)

\subsection{As modalidades na expressão do pensamento}

Ao proceder à análise dos folhetos e folders selecionados, determinamos que cada um deles obedeceria as chamadas modalidades do discurso, as quais, sem dúvida, constituem-se como fundamentais para a interpretação discursiva do material analisado.

Assim, apesar de enunciar a questão dos articuladores da língua (as construções sindéticas e subordinadas, de âmbito Kantiniano), o vernáculo presente nos folhetos leva-nos a analogia entre modalidades e argumentação. Por isso, achamos necessário mencionar, segundo Perelman, cada uma dessas modalidades: 
As modalidades, no sentido técnico do lingüista, são, como geralmente se admite, em número de quatro: a assertiva, a injuntiva, a interrogativa e a optativa.

A modalidade assertiva convém a qualquer argumentação; não há por que falar dela.

A modalidade injuntiva se expressa, em nossa língua, pelo imperativo [...]

A modalidade optativa talvez seja a que melhor se preta à expressão das normas.

(Perelman, 1996:181)

A partir das definições de Perelman, podemos constatar que, na grande maioria dos folhetos, predominou as modalidades injuntivas, as quais sempre direcionaram o texto publicitário do turismo para as sugestões, os convencimentos e, por fim, a sedução.

Para tanto, vejamos alguns fragmentos dessas amostras nos folhetos:

1. Participe de uma exótica aventura

Viaje de Miami para os destinos mais exóticos, a bordo do incrível CARNIVAL SPIRIT. Criamos uma inovadora classe de navio - a classe "Spirit". Este navio, novo e exclusivo, foi projetado com 80\% das cabines oferecendo uma deslumbrante vista para o mar, sendo que dessas cabines outros $80 \%$ possuem terraço privativo. A bordo deste navio, você pode fazer cruzeiros a destinos mais remotos da parte sul e ocidental do Caribe do que nunca, visitando exóticos paraísos tropicais. Você vai passar oito dias gloriosos navegando para alguns dos lugares mais belos do planeta.

(REVISTA Carnival, 2003, p. 34) 
Como vimos acima e afirmamos anteriormente, tanto o verbo do título quanto o do início do texto está no modo imperativo, resultando, nesse caso, na modalidade injuntiva. Assim, os verbos "Participe" e "Viaje" exercem uma função primordial na análise do discurso, o que Perelman chama de "propriedade do discurso".

Até o tempo presente, segundo ele, tem uma influência no poder argumentativo do emissor sobre o receptor de qualquer mensagem. Por isso, Perelman afirma:

O presente tem também a propriedade de proporcionar mais facilmente o que chamamos de "sentimento de presença". Os retóricos reconheceram-lhe com freqüência essa função. Talvez seja esta a razão de seu emprego pelos romancistas contemporâneos.

(Perelman, 1996:181)

4.3. Formas de discurso nos folhetos e folders e os elementos de argumentação

Todas as formas verificadas nos folhetos e folders tinham um objeto em particular: produzir efeitos argumentativos sobre os leitores. Essa comunhão com o receptor da mensagem tem, também, uma função importante no folder turístico.

Dessa forma, a própria forma, as cores, as palavras e o texto de turismo não podem desenvolver-se sem, antes, estabeleceram relações de afinidade com o leitor, mesmo que elas não possam convencer definitivamente o turista.

Por conta dessa sedução textual tanto mencionada ao longo desse trabalho, temos, em relação à forma e aos elementos da argumentação, os clichês, os provérbios e, o que é mais importante, talvez, para o turismo, os slogans. 
Não obstante, basta observamos os folhetos selecionados que chegaremos a várias conclusões que ratificam cada um desses elementos enunciados. Com o objetivo de ilustrar a presença de tais elementos, vejamos:

1. Um jeito de fazer um cruzeiro

Queiram todos subir a bordo de nossa mais recente obra-prima, o CARNIVAL LEGEND. O navio foi projetado para dar destaque a todas as características que você tanto deseja: panoramas mais inspiradores, destinos mais exóticos e mais opções para suas refeições. Dedicamos especial atenção às cabines, a maioria das quais oferece vista para o mar e maioria dessas com terraço privativo. O CARNIVAL LEGEND é perfeito para quem busca um refúgio íntimo.

(REVISTA Carnival, 2003, p. 36)

Vemos, assim, que tanto os clichês usados (cf. "obra-prima") como os "slogans" (Cf. Um jeito novo de fazer um cruzeiro) desenvolvem no leitor ansiedades e desejos impetuosos, quase impossíveis de serem resistidos. Talvez os slogans, na área da sedução turística, sejam fundamentais para influenciar na decisão de um turista por um determinado pacote em detrimento de outro.

Em relação aos valores da argumentação, sobretudo nos folhetos e folders pesquisados, podemos afirmar que o mais importante para o marketing do turismo é o juízo de valor. Com a ajuda dos slogans bem estruturados, os juízos de valor estabelecem uma larga vinculação com todas as propagandas de turismo, em especial no nível escrito. Sobre esse respeito, temos a seguinte afirmação:

Juízos de valor e, mesmo, sentimentos puramente subjetivos podem, mediante
artifícios de apresentação, ser transformados em juízo de fato. A frase "estas maçãs
não me apetecem" para "não gosto destas maçãs" permite operar uma espécie de
transferência de responsabilidade. Reprova-se ao objeto não emitir apelo, considera-
se que, se houve reação desfavorável, isso resulta de um comportamento do objeto
[...].

(Perelman, 1996:204)

Como podemos constatar, os juízos de valor têm uma grande importância nas decisões e/ou julgamentos de valor da propaganda turística, principalmente se 
mencionarmos as estratégias de marketing que sempre são desenvolvidas com duas intenções básicas: seduzir e convencer. Uma prova disso é o título do próximo slogan turístico Um pouco de tudo (Revista Carnival, 2003, p. 36).

Conforme as palavras de Perelman, a generalização da expressão acima apenas vem reforçar a natureza e a força do discurso aliado à argumentação, o que resulta em grau de convencimento quase irresistível.

\section{CAPÍTULO V: AS TÉCNICAS ARGUMENTATIVAS USADAS NOS FOLHETOS E FOLDERS ANALISADOS}

\subsection{Características da argumentação quase lógica}

Começaremos esse capítulo por enunciar as características da construção do argumento em analogia com os argumentos quase lógicos. Em primeiro lugar, veremos o que Perelman diz sobre o assunto:

Em todo argumento quase lógico convém pôr em evidência, primeiro, o esquema formal que serve de molde à construção do argumento, depois, as operações de redução que permitem inserir os dados nesse esquema e visam torna-los comparáveis, semelhantes, homogêneos.

(Perelman, 1996:218)

É claro que a relação entre argumento e lógica estão intrinsecamente ligados e, por isso, eles não podem ficar de fora de qualquer propaganda turística, em especial se for em nível escrito da linguagem. Assim, o caráter não-formal será uma máxima da linguagem discursiva na argumentação, sendo, portanto, fundamental para a construção de qualquer sedução no leitor-turista.

De certa forma, é isso que se constata em: 


\section{O máximo em matéria de cruzeiro}

O máximo em matéria de cruzeiros de férias é sem dúvida uma empolgante visita ao Canal do Panamá a bordo do CARNIVAL SPIRIT. Com 80\% das cabines externas você ocupará o "melhor lugar do navio". Aprecie as incomparáveis belezas naturais à medida que esse navio ancora em lugares exóticos como Porto Vallarta e Acapulco, no México. Depois, ao cruzar de um oceano para o outro, deslumbre-se com o Canal de Panamá, uma obra-prima da engenharia.

(REVISTA Carnival, 2003, p. 38)

A característica que se observa no trecho citado é a popularização do substantivo "máximo" no título da propaganda. Tal estratégia intensifica a citação de Perelman no sentido de que o esforço mental da interpretação leva a uma redução do informal ao formal no folheto. Essa linguagem favorece, então, a condição de seduzido por parte do turista que, na verdade, deseja realizar os seus sonhos realizados com a viagem no navio.

\subsection{Contradição e incompatibilidade}

Ambas as técnicas apresentam diferentes aplicabilidades no turismo. A contradição torna-se necessária à medida que determinadas situações são criadas justamente para projetar o imaginário do turista no pacote em que ele estiver interessado. A incompatibilidade, entretanto, surge como algo não muito aconselhável e desejável em um folheto turístico.

Por isso, segundo a análise Perelmaniana do discurso, os folhetos de turismo devem apresentar mais contradição e menos incompatibilidade. Sendo assim, um título como "A cidade à beira da baía" (cf. p. 39, revista Carnival) ou "Liberte-se!" (cf. Revista Carnival, p. 40) alimentam o imaginário do turista no que diz respeito às suas projeções em um pacote marítimo, por exemplo.

Para reforçar o que foi dito, vejamos o seguinte trecho:

Algumas incompatibilidades podem resultar da aplicação de determinadas situações de várias regras morais ou jurídicas, de textos legais ou sacros. Enquanto a 
contradição entre duas proposições pressupõe um formalismo, ou pelo menos um sistema de noções unívocas, a incompatibilidade é sempre relativa a circunstâncias contingentes, sejam estas constituídas por leis naturais, fatos particulares ou decisões humanas $[\ldots]$.

(Perelman, 1996:223)

5.3. Técnicas que visam apresentar teses como compatíveis ou incompatíveis

Em turismo, obviamente que desejamos teses compatíveis com os anseios dos clientes de serviços turísticos. É por isso que, em análise do discurso, todos os folhetos analisados tiveram a tendência para compatibilidade ao inconsciente do turista.

Na série INSPIRATION (Revista Carnival, 2003, p. 42), a incompatibilidade vocabular influenciava a compatibilidade do imaginário. Em "A inspiração de férias no mar" (Revista Carnival, p. 42), vemos que a palavra "mar" gera uma projeção de agradabilidade em oposição a MAR como algo perigoso e inexplorado.

Logo a tese a ser explorada é a oposição do que o mar significa na prática. Sendo dessa forma, o turista, ao ler o folheto, projetar-se-á nas belezas que o mar oferece em detrimento do discurso de que ele é perigoso e profundo, por exemplo. Sobre isso, diz o discurso Perelmaniano:

Umas das técnicas para expor incompatibilidades consiste em afirmar que, duas teses que se excluem, ao menos uma é sempre aplicável, o que tornaria inevitável o conflito com a outra tese, contanto que sejam aplicáveis, ambas, a um mesmo objeto. As duas teses se tornarão compatíveis se uma divisão no tempo ou uma divisão quanto ao objeto permitirem evitar o conflito [...].

(Perelman, 1996:229) 
Essas técnicas também podem ser vistas em um dos trechos da INSPIRATION:

Diversão e muito o que fazer

Viaje pelo mundo sem sair do luxo de nosso navio. A bordo e a caminho de próximo porto você poderá desfrutar das várias atrações que o navio oferece: clubes, bares, biblioteca e seus mirantes com vistas panorâmicas ou tomar um coquetel no charmoso Café des Artistes. [...]

(REVISTA Carnival, 2003, p. 42)

5.4. Os argumentos de comparação e de reciprocidade

Ambos os argumentos têm uma importância singular para análise do discurso. Esses dois tipos de argumentação partem de pressupostos muito próximos do processo de convencimento e/ou sedução por meio de folhetos e folders turísticos.

Por isso, a argumentação de comparação é, segundo Perelman, aquela que

Não poderia ir muito longe sem recorrer a comparações, na qual se cotejam vários objetos para avalia-los em relação ao outro. Nesse sentido, os argumentos de comparação deverão ser distinguidos tanto dos argumentos de identificação quanto do raciocínio por analogia.

(Perelman, 1996:274)

Já os argumentos de reciprocidade exercem o papel de ampliar o tratamento a situações correspondentes. Dessa forma, não podemos deixar de admitir que as analogias contribuem substancialmente para estabelecer uma relação íntima entre os argumentos e os folhetos citados.

O turismo, por sua vez, trabalha claramente com as duas argumentações, objetivando, nessa perspectiva discursiva, engendrar características que tornem o folheto agradável e sedutor. Como exemplo, temos: 


\section{Divertimento total}

Existe definitivamente um lugar onde a diversão não é apenas um conceito vago, mas uma realidade diária: ORLANDO, na região central da Flórida! Aqui a vida gira em torno dos parques temáticos, uma infinidade de compras e uma alegre vida noturna. [...]

(REVISTA Carnival, 2003, p. 44)

E, ainda, temos mais um exemplo:

Além do infinito

Cinco, quatro, três, dois, um e, parta para viver a sua maior aventura no espaço sideral! [...]

Notem que em ambos os exemplos, a comparação e a reciprocidade fazem do folheto turístico uma eterna analogia com coisas e objetos, sobretudo ajudados com as mirabolantes fotos e paisagens do estilo DIVERSÃO AO ESTILO FLÓRIDA.

\section{CAPÍTULO VI: OS ARGUMENTOS BASEADOS NA ESTRUTURA DO REAL DOS FOLHETOS E FOLDERS}

6.1. O vínculo causal e a argumentação

A constatação de folhetos que seguiam um vínculo causal muito forte foi uma das premissas da análise do discurso. Com isso, possibilitou-nos investigar como a argumentação estabelece ligação direta com o que é anunciado nas revistas. Vejamos um exemplo da Revista Carnival:

\section{Momento de sossego}

Após visitar as grandes atrações de Orlando, um jogo de golfe é exatamente aquilo de que você precisa para relaxar e curtir. A região central da Flórida abriga uma série de luxuosos resorts com campos de golfe, cada um 
especialmente projetado para oferecer tudo que os golfistas de todos os níveis podem desejar. Quer prefira o velho charme da Flórida, quer ande em busca de uma atmosfera moderna, você vai encontrar o que deseja.

(REVISTA Carnival, 2003, p. 45)

Ao longo do texto do folheto "Momento de sossego", podemos observar que o jogo de golfe tem como seqüência os verbos "relaxar e curtir", o que dão uma impressão de que o luxo e lazer são argumentos de vínculo causal. Para Perelman, existem três tipos de argumentação:

a) as que tendem a relacionar dois acontecimentos sucessivos dados entre eles, por meio de um vínculo causal;

b) as que, sendo dado um acontecimento, tendem a descobrir a existência de uma causa que pôde determiná-lo;

c) as que, sendo dado um acontecimento, tendem a evidenciar o efeito que dele deve resultar;

Todas essas argumentações levam-nos a inferir que os folhetos, em geral, tendem a trabalhar diretamente com os princípios lógicos da língua, ou seja, as belezas em cores e textos bem escritos são ferramentas de sedução evidente, na qual os já tão discutidos seguem todo um ritual de colaboração e comemoração.

\subsection{O argumento pragmático}

Na seção FANTASY, da revista Carnival, página 46, constatou-se que os argumentos pragmáticos funcionam de forma bem mais eficiente e duradoura. Por isso, no título "O lugar ideal para você se divertir" (cf. p. 46), percebe-se uma certa conseqüência favorável para as pretensões do leitor-turista. 
Para Perelman, o argumento pragmático:

É aquele que permite apreciar um ato ou um acontecimento consoante suas conseqüências favoráveis ou desfavoráveis. Esse argumento desempenha um papel a tal ponto essencial na argumentação que certos autores quiseram ver nele o esquema único da lógica dos juízos de valor [...].

(Perelman, 1996:303)

Em relação à revista, temos o seguinte exemplo:

O lugar ideal para você se divertir

Nas Bahamas você vai encontrar "o seu tipo de diversão", praias de areias brancas, flores de todas as cores, lojas duty free repletas com os melhores artigos para presentes e perfumes que todos adoram. Sem falar na simpatia do povo caribenho, No FANTASY, você tem a ensolarada paisagem das Bahamas e a magia do centro da Flórida: a combinação perfeita para férias inesquecíveis!

(REVISTA Carnival, 2003, p. 46-47)

Pode-se notar que no folheto acima é possível localizarmos a referência de lugar, associada com as possíveis conseqüências positivas de embarcar para Bahamas, por exemplo. A simpatia do povo caribenho é outro atrativo que seduz o leitor-turista, ainda mais se imaginarmos que essa projeção é extremamente favorável.

\section{CAPÍTULO VII: AS LIGAÇÕES QUE FUNDAMENTAM A ESTRUTURA DO REAL}

7.1. A argumentação pelo exemplo

Durante o trabalho, pude verificar os muitos folhetos $\mathrm{e}$ folders que expressavam a argumentação pelo exemplo. As formas fotográficas e as gravuras, 
de modo geral, mostram coisas mirabolantes, comidas, culturas e rituais regionais em detrimento do hasteamento da bandeira nacional.

Os exemplos encontrados em FANTASY demonstram claramente que os exemplos ajudam a crescer rapidamente no leitor-turista o desejo e a vontade de embarcar na viagem do navio. Vejamos três exemplos:

\section{Um resort mágico}

Se você está em busca de piscinas reluzentes, conveses imensamente espaçosos ou uma variedade infinita de salões de estar e da ação vibrante de um cassino, o FANTASY é ideal para satisfazer todos os seus desejos. Os seus filhos se divertirão com os programa e atividades "Camp Carnival", inteiramente supervisionados. Todas as noites a bordo há uma variedade de atrações no Universe Lounge, dança no Cats Club, drinques e bate papos no Cleopatra's Bar.

(REVISTA Carnival, 2003, p. 46)

2. A ilha da Grand Bahama deixará você fascinado com suas águas cristalinas, seus campos de golfe e uma vastidão de praias de areias brancas.

(REVISTA Carnival, 2003, p. 47)

3. A cultura da Bahamas é a única, abrangendo os mais diversos costumes nativos. Os habitantes da ilha com suas tradições e crenças modelaram a cultura local formando o estilo de vida contemporâneo.

(REVISTA Carnival, 2003, p. idem)

\subsection{Relações entre os termos de uma analogia}

Para estabelecermos uma associação com os folhetos de turismo, será necessário, de início, mostrarmos o que pensa Perelman: 
Dizendo que em toda analogia há uma relação entre quatro termos, apresentamos, claro, uma visão esquemática das coisas. Cada um deles pode, de fato, corresponder a uma situação complexa, sendo isso mesmo que caracteriza uma analogia rica [...].

(Perelman, 1996:427)

De acordo com o conceito de analogia apresentado, é óbvio que os próprios elementos do discurso nos folhetos constituem-se como grandes analogias ricas, essencialmente se pensarmos que a combinação de cores e lugares transforma o texto em uma analogia tão rica que chega a seduzir imediatamente.

Na própria abertura da página 48 (cf. CARNIVAL PRIDE), da revista Carnival, pode-se tanto ver como deslumbrar as belas imagens que compõem o cenário convidativo para o turista: os navios, as casas, as paisagens e os salões internos.

Todas constituem-se como verdadeiras analogias que, na verdade, não conseguem fazer outra coisa senão convencer o leitor-turista a consumir o pacote que ali era-lhe ofertado.

\subsection{Efeitos da analogia}

Como já vimos anteriormente, a propaganda vs. publicidade do turismo é um tipo de atividade que necessita de elementos textuais e visuais que, de certa forma, influenciam comportamentos e atitudes. É por isso que essa análise perpassa pelo discurso escrito, haja vista os mais elucidados tipos de folhetos e folders aqui apresentados.

Ainda sim, falamos sobre a analogia como ponto de partida. Sob essa ótica, podemos admitir que a analogia permite-nos concluir que é uma comparação fundamental no discurso Perelmaniano. Percebamos o que nos diz Perelman: 
A analogia permite compreender melhor as relações entre a graça e o livre-arbítrio e a respectiva importância do homem e de Deus no pecado e na salvação.

(Perelman, 1996:435)

Para ilustrar tal citação, vejamos alguns fragmentos analisados:

1. Visite lugares empolgantes!

Com seus salões com temas internacionais, o incrível CARNIVAL PRIDE é o navio perfeito para você. Escolha entre os itinerários de 7 dias. Um jeito fantástico de apreciar Belize City — em Belize, Progresso/Mérida, no México e descobrir os tesouros intocados da natureza. Aos que amam o sol, o cruzeiro em direção leste oferece delícias e alegria de férias na ilha particular de Hall Monn Cay, na colorida St. Thomas e na cálida St. Maarten.

(REVISTA Carnival, 2003, p. 48)

2. Noites pontilhadas de estrelas

Deixe-se contagiar pelo ambiente internacional enquanto vai passando de um magnífico salão para outro. Tome um drinque no Japanese Ivory Bar ou leia um livro interessante no ambiente sueco da Nobel Library. Comece a viver as emoções que a noite Ihe reserva na sala de espetáculos Taj Mahal. Após o show, dance noite adentro no Starry Night Dance Club.

(REVISTA Carnival, 2003, p. 48)

Note-se que de certa forma várias são as analogias construídas ao longo do discurso. No folheto 1, temos palavras que já traduzem com perfeição a vinculação do prazer de viajar no Carnival com os prazeres da vida. Para tanto, vemos os usos de vocábulos como "perfeito para você" e "os tesouros intocados da natureza".

No folheto 2, a generalização de palavras análogas - como "ambiente internacional", "magnífico salão" - mostram uma atmosfera bastante agradável e empolgante para os turistas. A presença da palavra "emoções" traz-nos a um nível de absoluta vinculação com um dia-a-dia prazeroso nos navios da Carnival. 


\subsection{As expressões com sentido metafórico}

No que diz respeito às relações metafóricas, temos a dizer que em todos os folhetos analisados foi preponderante a presença de estruturas metafóricas, cujos objetivos tinham como ponto principal despertar o leitor-turista para uma realidade análoga às belezas da vida, propiciando-lhe lazer e divertimento.

Para ratificar tais observações, temos alguns fragmentos:

"Prazeres tropicais" e "os melhores perfumes vêm nos menores frascos".

(REVISTA Carnival, 2003, p. 50)

Vê-se que a analogia não é descartada quando se analisa a aplicação da metáfora como forma de incitar o desejo do leitor. Nesse ponto, pode-se considerar a metáfora como "adormecida", ou seja, aquela que possui o valor semântico primitivo ou já denotado. Perelman nos esclarece um pouco mais: A metáfora adormecida, ou expressão com sentido metafórico, pareceu a Whately, na
esteira de Stewart e de Copleston, um instrumento muito superior à metáfora atuante,
por ter perdido o contado com a idéia primitiva por ela denotada; da mesma forma,
Stevenson admite que, por sua interpretação ser unívoca, ela pode fornecer uma
razão, ao contrário da metáfora atuante, que seria apenas sugestiva.

(Perelman, 1996:459)

Sobre o fenômeno da analogia para gerar a metáfora, vejamos o que nos diz novamente Perelman:

A maneira mais usual de despertar uma metáfora é desenvolver de novo, a partir dela, uma analogia. Assim é que, para despertar a metáfora adormecida na expressão "levado por suas paixões [...].

(Perelman, 1996:460)

Dessa forma, podemos inferir, por último, que metáfora é um elemento de pura fusão entre os termos, facilitando a sedução contínua pela palavra do leitorturista. Assim, diz, ainda, Perelman:

A metáfora, fusão analógica, desempenha todos os papéis representados pela analogia. Desempenha-os melhor ainda em certos pontos, porque reforça a analogia; a metáfora condensada se integra na linguagem. Mas apenas o despertar da metáfora possibilitará distinguir-Ihe a estrutura e, vencida essa etapa, superar a analogia [...].

(Perelman, 1996:465) 


\title{
CAPÍTULO VIII: AS DISSOCIAÇÕES DAS NOÇÕES
}

8.1. Ruptura de ligação e dissociação

Em análise do discurso, ruptura de ligação e dissociação devem estabelecer uma relação quase que concomitante. Para Perelman, ambas são importantes para a consecução dos elementos discursivos, sobretudo quando se referem aos folhetos e folders de turismo.

Segundo Perelman:

\begin{abstract}
À primeira vista, a diferença entre ruptura de ligação e dissociação das noções é profunda e imediatamente discernível, mas, na realidade, também essa distinção, como as outras posições ditas de natureza, pode ser muito controvertida. Conforme as ligações entre elementos forem consideradas "naturais" ou "artificiais", "essenciais" ou "acidentais", um verá uma dissociação das noções naquilo que, para outro, não passa de uma ruptura de ligação [...].
\end{abstract}

(Perelman, 1996:427)

De acordo com as idéias expostas por Perelman, essa ruptura parece mais uma distinção filosófica do que pragmática. Nos folhetos, na prática, isso funciona muito bem, ainda mais porque qualquer propaganda turística implica em conceber a estrutura das relações mercadológicas, ou seja, quanto mais colorido e bem escrito o texto, mais sedutor ele se tornará para o leitor-turista. 


\subsection{A expressão das dissociações}

A questão da dissociação é um dos elementos do discurso que merece alguns comentários. Em primeiro lugar, tal característica acontece principalmente pela presença de termos opostos na língua. No turismo, o que se vê é uma perpetuação de textos escritos que sempre estão trabalhando com oposições "melhores do que a outras".

Isso faz-nos imaginar que as fotografias presentes nos folhetos analisados contribuem para os chamados pares de oposição, que ora mostram uma realidade maravilhosa, ora esplendorosa e, por último, ora espetacular.

Para Perelman, essa expressão caracteriza-se:

A presença dos pares filosóficos se revela, a quem conhece os usos de uma língua, por expressões características que possibilitam, ao primeiro olhar, distinguir o termo I do termo II. Assim é que, a partir da oposição "aparência vs. realidade" qualquer noção que seja pode ser dissociada pela adição dos adjetivos "aparente" ou "real", ou dos advérbios "aparentemente" ou "realmente". De um modo geral, todas as vezes que uma dissociação é assinalada por um par de substantivos, os adjetivos e os advérbios derivados poderão indicar novas dissociações.

(Perelman, 1996:495-6)

Assim, as dissociações são importantes para estabelecer vinculações fundamentais entre o texto e o leitor-turista. A concretização desse fim que parece filosófico, mas não é, configura-se exatamente no fato de que o texto é preparado para seduzir o leitor-turista em detrimento de um pacote $x$ ou y. O que fará com que ele decida é o nível argumentativo e persuasivo do texto lido. 
8.3. Enunciados que incentivam dissociação

Entre os muitos enunciados que podem provocar incentivar a dissociação, temos um muito importante para essa sustentação: o paradoxo. Esse tipo de enunciado estabelece uma ligação direta com a propaganda de folhetos em turismo. Por isso expressões como "viajar é viajar", "turismo é turismo", "um tostão não é um tostão" têm significações diversas em relação ao propósito explícito no discurso.

Com vistas à essa exemplificação, temos:

As expressões paradoxais sempre convidam a um esforço de dissociação. Toda vez em que é anexado a um substantivo um adjetivo, ou um verbo, que parece incompatível com ele (douta ignorância, mal ditoso, alegria amarga, pensar o impensável, exprimir o inexprimível, as condições da capitulação incondicional, apenas uma dissociação permitirá a compreensão.

(Perelman, 1996:503)

É por isso que nos vemos em uma situação em que o texto - pelo menos no turismo - tem o objetivo primeiro de convencer o leitor a decidir-se rapidamente por aquilo que as revistas em geral estão oferecendo. Dessa forma, em títulos do tipo:

"A melhor cozinha e o melhor entretenimento sobre os mares"

"Muito o que fazer, muito o que ver"

(REVISTA Carnival, 2003, pp. 53-54)

Percebe-se que a ligação entre as frases é estreitamente "comercial" no sentido de que o objetivo é seduzir o leitor a escolha do ofertado. Mas tudo isso não passa de uma mera articulação discursiva - aqui já estudada - que possibilita mensurarmos o quão os níveis da argumentação estão sempre presentes em folhetos e folders comerciais de turismo. 


\subsection{As definições dissociadoras}

Definir, em turismo, é sempre interessante em relação aos processos de descrição e análise que, em alguns folhetos, foram identificados. Dessa forma, não foi diferente nos folhetos selecionados, os quais mostraram relativas definições benéficas no que se referiam às externalidades naturais e urbanas.

Como exemplo, vejamos os seguintes trechos:

\section{Um lugar inigualável}

Não existe lugar como a cidade de Nova York. Broadway, Times Square, Little Italy, Chinatown, Greenwich Village, Fifth Avenue, Central Park - uma interminável lista de lugares famosos, tais como os prédios da Nações Unidas, Rockefeller Center, Empire State, Radio City, e o Metropolitan Museum. Tudo isso e muito mais pode ser encontrado na cidade que é verdadeiramente única no mundo."

2. Navegue pelas águas encantadas da costa leste

Este exclusivo cruzeiro de 8 dias parte do coração de Nova York, navegando pelas águas do Atlântico para leva-lo ao Caribe. Você vai ficar sem fôlego ao desfrutar vistas de românticos fins de tarde em paraísos tropicais a partir de nosso magnífico resort flutuante. Prepare-se! Praias em tons de ouro, florestas tropicais, centros culturais, arquiteturas e história esperam por você em cada porto.

(REVISTA Carnival, 2003, pp. 54-55) 
A partir desses fragmentos, podemos contra-argumentar que para todo argumento plausível existe uma definição relevante. Destarte, seria interessante enveredarmos pelos caminhos da lógica discursiva, uma vez que partimos da premissa de que todo discurso não se articula se não houver definições relevantes.

No trecho 1, só o adjetivo do título "inigualável” já mostrará que, a partir dali, o substantivo "lugar" será desmembrado em vários: "Broadway, Times Square, Little Italy, Chinatown, Greenwich Village, Fifth Avenue [...]"

Assim, a definição geográfica de cada cidade é importante para analisarmos e situação turística do lugar pretendido do leitor-turista.

No trecho 2, o que vemos é um discurso repleto de enunciações geográficas, as quais são muito importantes para a delimitação do trajeto de centros culturais de lazer e divertimento.

Por isso, para Perelman, a definição é:

Um instrumento da argumentação quase-lógica. É também um instrumento da dissociação nocional, notadamente todas as vezes que ele pretende fornecer o sentido verdadeiro, o sentido real da noção, oposto ao seu uso habitual ou aparente.

(Perelman, 1996:504) 


\section{CAPÍTULO IX: A INTERAÇÃO DOS ARGUMENTOS}

9.1. Interação e força dos argumentos

Qualquer tipo de comparação, analogia ou mesmo paradoxo — até aqui bem estudadas - pressupõe o que chamaremos de poder dos argumentos associado à interação dos mesmos. Por conseguinte, todos os folhetos das revistas analisadas têm essa interação que é munida pela interação entre o produto vendido pelas revistas de turismo.

Vejamos alguns trechos que elucidam tal fato:

1. Não há lugar como a Nova Inglaterra

Da "Big Apple", ou seja, de Nova York às praias rochosas do Maine e aos vilarejos de pesca do Canadá, O CARNIVAL VICTORY leva você! Escolha entre os itinerários de 4, 5 ou 7 dias e aprecie a linda paisagem do Atlântico Norte. Férias perfeitas para quem deseja o melhor dos dois mundos, o agito da Big Apple e a tranqüilidade das cidades portuárias do Atlântico Norte. No nosso cruzeiro à Nova Inglaterra você irá curtir tudo e muito mais!

(REVISTA Carnival, 2003, pp. 56-57)

\section{Inicia-se uma nova estação}

Não há espetáculo mais magnífico da Natureza do que a transformação de cores quando começa o outono na Nova Inglaterra. Partindo de Nova York, você navegará até a histórica Boston, com suas inúmeras atrações à beira do mar, e pitorescas cidades coloniais. Em seguida, você partirá para a bela Portland, no Maine, antes de prosseguir para um dos tesouros mais maravilhosos da América do Norte, Nova Escócia, Canadá. Em seguida, o navio partirá em direção a Halifax e Sydney, dando tempo para você curtir o seu resort flutuante.

(REVISTA Carnival, 2003, pp. 54-55) 
Como o próprio Perelman diz:

Para guiar-se em seu empenho argumentativo, o orador utiliza uma noção confusa, mas ao que parece indispensável: a força dos argumentos.

(Perelman, 1996:524)

E, AINDA, ELE AFIRMA:

A força dos argumentos variará, pois, conforme os auditórios e conforme o objetivo da argumentação.

(Perelman, 1996:504)

Tudo isso ratifica-se em:

"O Maine é o local perfeito para apreciar a beleza do litoral da Nova Inglaterra.

Comece o dia no convés, apreciando as deslumbrantes paisagens e sentindo a brisa da manhã na chegada a Portland."

(REVISTA Carnival, 2003, pp. 56-7)

9.2. A apreciação da força dos argumentos, fator de argumentação

Acreditamos que tal fator aplica-se diretamente à questão do receptor das mensagens. Com isso, torna-se evidente que a ornamentação textual - nesse caso particular dos folhetos que são coloridos e fotográficos intencionalmente definitivamente faz com que o leitor-turista emita uma opinião favorável ao apelo da propaganda.

Vejamos isso nos seguintes fragmentos:

1, NOVA ORLEANS: A famosa The Big Easy

(REVISTA Carnival, 2003, pp. 58)

3. Uma cidade com personalidade

4.

Cheia de diversões. Descontraída, excêntrica e muito quente. A mescla de tantas personalidades e culturas torna Nova Orleans uma das cidades mais 
fascinantes da América! Principalmente quando se tem tempo para explorar suas atrações menos conhecidas, que podem ser encontradas quando se foge dos locais mais badalados.

(REVISTA Carnival, 2003, pp. 58)

5. Você será sempre bem-vindo

Carinhosamente chamada "The Big Easy" (A Bonachona), Nova Orleans recebe os visitantes de braços abertos. É muito fácil apaixonar-se por sua inigualável culinária, seu espírito alegre, sua música dolente e seu eterno chame sulino. Nova Orleans mantém a atmosfera de uma cidade pequena, oferecendo ao mesmo tempo todas as conveniências de uma grande cidade.

(REVISTA Carnival, 2003, pp. 58-59)

Como se constatou nos trechos acima, a força dos argumentos é necessária para o convencimento ou não do leitor-turista. Aqui o importante torna-se "argumento próprio" - o do leitor - e, o que é mais primordial, apesar dos argumentos serem genéricos, o poder de persuasão continua inalterado.

Por isso, Chain Perelman afirma:

A característica do argumento próprio para a causa é que, ao contrário dos argumentos mais genéricos, que poderiam ter sido encontrados espontaneamente por qualquer um, sem auxílio do orador, ele em geral acrescenta algo à nossa informação ou aos nossos hábitos de pensamento.

(Perelman, 1996:532)

\subsection{Ordem e persuasão}

No que se refere à análise do discurso, os aspectos de ordem e persuasão têm fatores preponderantes na análise de Perelman. Dessa forma, a ordem, por 
exemplo, será tratada sob a ótica das noções de exposição à medida que eles são enfocados.

Em relação à ordem em que aparecem as figuras e textos na revista pesquisada, observamos que, obviamente, as fotos influenciam em demasia a persuasão do leitor. Já o texto escrito, mesmo que ele esteja bem articulado, não consegue provocar o mesmo desejo do texto visual.

A respeito dessa dualidade ordem e persuasão, Perelman nos afirma:

Apenas se levarmos em conta a adesão das mentes, se passarmos de um ponto de vista formal para um ponto de vista psicológico, argumentativo, é que a ordem na demonstração, adquirirá importância: quando, em vez de considerar os axiomas como arbitrários, preocupamo-nos com seu caráter evidente e aceitável.

(Perelman, 1996:556)

Essa dualidade, como nos elucida Perelman, refere-se muito mais aos níveis argumentativos do que os níveis sintáticos e semânticos. A função primeira de um folheto ou folder de turismo é seduzir para, depois, convencer, resultando na persuasão em seguida. Para tanto veja o que nos o seguinte fragmento:

O que o nome sugere

Venha a bordo para entender a origem do nome deste navio. De dia, dê-se ao luxo de desfrutar a academia Náutica Spa e, depois, almoçar no Brasserie Bar and Grill. À noite, deslumbre-se com o espetacular teatro de revista apresentado no Paris Lounge. Faça rolar os dados no Monte Carlo Cassino. Dance no Rock and Roll Disco. Descontraia-se no Chopin Lounge. Deixe este navio inspirar você a desafiar todos os limites do divertimento.

(REVISTA Carnival, 2003, pp. 60-61) 
Percebamos, a seguir, o nível de persuasão do trecho abaixo:

Divertimento em terra ou no mar

Tenha o prazer de ouvir o legítimo jazz "Dixieland" de Nova Orleans. Delicie seu paladar com o néctar de frutas tropicais. Venha a bordo e desfrute dias ensolarados e noites plenas de música. Tudo isto é apenas o começo do seu cruzeiro no INSPIRATION. No mar ou em terra, prepare-se para viver uma semana da qual jamais esquecerá.

(REVISTA Carnival, 2003, p. 60)

9.4. Ordem do discurso e condicionamento

No capítulo anterior, Ordem e Persuasão ${ }^{9}$, discutimos como a ordem influencia os níveis de persuasão do leitor-turista. Por conta disso, também inserimos a idéia de que essa ordem do discurso acaba por intervir no condicionamento do mesmo. Ou seja, os elementos mínimos do discurso - os sintagmas nominais e verbais articulam-se de forma a oferecer pistas ao leitor de que, cedo ou tarde, ele será conquistado.

Sob esse prisma, o leitor-turista é visto como uma espécie de auditório no qual o orador - que aqui é o folheto ou folder - utiliza as técnicas mais sofisticadas de argumentação para convencer o leitor pela decisão de fazer ou não o cruzeiro, a viagem etc.

Com a intenção de ilustrar o que estamos falando, citaremos:

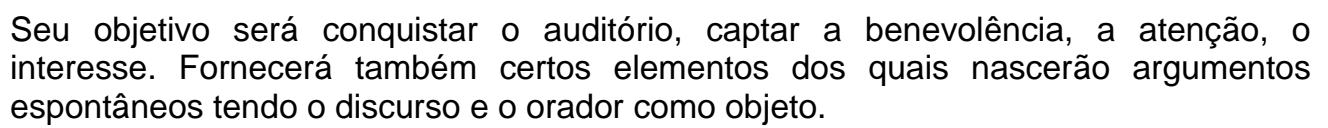
espontâneos tendo o discurso e o orador como objeto.

(Perelman, 1996:561)

Em relação aos fragmentos, temos os seguintes exemplos de discurso e condicionamento do leitor:

\footnotetext{
${ }^{9}$ É a capacidade de persuadir, induzir e convencer. CELSO, Pedro Luft, (1999), pág. 516.
} 
1. Mais diversão em seu cruzeiro

Dê-se o prazer de navegar em uma nova classe de navios da Carnival, o CARNIVAL CONQUEST: novo, maior e desenhado para que você possa aproveitar suas férias ao máximo. A vista oceânica pode ser apreciada de $60 \%$ das cabines desse lindo navio, as quais possuem também sala de estar. Reserve sua mesa para um jantar romântico no The Point, um clube gastronômico exclusivo; depois, prepare-se para shows de "Dixie Land Jazz", original de Nova Orleans. Saboreie frutas tropicais. Venha aproveitar dias cheios de sol e noites ao som da melhor música. Na terra ou no mar, prepare-se para uma semana inesquecível.

(REVISTA Carnival, 2003, p. 62)

2. Diversão sem limites

Assista às produções ao estilo Lãs Vegas no Astoria Lounge. Curta música no Red Hot Piano Bar. Dance toda a noite no Galax-Z Dance Club. Divirta-se com as apresentações cômicas no Islands in the Sky Lounge. Tente a sorte no Rainbow Club Casino. No CELEBRATION, o festival de alegria não tem limites.

(REVISTA Carnival, 2003, p. 65)

3. Key West é uma cidade extremamente original e lar do famoso escritor Ernest Hemingway. Faça um passeio tranqüilo pela casa onde ele morou e por seus jardins, que ficaram registrados como marcos históricos nacionais.

(REVISTA Carnival, 2003, p. 67)

\section{Um cenário sempre perfeito}

A vida é boa nas cidades balneárias do México - principalmente quando se está passeando na exuberante Riviera Mexicana. Passeie pelas ruas calçadas 
com pedras, ladeadas por vendedores simpáticos e amistosos. Barganhe na compra de flores recém-colhidas, cobertores nativos, artigos de prata e artesanato de madeira pintado em cores vivas. Faça uma incursão ao passado nas antigas e místicas ruínas do Império Maia quando visitar as ruínas de Chichen Itzá. Não esqueça de levar a máquina fotográfica: você não pode perder essa chance de captar o mais perfeito pôr-do-sol mexicano.

(REVISTA Carnival, 2003, p. 69)

5. Viva a beleza do Pacífico Mexicano explorando a ensolarada Ensenada. Lá, você vai ver as praias mais cheias de luz, perfeitas para andar a cavalo e bronzear-se.

(REVISTA Carnival, 2003, p. 71)

\section{Tão selvagem e tão belo}

Este é o Alasca, a última fronteira da América, quilômetros que se estendem a perder de vista entre vales de verdes profundos, fiordes cercados por escarpas montanhosas e rios onde se encontram os maiores cardumes de salmão, tudo isso confere ao Alasca uma qualidade singular e cheia de magia. $[\ldots]$

(REVISTA Carnival, 2003, p. 75)

Os seis trechos aqui enunciados estão tratando unicamente das questões do condicionamento do discurso em relação às viagens turísticas. Entretanto, quando se trata do meio urbano, temos um condicionamento diferente:

1. Um mundo de opções!

Um dos inúmeros prazeres de se tirar férias a bordo de um dos "Fun Ships" da Carnival é contar com uma série de opções de acomodações, capazes de 
atender a qualquer orçamento. Nos navios CARNIVAL DESTINY, CARNIVAL TRIUMPH E CARNIVAL VICTORY, mais de 60\% das cabines são externas; destas, mais de $60 \%$ possuem terraço privativo. Nos queremos que você viaje ao estilo Carnival. A sua cabine tem todo o conforto de um lar, além do serviço especial a qualquer hora do dia ou da noite.

Como foi visto nos anúncios, o meio urbano faz com que o veículo seja o próprio folder turístico, uma vez que atinge à classe média urbana (de média para alta). É ela que, no presente momento, apresenta maior perplexidade diante da realidade retratada pelo folheto. Por se situar numa faixa social e economicamente fronteiriça - de um lado o nível crescente das expectativas geradas e nutridas pela sociedade de consumo - nesse caso, o leitor-turista; de outro, a ameaça de queda do padrão de vida gerada por um momento sócio-econômico bastante complexo - a classe média-alta se tornas um mercado particularmente sensível a esse tipo de apelo.

Dessa forma, à beleza e sedução do folheto subjaz uma proposta de relação do consumidor (o leitor-turista) com os objetos, com as outras pessoas, consigo próprio e com o mundo que o rodeia. A publicidade se constitui num fenômeno de sentido. Desloca o objeto de sua função de uso para uma função de signo, atribuindo-Ihe uma valor de troca simbólica. Esses objetos cristalizam valores que são os da classe dominante e a que as demais classes sociais aspiram no imperativo de seu movimento ascendente. Entretanto, realizado por meio da posse dos objetos, esse movimento é ilusório. O consumo, que o anúncio e a publicidade estimulam, surge como uma das formas de o ser humano suprir a falta de uma atividade produtiva criadora, camuflando a ausência de uma efetiva participação social e favorecendo a manutenção das relações de dominação. 


\section{CONSIDERAÇÕES FINAIS}

Há de se inferir várias questões na abordagem até desenvolvida. Uma primeira seria de indicar que a análise do discurso de Chain Perelman é fundamental para qualquer análise em se faça presente o texto escrito e/ou as imagens com conotações e/ou apelações textuais bastante acentuadas. Uma segunda diz respeito à prática de leitura como forma de sedução, o que, na verdade, foi defendido exasperadamente ao longo desse trabalho.

Outrossim, aspectos como os níveis da argumentação nos folhetos, o ponto de partida da argumentação e adaptação dos folhetos com vistas à argumentação foram fundamentais para se averiguar como os níveis discursivos sob a ótica de Perelman desenvolvem mecanismos de controle persuasivo, até mesmo quando se tratava apenas da miscigenação de texto-imagem.

As questões relativas aos folhetos como forma de discurso foram desenvolvidas em forma de análise de fragmentos textuais, revelando muitas características persuasivas já largamente abordadas por Chain Perelman em seu TRATADO DE ARGUMENTAÇÃO: A Nova Retórica.

Nos capítulos relativos às técnicas argumentativas usadas nos folhetos e folders analisados, os argumentos baseados na estrutura do real dos folhetos e as ligações que fundamentam a estrutura do real, procurou-se delimitar objetos de análise que fossem significativos para a aplicabilidade da análise do discurso nos folhetos turísticos a fim de esclarecer como o texto, em especial o do turismo, e ainda as imagens associadas ao texto, influenciam, de forma ou de outra, as escolhas do leitor, a que se convencionou de chamar de leitor-turista ao longo dessa monografia.

Nos capítulos as dissociações das noções e a interação dos argumentos, procurou-se averiguar como a utilização das formas verbais influenciam uma decisão 
de um leitor-turista, associados com as análises das formas de discurso nos folhetos. Os processos de ruptura de ligação e dissociação foram destacados com o objetivo de compreender a ligação entre expressão, definição e dissociação nos folhetos.

Os aspectos de interação e força dos argumentos, unificados com à questão da ordem e persuasão discursivas, evidenciaram, com muita propriedade, os resultados retirados das inúmeras análises de vários folhetos e folders da revista Carnival e outras.

Não obstante, outras questões levantadas no início do trabalho monográfico acabaram por se confirmar parcial ou integralmente. Em conseqüência, procurou-se estabelecer as seguintes hipóteses aplicadas ao estudo de caso dos 208 folhetos e folders de turismo selecionados da revista:

a) A argumentação, que tem por finalidade provocar ou aumentar a adesão de um público - aqui contextualiza-se com o turismo - por meio do discurso, apresentou argumentos universalizantes, sobretudo no que dizem respeito ao nível de discursividade constatados nos folhetos. Entenda-se, aqui, que essa hipótese, na medida do possível, concretizouse, haja vista termos chegado à conclusão de que realmente o discurso, assim como preconizado por Perelman, universaliza-se à medida que o leitor-turista ${ }^{10}$ deixa-se seduzir ora pelo vocabulário adjetivado dos textos, ora pelas belas imagens presentes juntamente com os folhetos escolhidos.

b) Na hipótese "o orador que produz o discurso é usado para dirigir nossa ação e para influenciar a dos outros?" Verificou-se que tal prerrogativa confirmou-se plenamente, ainda mais porque o leitor-turista deixava-se influenciar naturalmente pelo chamados níveis de argumentação, resultando nos altos índices de persuasão em detrimento da compra de pacotes turísticos de navio.

\footnotetext{
${ }^{10}$ Que, desde o início do trabalho, assim fora designado.
} 
c) Em relação à hipótese "o público que pode ser universal ou particular e cujos fatores psicológicos, afetivos, sócio-culturais e ideológicos devem ser levados em consideração ou não?" Tais premissas não foram satisfatoriamente sustentadas só pelos argumentos contidos no TRATADO DE ARGUMENTAÇÃO: A Nova Retórica. Isso aconteceu porque, para Perelman, os principais fatores preponderantes aqui foram os lingüísticos e, depois, os discursivos.

Por essa razão, talvez não tenhamos, nessa hipótese em particular, alcançado nosso objetivo, mas, pelo menos, ficou o desejo de mostrar o texto publicitário do turismo oriundo de revistas, que pertenciam a agências de turismo do Distrito Federal.

Por derradeiro, tivemos a intenção de constatar, também, que a existência de uma argumentação, que não seja nem coerciva nem arbitrária, confere um sentido à liberdade humana de livre escolha, condição de exercício de uma escolha racional. Se a liberdade fosse apenas adesão necessária a uma ordem natural previamente dada, excluiria qualquer possibilidade de escolha; se o exercício da liberdade não fosse fundamentado em razões, toda escolha seria irracional e se reduziria a uma decisão arbitrária atuando num vazio intelectual imenso.

Graças à possibilidade de uma argumentação que forneça razões, mas razões não-coercivas, é que é possível escapar ao dilema: adesão a uma verdade objetiva e mercadológica - a dos folhetos e folders - e universalmente válida, ou recurso à sugestão para fazer que se admitam suas opiniões e decisões. O que uma lógica dos juízos de valor tentou em vão fornecer a teoria da argumentação contribuirá pra elaborar, e isto a partir de uma análise dessas formas de raciocínio que, embora indispensáveis na prática, foram menosprezadas, depois de Descartes, pelos lógicos e teóricos do conhecimento e, é claro, pelos da análise do discurso. 


\section{REFERÊNCIAS BIBLIOGRÁFICAS}

ANDRADE, J.V. Turismo e dimensões, São Paulo, Ática, 1998.

Turismo: Fundamentos e dimensões, São Paulo, Ática, 2001.

ANDRADE, José Vicente de. Os antecedentes do turismo. Belo Horizonte, Factur, 1976.

Nacional de Turismo, 1976.

O turismo e a cultura. Belo Horizonte, IV Congresso

Horizonte, IMCAT, 1985.

. Síntese histórica da hotelaria mundial. Belo

BARRETO, Margarita. Planejamento e organização de turismo. Campinas: Papirus, 1991.

Papirus, 1995.

Manual de iniciação ao estudo do turismo. Campinas:

BARROS, D.L.P.B e FIORIN, J.L. Dialogismo, polifonia, intertextualidade, São Paulo, EDUSP, 1994.

BARROS, Luiz Martins Monteiro de. Aspecto e tempo na flexão do verbo português. Niterói, Universidade Federal Fluminense, 1974. Dissertação de Mestrado.

Teoria e Semiótica do texto, São Paulo, 1997.

BENI, Mário Carlos. Análise estrutural do turismo. 6a ed., São Paulo: Editora SENAC, São Paulo, 2001.

BRANDÃO, H.H.N. Introdução à Análise do Discurso, Campinas, Editora da UNICAMP, 1999.

CAMARA JÚNIOR, J. Matoso. Dicionário de Lingüística e gramática: referente às língua portuguesa, 13ª ed., Petrópolis, Vozes, 1986.

CELSO, Pedro Luft. Minidicionário Luft. 18ª ed., São Paulo, Ave Maria, 1999. 
COROA, Maria Luisa M.S. O tempo nos verbos do português: uma introdução à sua interpretação semântica. Brasília: Thesaurus, 1985.

COSTA, Sônia Bastos Borba. O aspecto em português, São Paulo: Contexto, 2002.

DUCROT, O. O dizer e o dito, Campinas, Pontes, 1999.

1998.

. Provar e dizer, tradução Brasileira, Global Universitária, São Paulo,

FERRAZ, Joandre Antônio. Regime jurídico do turismo. Campinas: Papirus, 1992.

FIORIN, J.L. As astúcias da enunciação: as categorias de pessoa, espaço e tempo, São Paulo, Ática, 1999.

GUIMARAES, E. Texto e Argumentação: um estudo de conjugações do Português, Campinas, Pontes, 1997.

ILARI, Rodolfo. A expressão do tempo em Português, São Paulo, EDUC, 1997.

Campinas: Editora UNICAMP 1992.

Perspectiva funcional da frase portuguesa. 2 ed. Revista.

Introdução ao turismo/direção e redação Amparo Sancho. Traduzido por Dolores Martin Rodrigues Córner, São Paulo, Roca, 2001.

LOBATO, Lúcia M. P. "Os verbos auxiliares em português contemporâneo. Critérios de auxiliaridade”. In: Análise lingüística. Petrópolis, Vozes, 1975.

MATEUS, Maria Helena Mirta et alii. Gramática da língua portuguesa; elementos para a descrição da estrutura, funcionamento e uso do português actual. Coimbra, Almedina, 1983.

MORAES, Denis de. (org.). Globalização, mídia e cultura contemporânea. Campo Grande: Letra Livre, 1997.

NAISBITT, John. Paradoxo global. Rio de Janeiro: Campus, 1994.

ORLANDI, Eni Puccinelli. Análise do discurso: princípios e procedimentos, Campinas, São Paulo, Pontes, 2000. 
PAIVA-BÓLEO, Manuel. O pretérito e o perfeito em português, em confronto com as outras línguas românicas. Coimbra, Imprensa da Universidade, 1986.

PERELMAN, Chain. O Império retórico: Retórica e Argumentação, Porto, Ed. Asa, 1996.

PONTES, Eunice. Verbos auxiliares em português. Petrópolis, Vozes, 1973.

RUSCHMANN, Doris. Marketing turístico: um enfoque promocional. Campinas: Papirus, 1991.

SANTOS, Abílio de Jesus dos. Aspecto verbal e sua aplicação ao português. Separata de ROMANITAS, 8, 1967.

THEOBALD, William F. (org.). Turismo global. São Paulo: Editora SENAC, São Paulo, 2001.

STEIFF et alii. Os mitos da publicidade. Trad. Hilton F. Japiassu. Petrópolis. Vozes, 1974.

TRAVAGLIA, Luís Carlos. 0 aspecto verbal no português. Ed. Revisada. Uberlândia: Universidade Federal de Uberlândia, 1985.

O aspecto verbal no português: a categoria e sua expressão. Universidade Federal de Uberlândia. Centro de Ciências Humanas e Artes, 1981.

TRIGO, Luiz Gonzaga Godoi. Turismo básico. 6ª ed., revisada e ampliada, São Paulo, SENAC, 2002.

VESTERGAARD, Torben. A linguagem da propaganda. $1^{\mathrm{a}}$ ed., São Paulo, Martins, 1988. 
ANEXOS 
ANEXO 1 


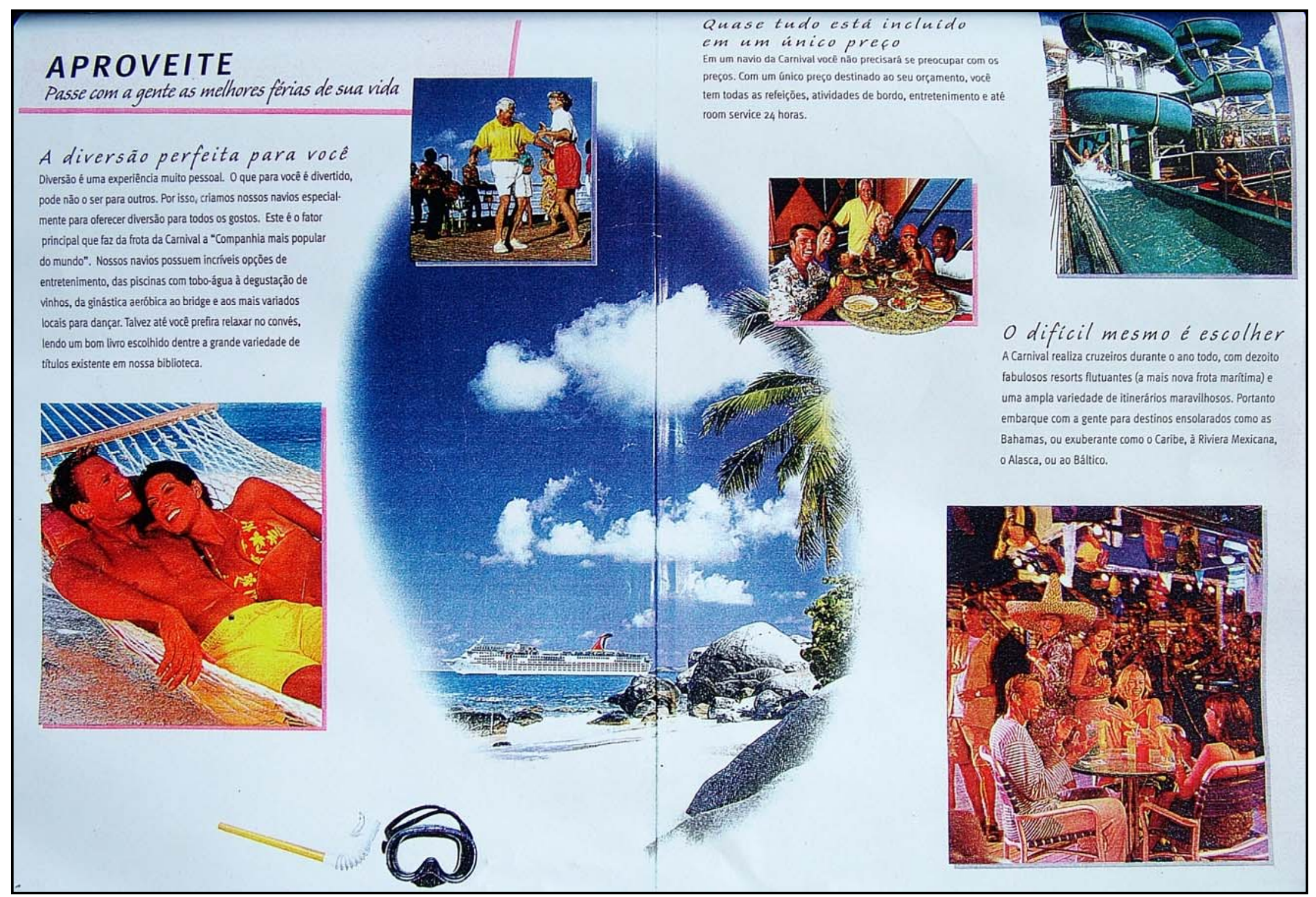


ANEXO 2 


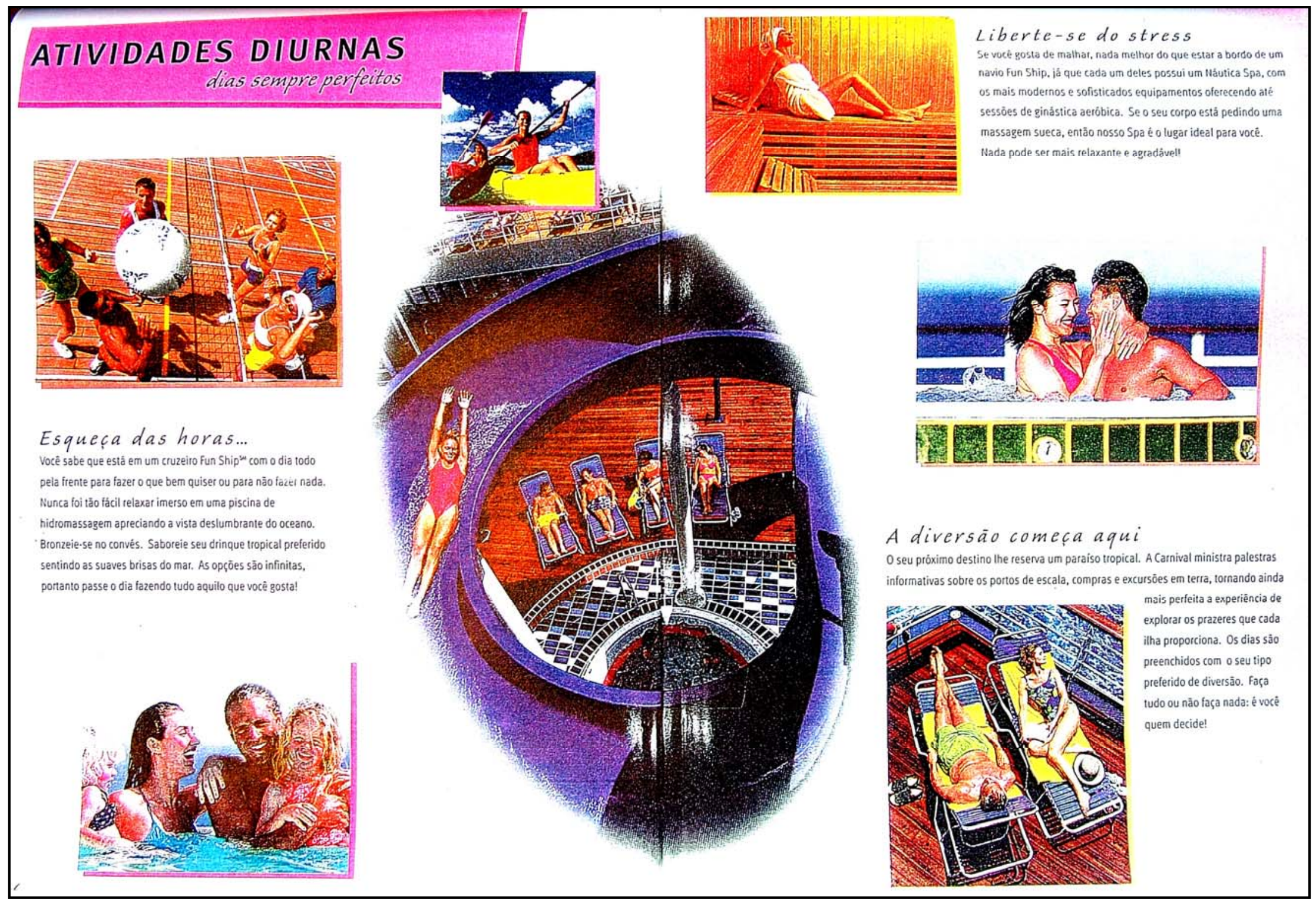


ANEXO 3 


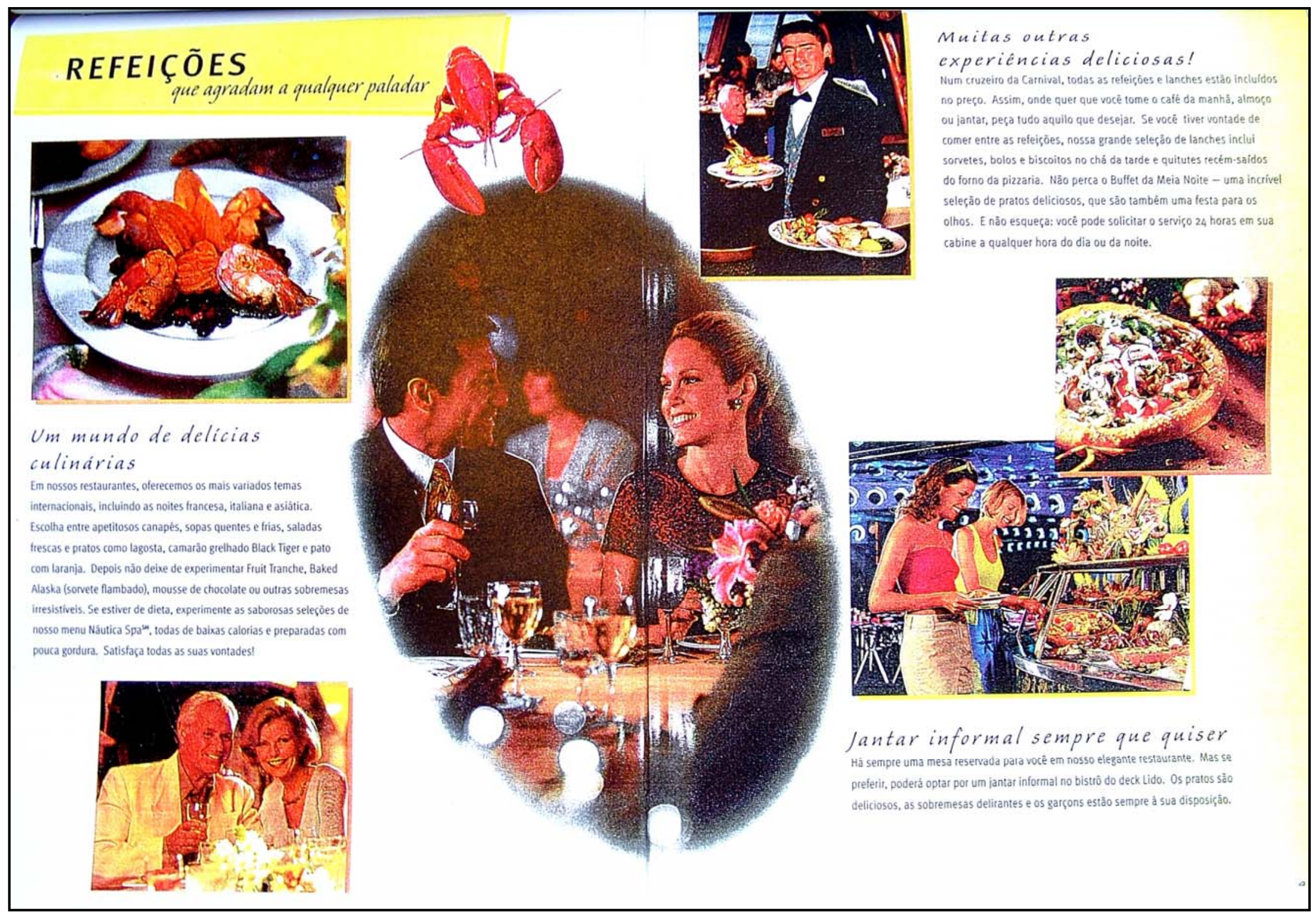


ANEXO 4 


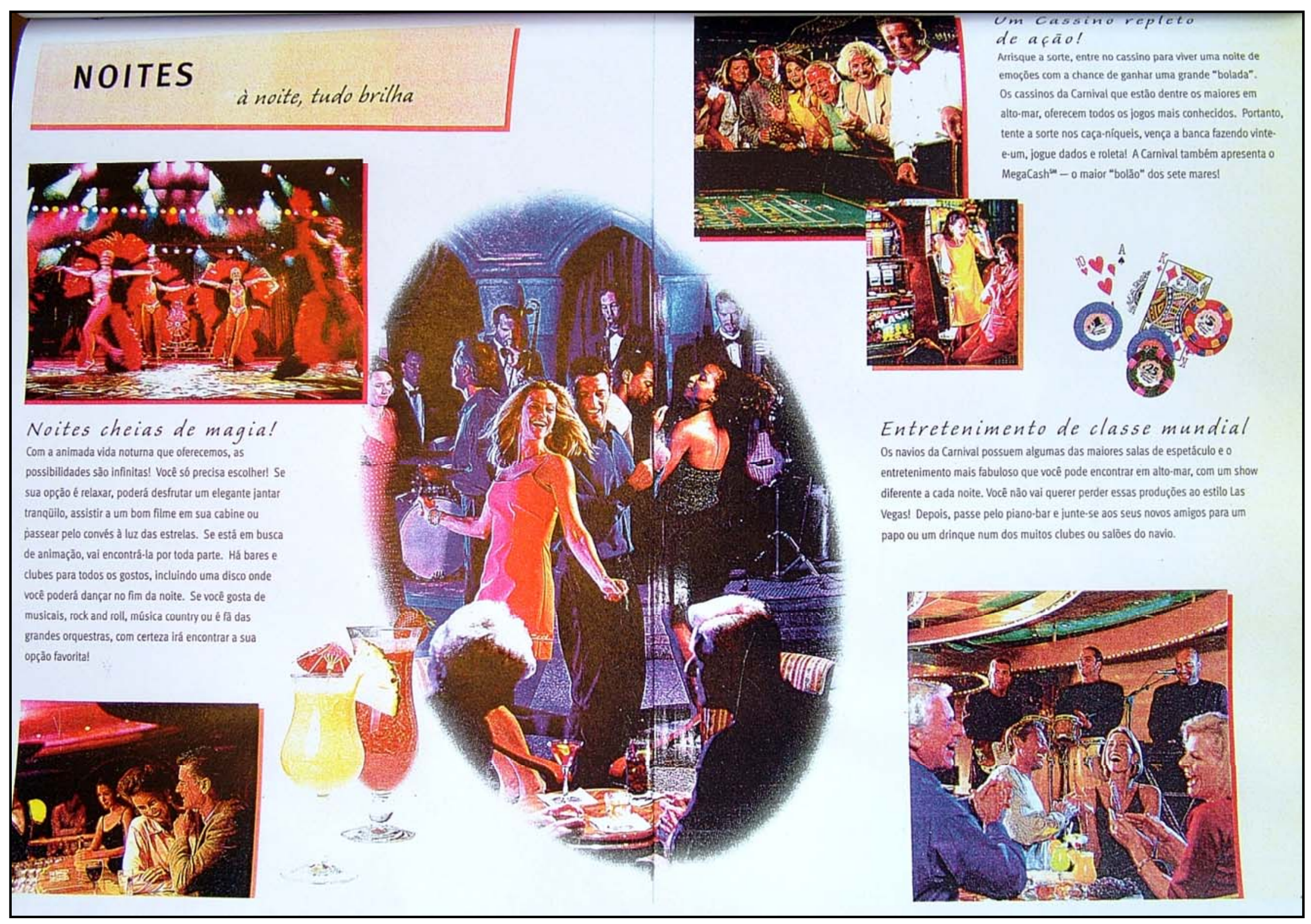


ANEXO 5 


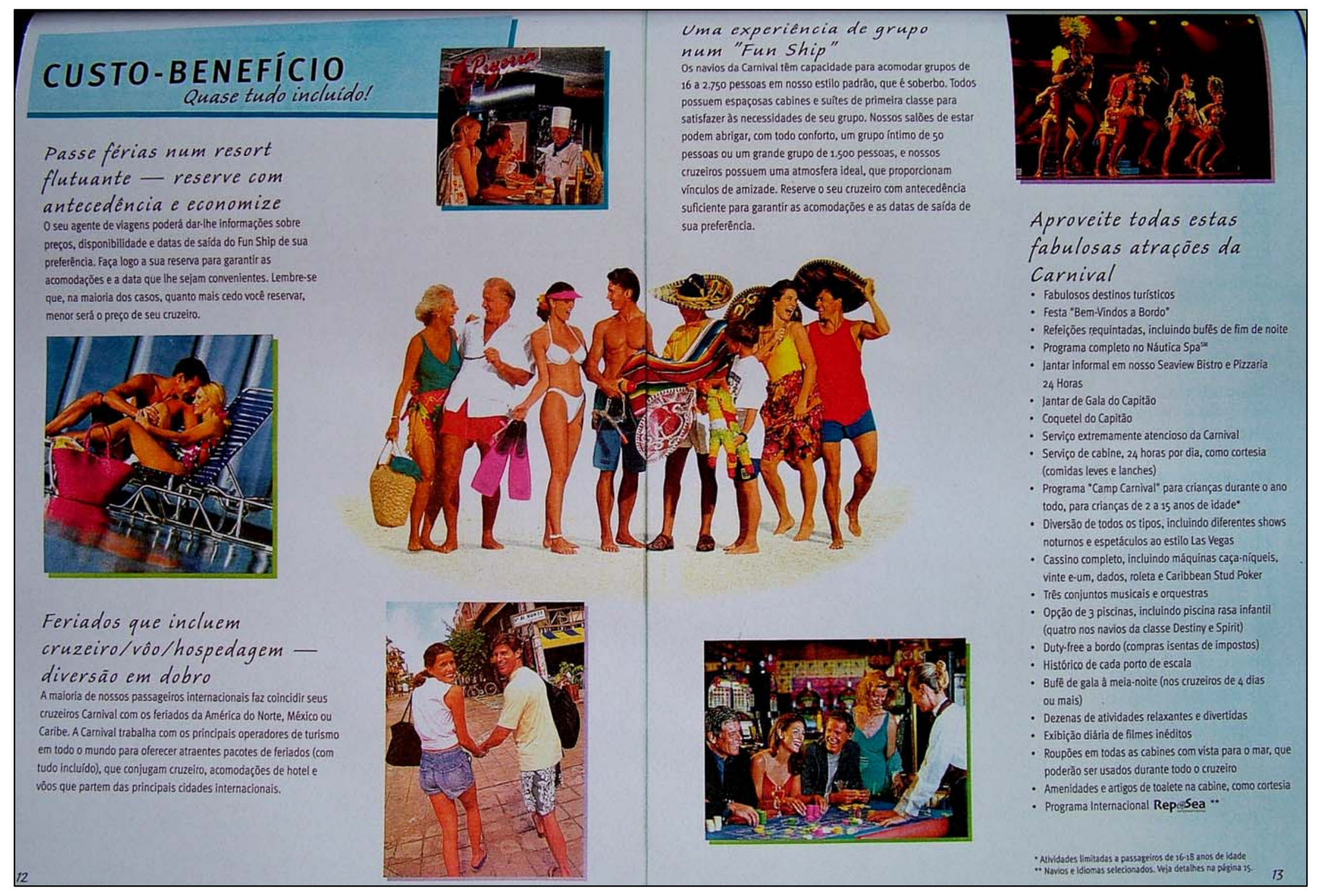


ANEXO 6 


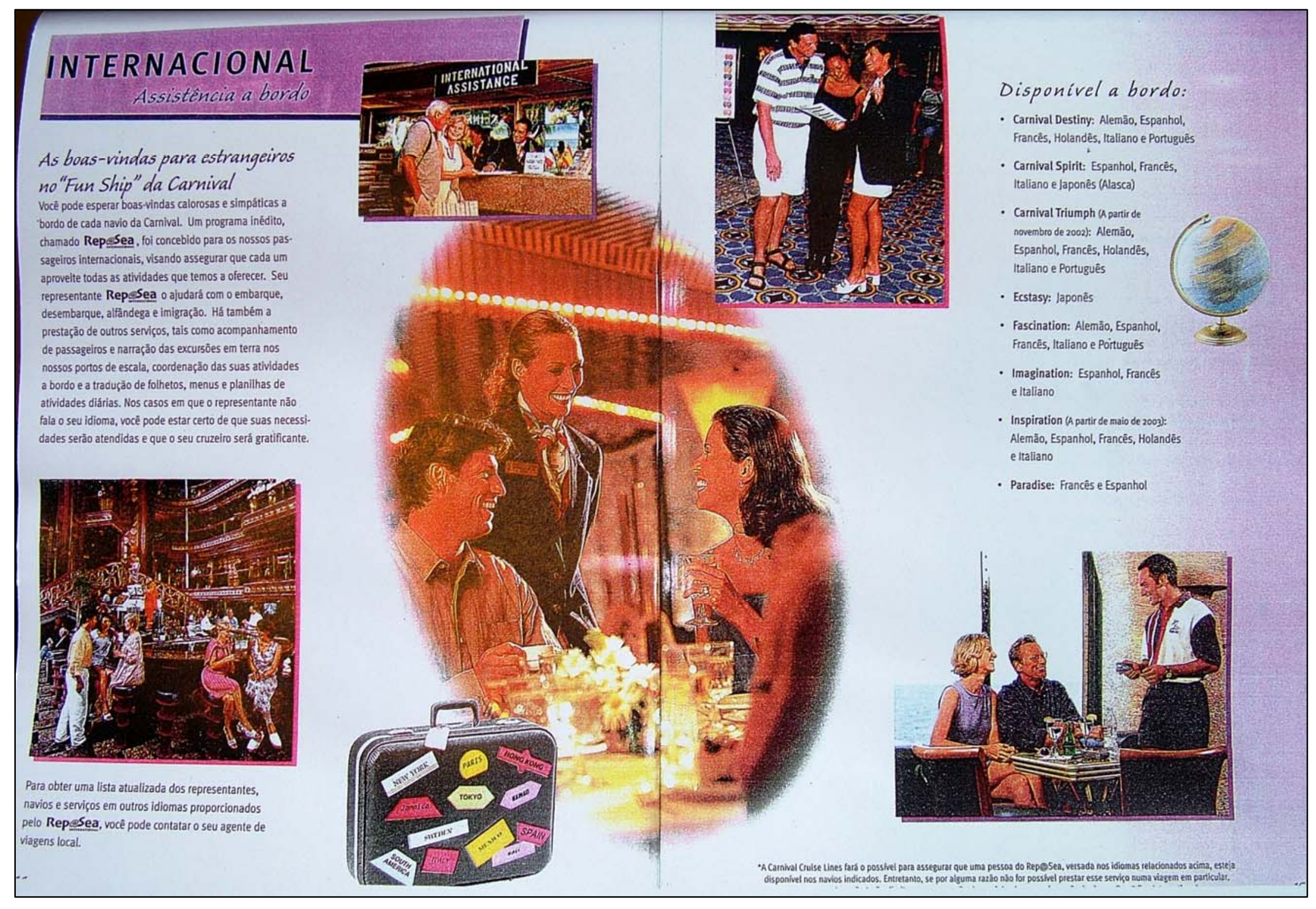


ANEXO 7 


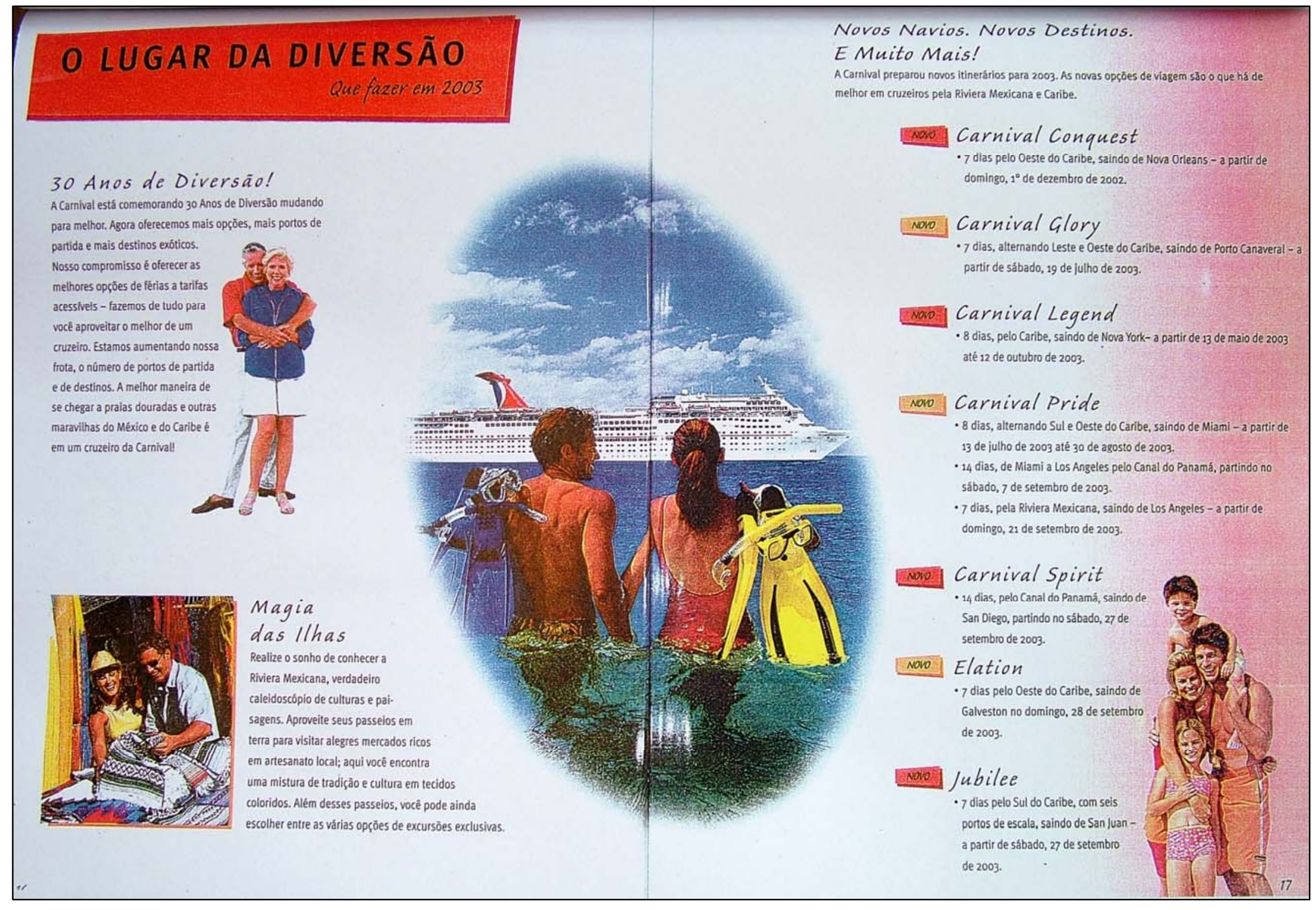


ANEXO 8 


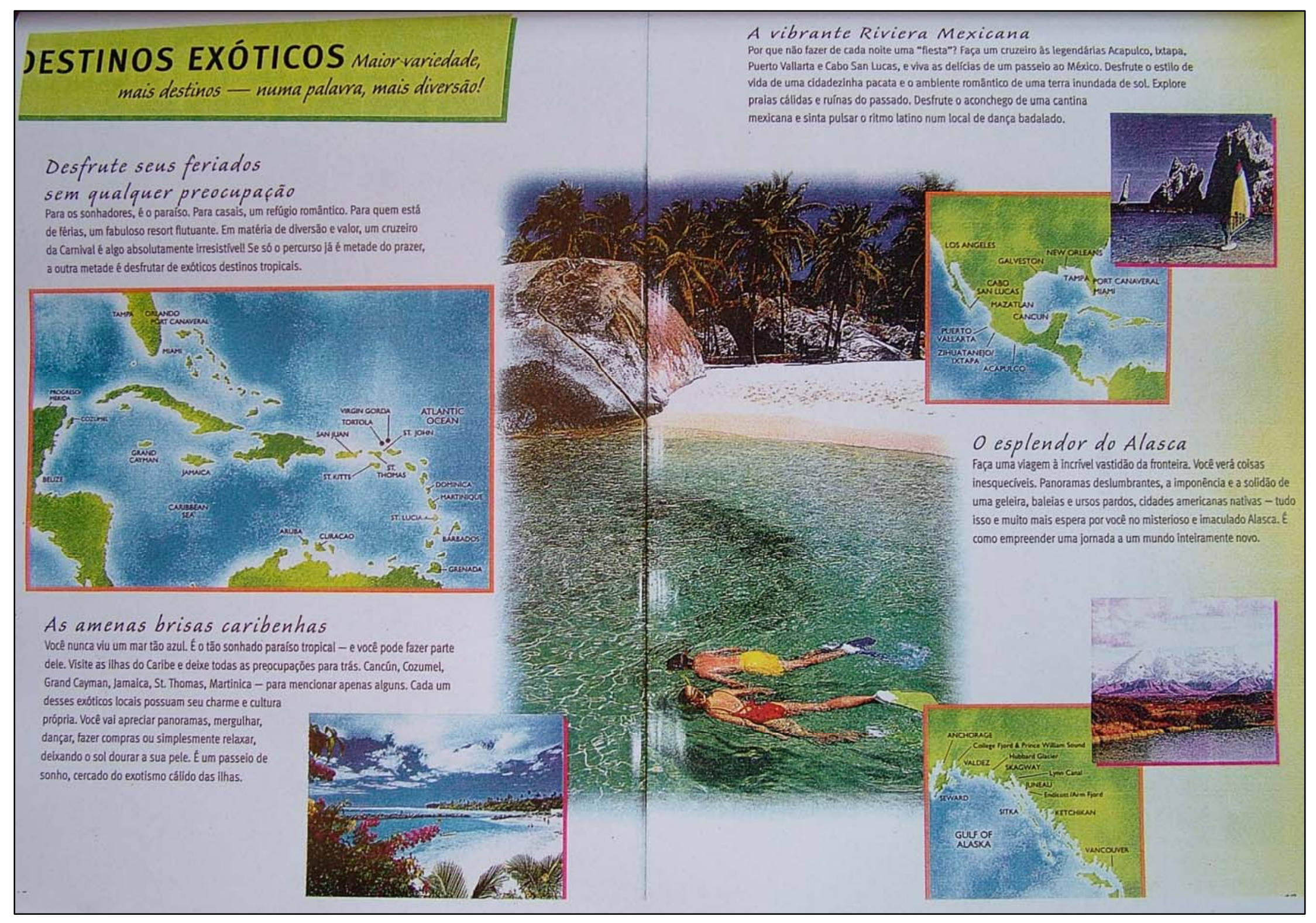


ANEXO 9 


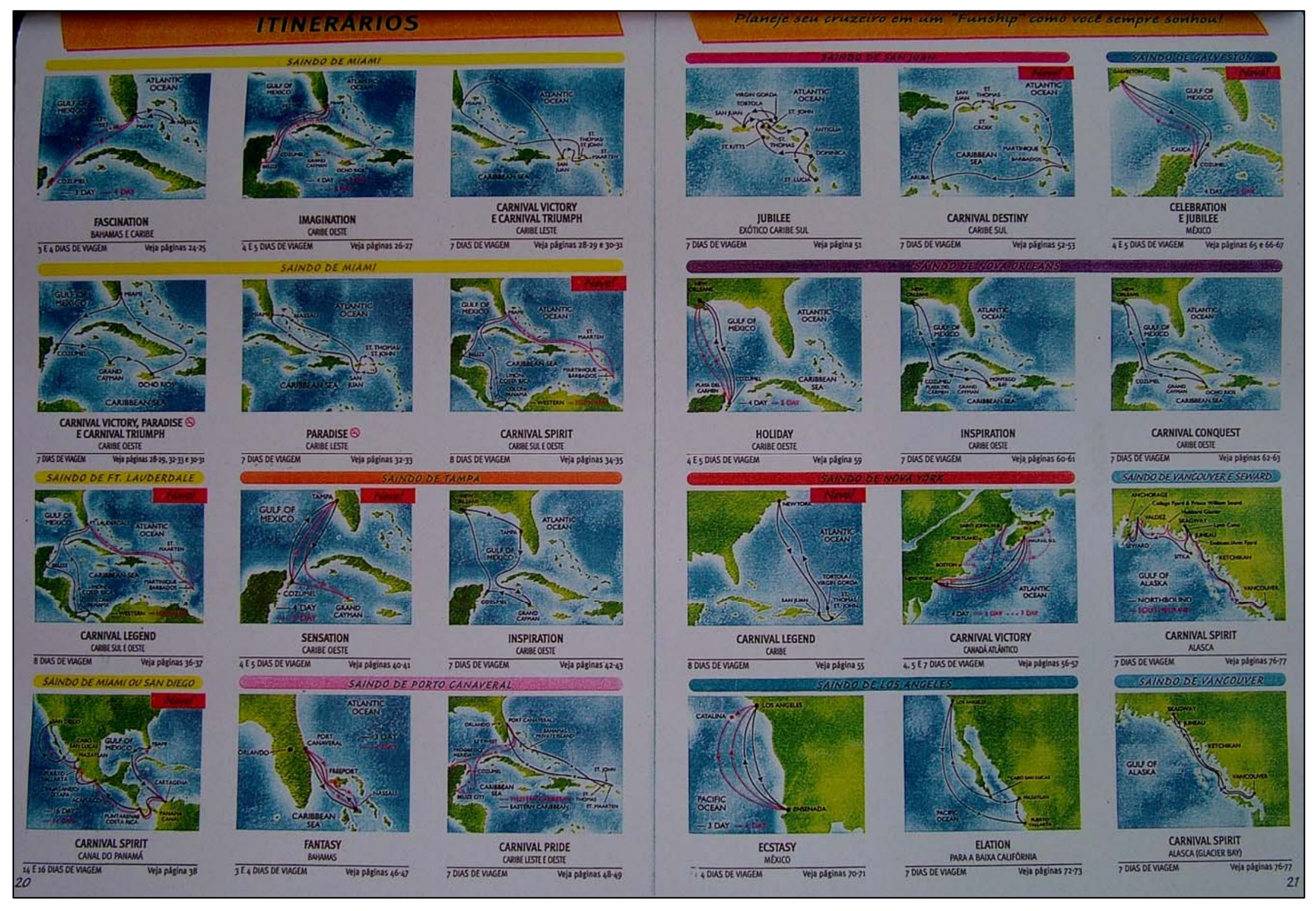


ANEXO 10 


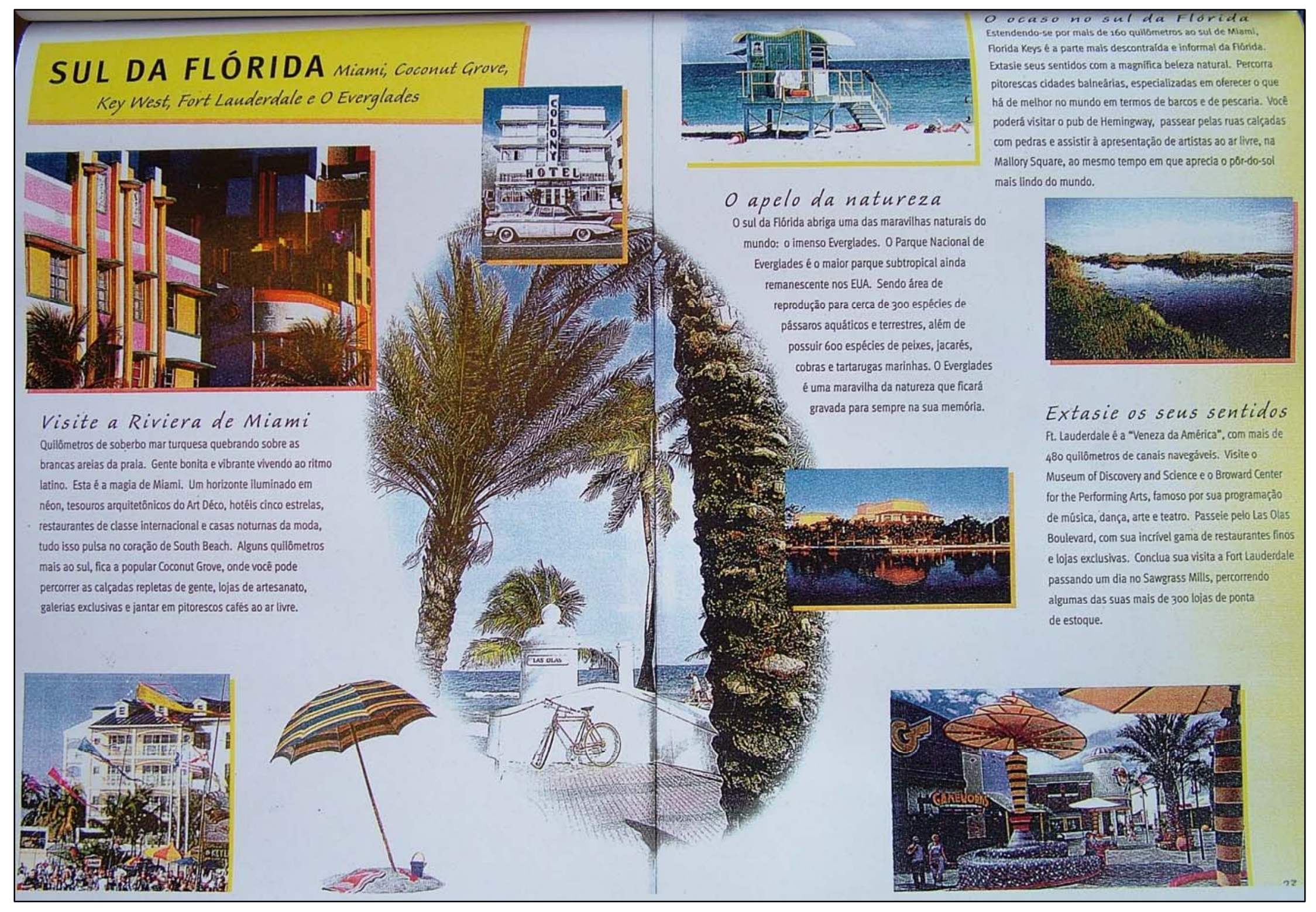


ANEXO 11 


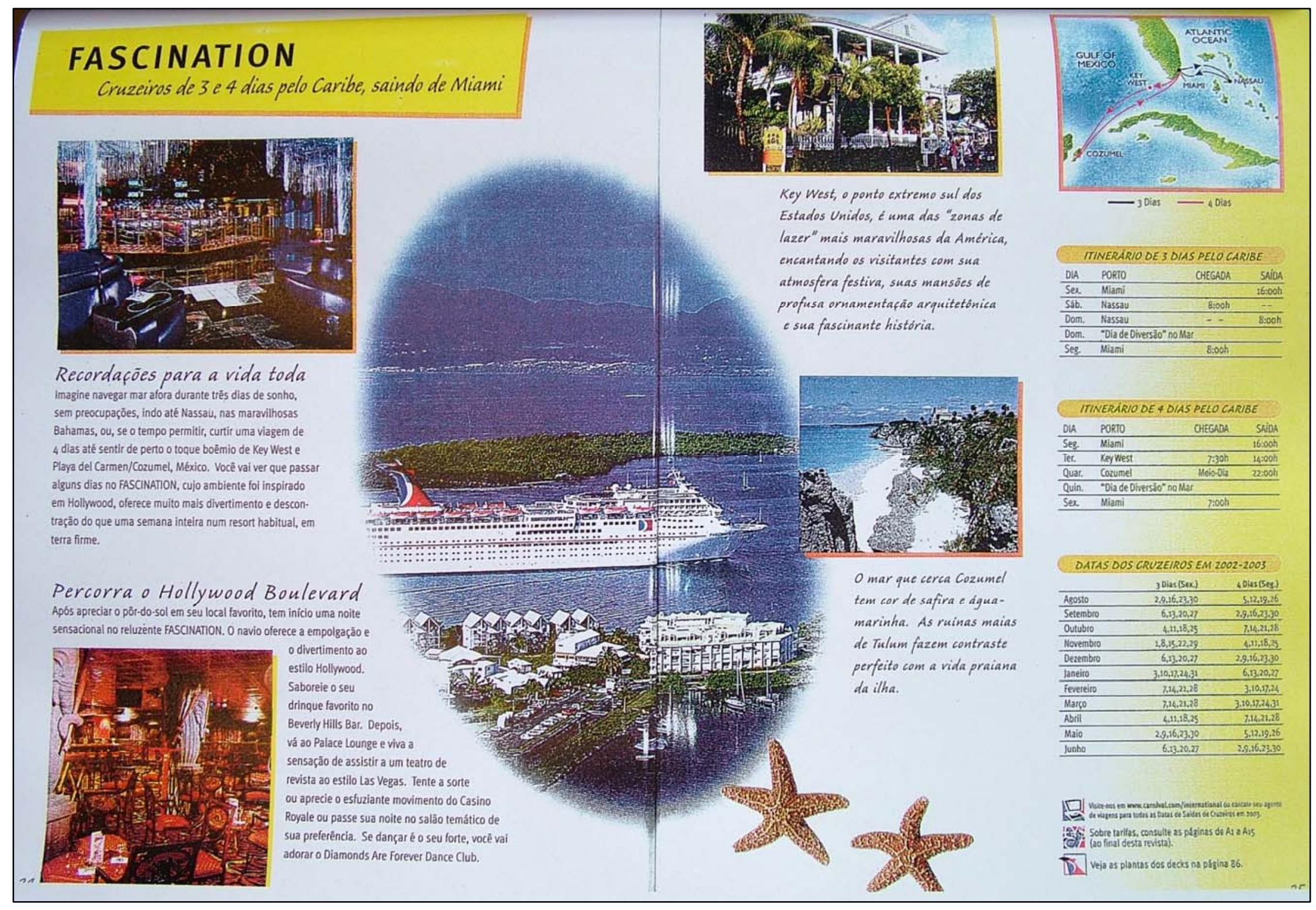


ANEXO 12 


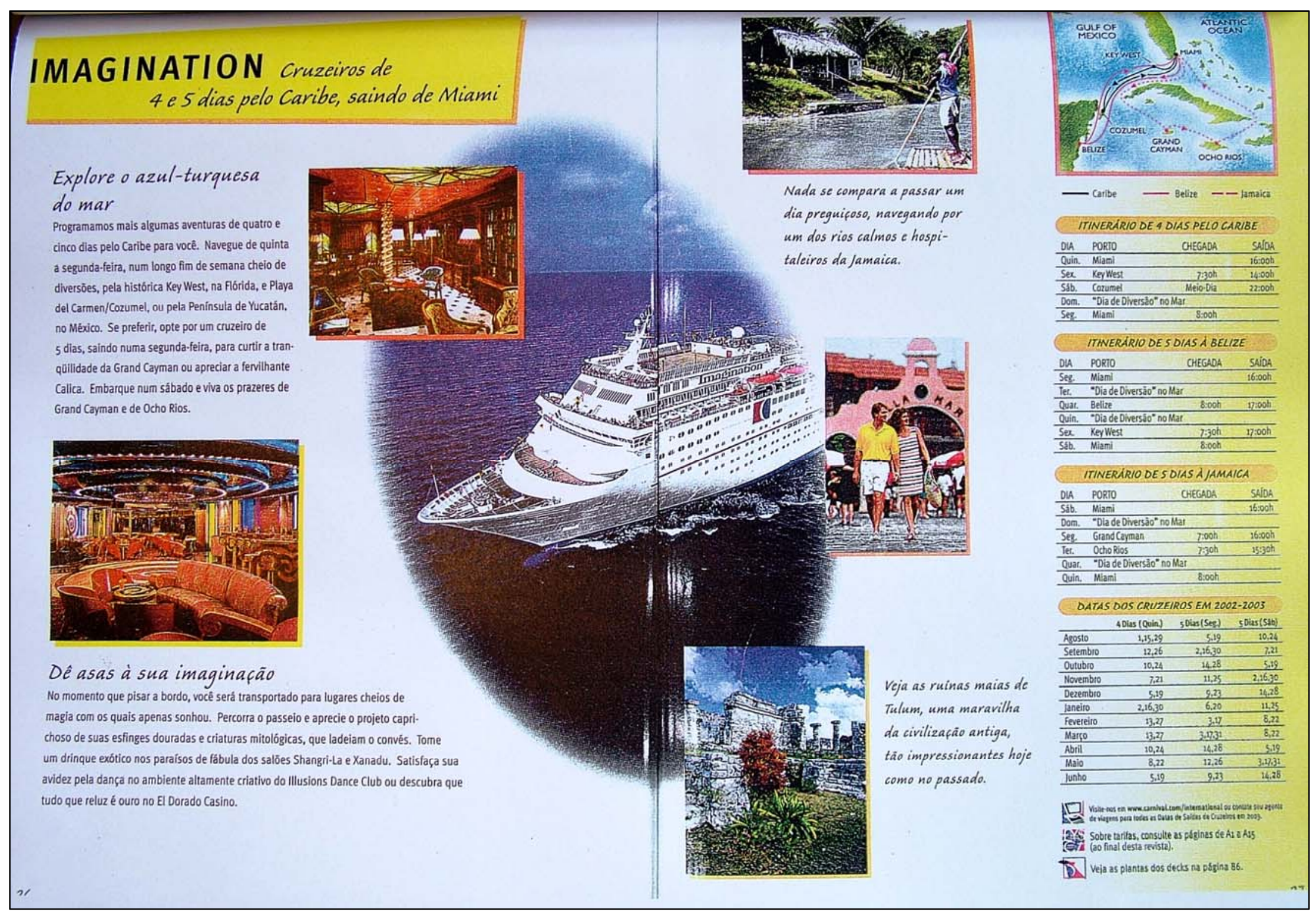


NEXO 13 


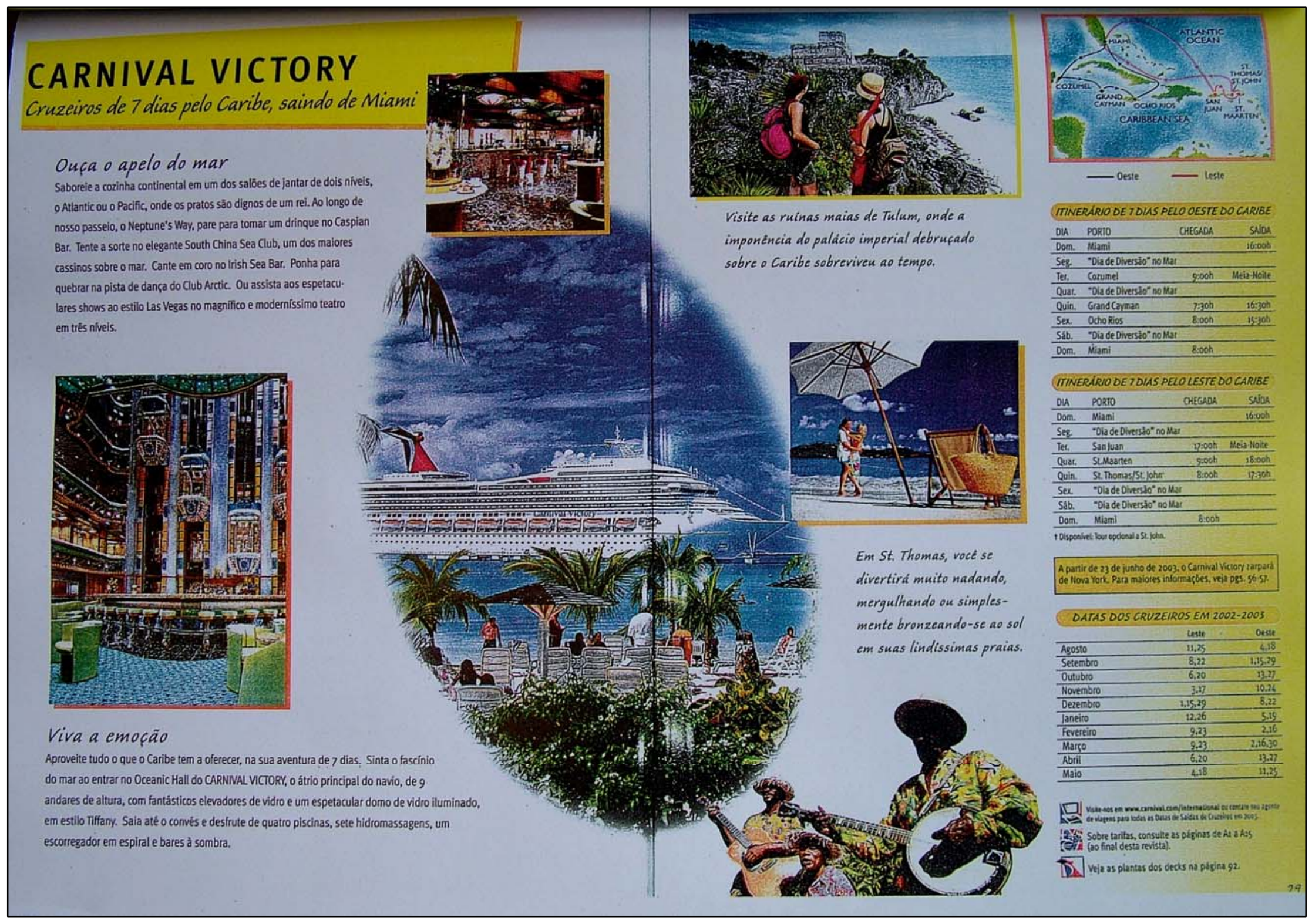


ANEXO 14 


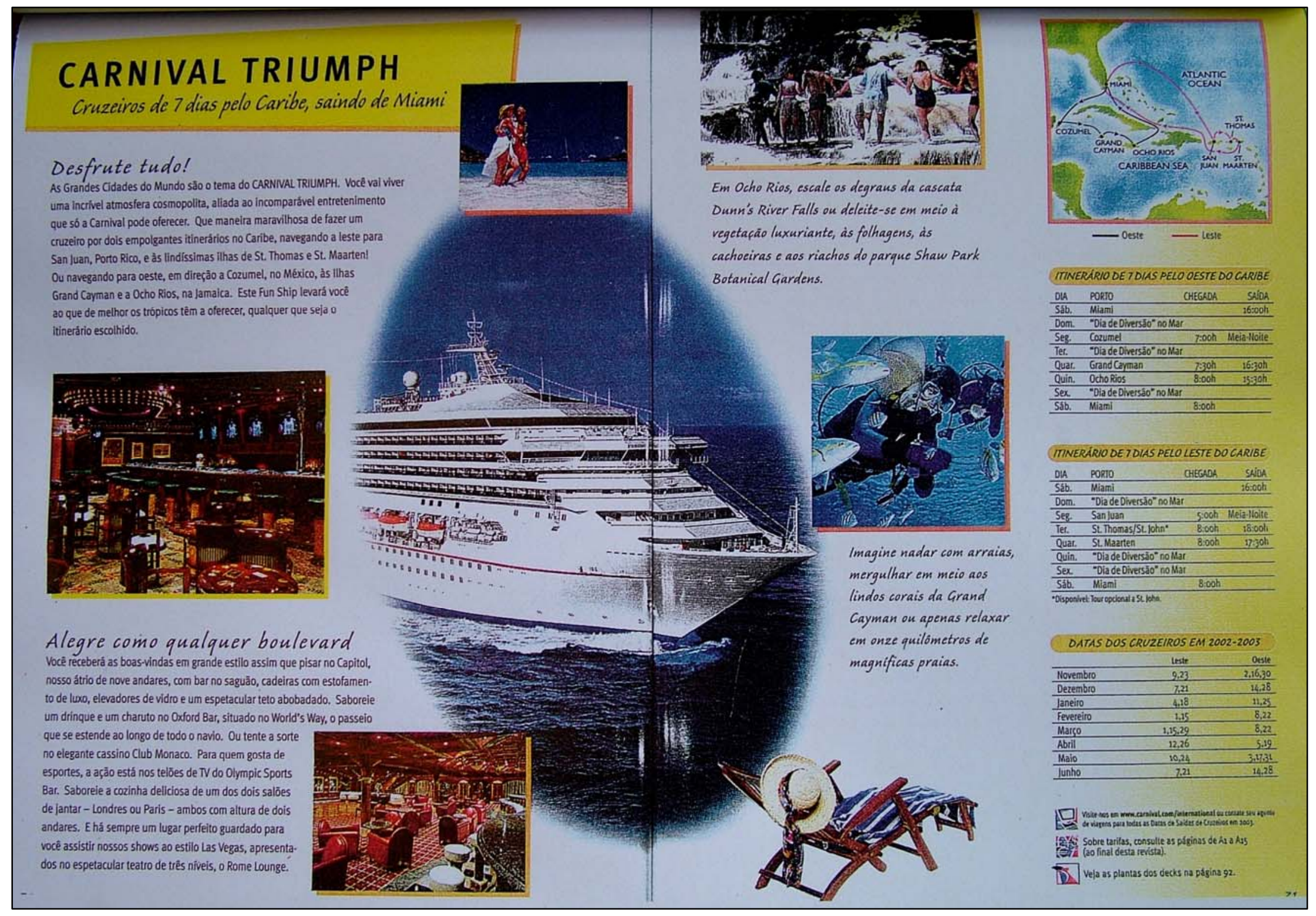


ANEXO 15 


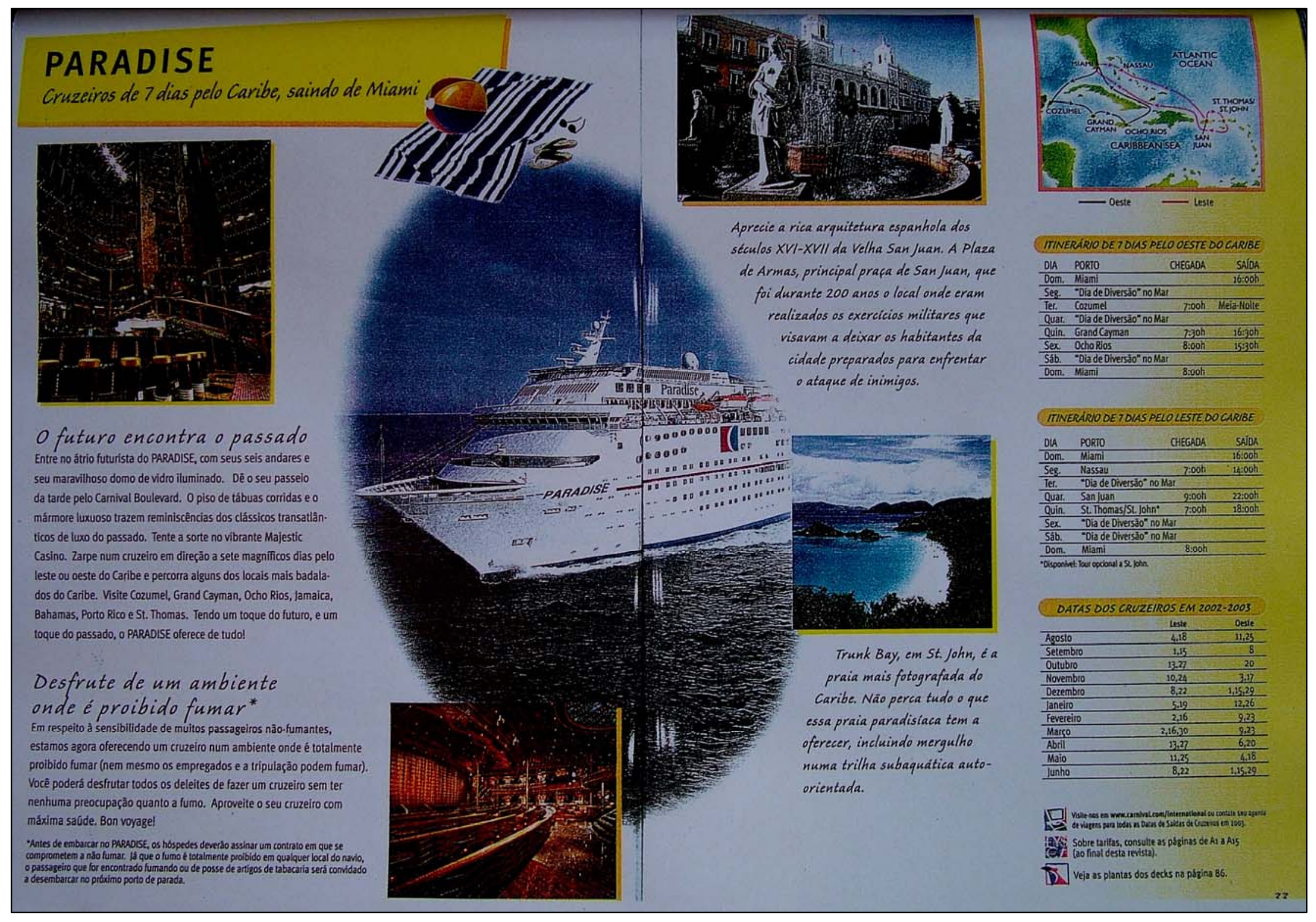




\section{ANEXO 16}


CARNIVAL SPIRIT

Cruzeiros de 8 dias pelo exótico Caribe, saindo de Miami

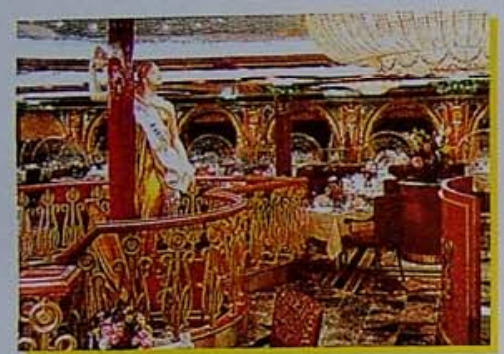

Participe de uma

exótica aventura

Viaje de Miami para os destinos mais exóticos, a bordo do

Inctivel CARNNAL SPIRTI. Criamos uma inovadora classe de navio

- a classe 'Spirit'. Este navio, novo e exclusivo, foi projetado

com $80 \%$ das cabines oferecendo uma deslumbrante vista para

o mar, sendo que dessas cabines outros $80 \%$ possuem terraço

privativo. A bordo deste navio, você pode fazer cruzeiros a destinos

mais remotos da parte sul e ocidental do Caribe do que nunca,

visitando exóticos paraísos tropicais. Você vai passar oito dias

gloriosos navegando para alguns dos lugares mais belos do planeta.

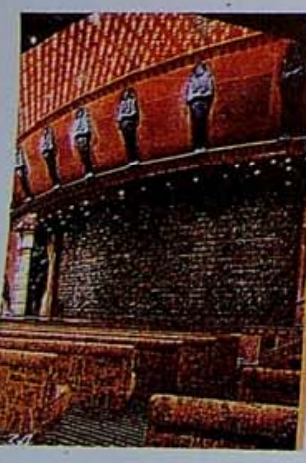

Entre nesse espirito

você vai curtir dias dourados, em que vaì

esquecer o estresse. Acorde com energia e

disposiç̧̄o para malhar em nossa academia, total-

mente equipada, enquanto aprecia a beleza do Mar do

Caribe. Ou, se preferit, você pode dispensar a malhaçāo e

partí direto para o convés - o local ideal para desfrutar a refres.

cante brisa marinha e um drinque tropical. Guarde suas energias para a

noite palpitante que viverá a bordo, comeşando por um jantar delicioso no

restaurante Empire e, em seguida, dançando ao ritmo vibrante do clube

noturno Dancin' Dance Club.
Em Barbados, visite St. Nicholas Abbey, uma magnifica histórica mansão em Estilo james I.

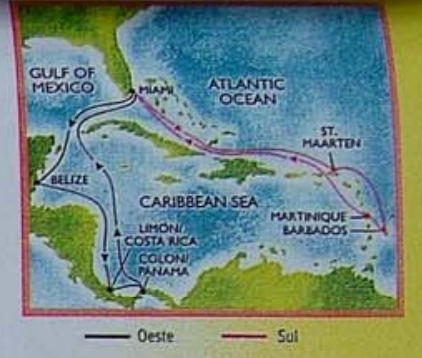

ITINERIRIO DE S OIAS PELO SUL DO CARBBE

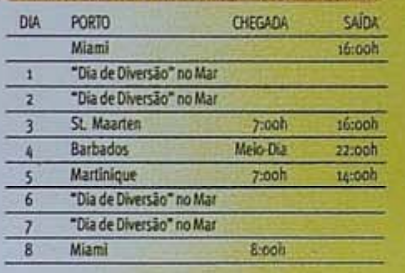

IINERARIO DE S DIAS PELOO OESTE DO CARIBE

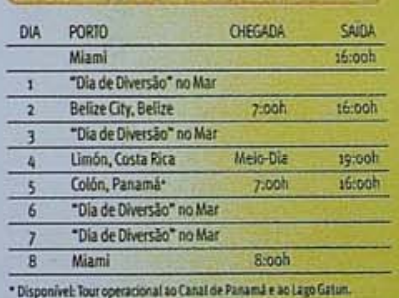

cercado pela beleza natural da

Costa Rica, com sen clima ideal c sua atmosfera romantica.

DATAS DOS CRUZEIROS EM 2002-2003

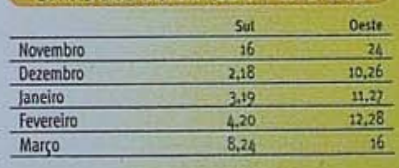

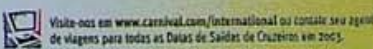

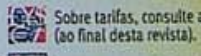

D. Veja as plantas dos dects na posina aE 
ANEXO 17 


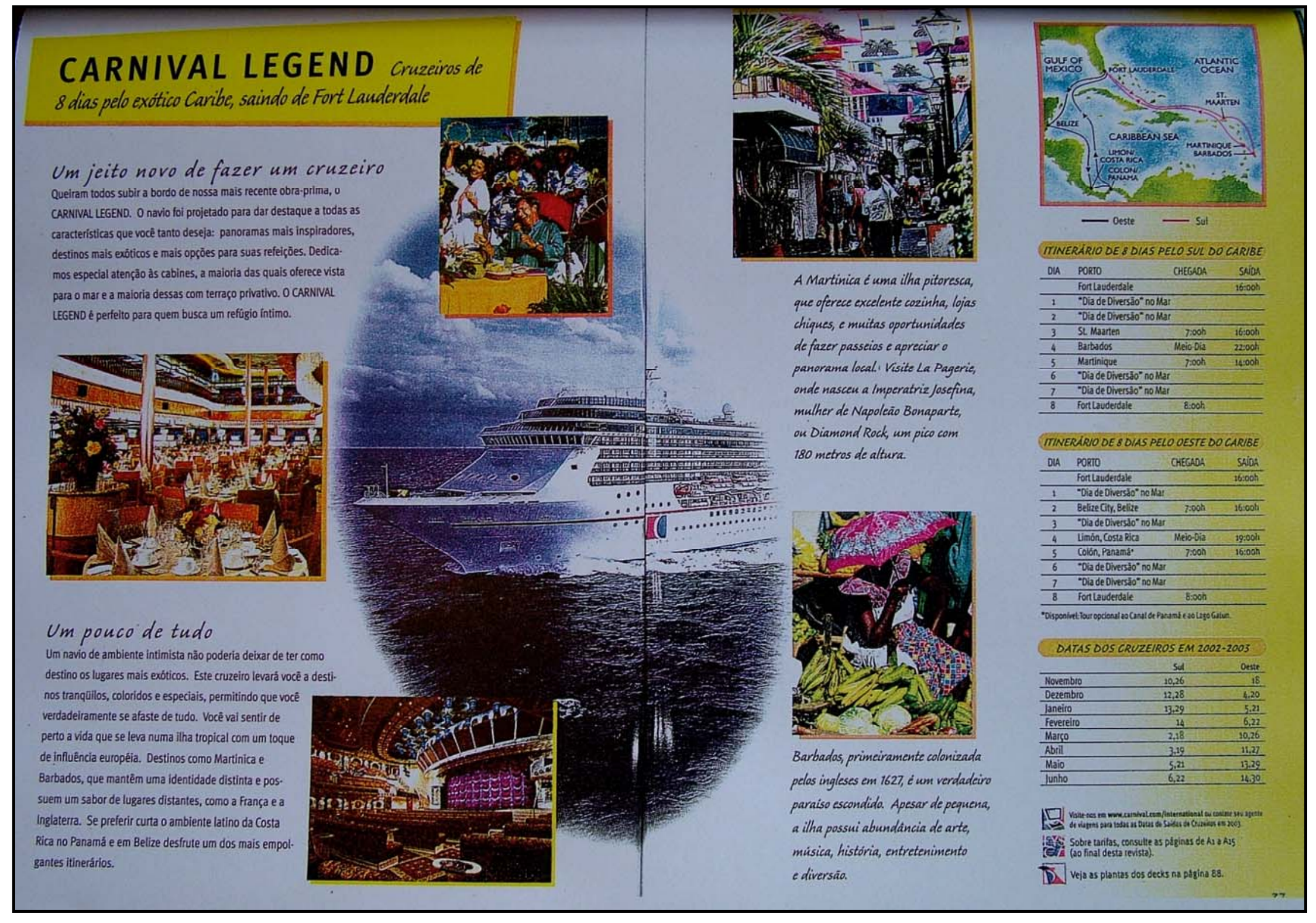


ANEXO 18 


\section{CARNIVAL SPIRIT}

Cruzeiros de 14 e 16 dias ao Panamá, saindo de Miami e San Diego

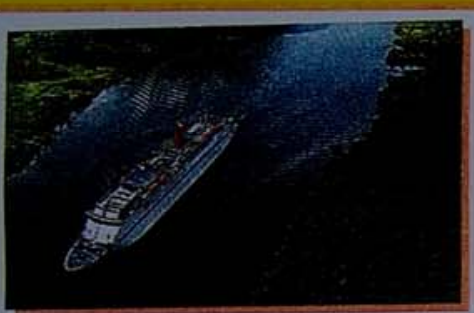

O máximo em matéria de cruzeiro Omaximo em matếria de cruzeitros de férias é sem dívida um

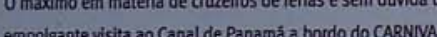
empolgame vista

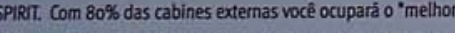
lugar do navio". Aprecie as incomparívelis belezas naturais à medida que esse navio ancora em lugares exóticos como Porto Vollara e Acapulco, no México. Depois, ao cruzar de um oceano para o outro, destumbre-se com 0 Canal de Pannamá, uma obra-prima da engenharia.

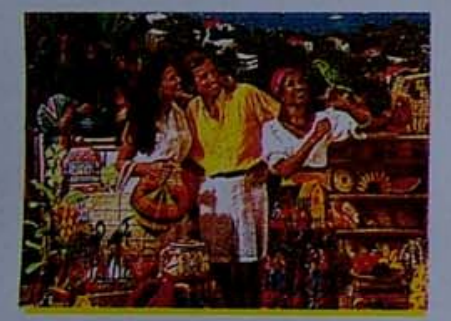

$A$ arte 00 colorido artesanato cstão por toda parte na America Central

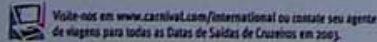

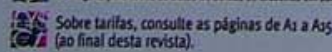

DV Veja as plentas dos decés na pisina 88.

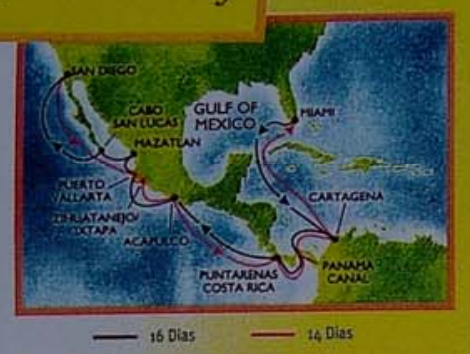

MINERARIODE I4 OIAS PELO GANAL OE PANAMA

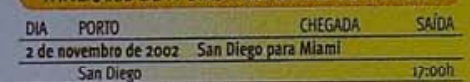

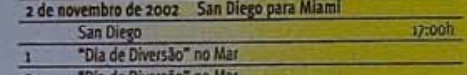

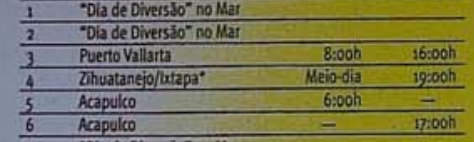

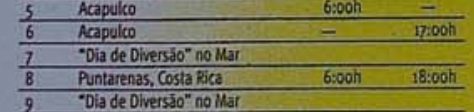

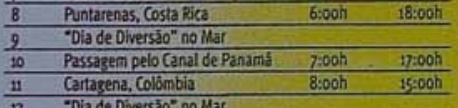

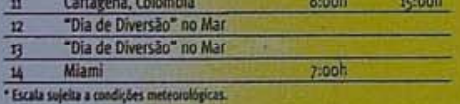

IINERIRIO DE IG OLAS PELO CANAL DE PANAMA

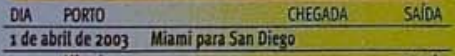

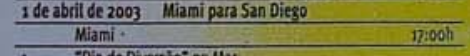

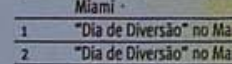

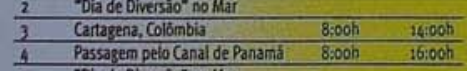

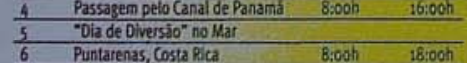
Puntarenas, Costa fica 8 "Dia de Oiversso" noll \begin{tabular}{ll}
$\frac{7}{9}$ & Acapulke \\
\hline 10 & Acaroulco \\
\hline &
\end{tabular}

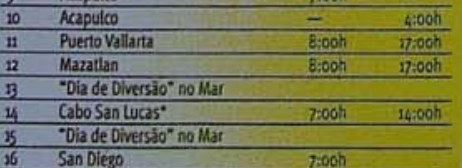

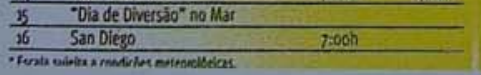

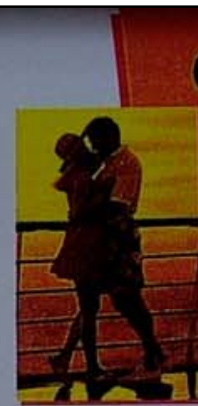

A cidade à beira da baía verdadeira pérola da natureza, é preciso que você veja Tampa e a costa do gollo. Seja o que for que vocẻ mais aprecie, Tampa Bay tern de tudo: praias de areias brancas, trilhas em meio à natureza cheia de paz, as maiores equipes esportivas, inctiveis shopping centers, barcos e pescaria, e um mundo de música, arte e eventos culturais. Da agitada vida noturna de Ybor City à badalação de compras ao longo do revo poto Bay é um lugar que agrada a todos. Para quem deseja ainda mais aventura, Orlando e suas inúmeras atraçōes ficam a apenas uma hora de distância, de carro.

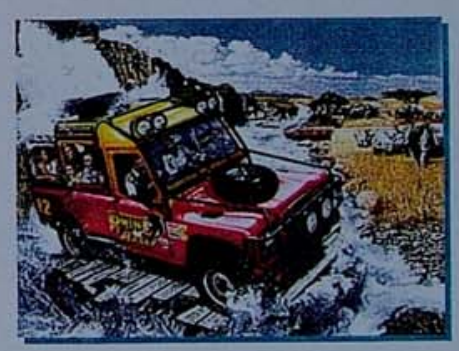

Milhares de opföes

Teatros ao estilo Las Vegas, shows ao ar livre, animais majestosos e passeios em eletrizantes brinquedos dão uma idếia do que seja diversăo no principal parque temático da Fbich aquáticas e seis montanhas-russas - mais do que em qualquer outro parque do Estado. A mais nova atrą̧ăo è "Rhino Rally", que leva os visitantes a um safárit. exibindo mais de dezes. sete espécies exóticas, e um eletrizante passeio pelo rio.

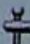

Seanort St Terminal 
ANEXO 19 


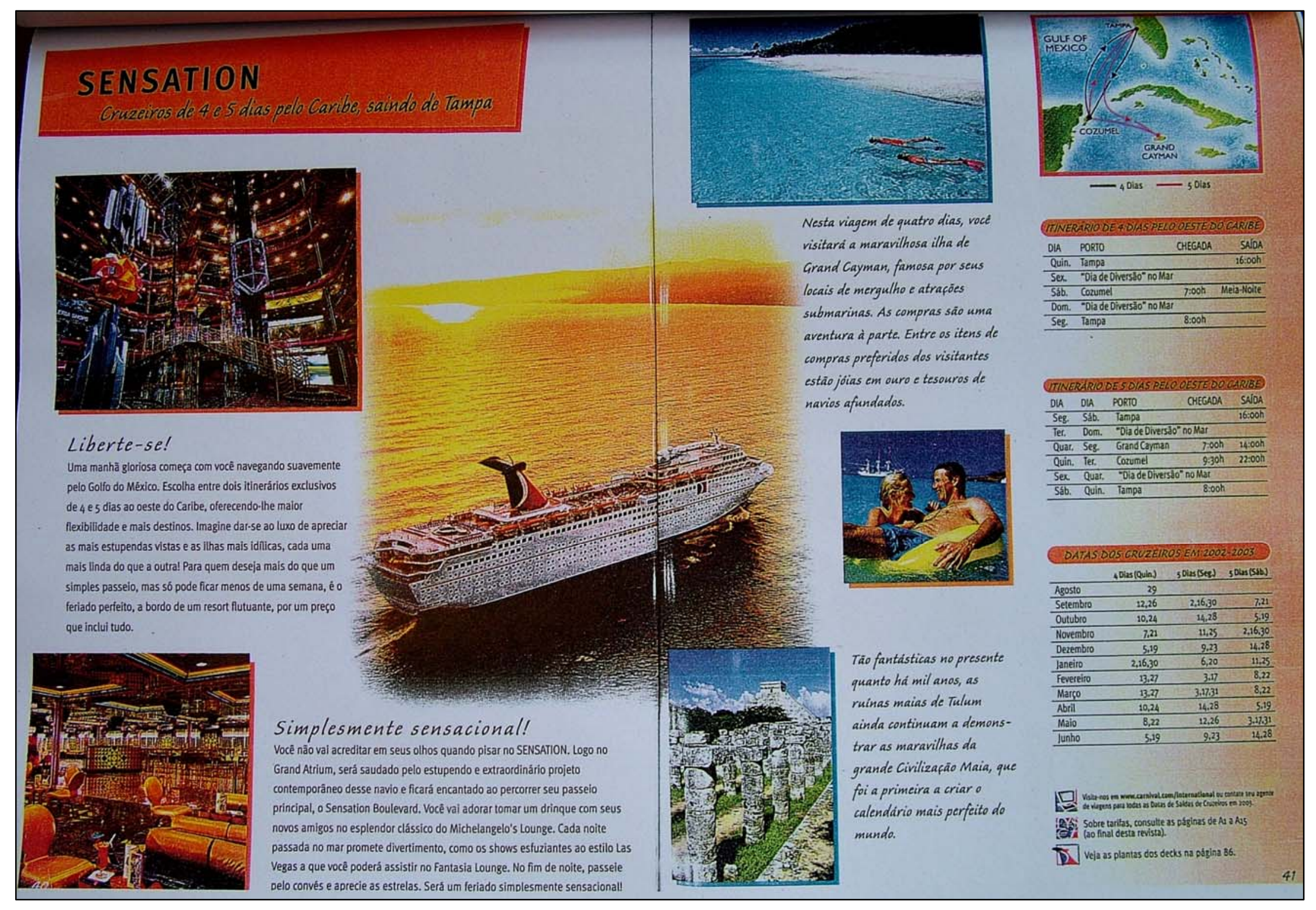


ANEXO 20 


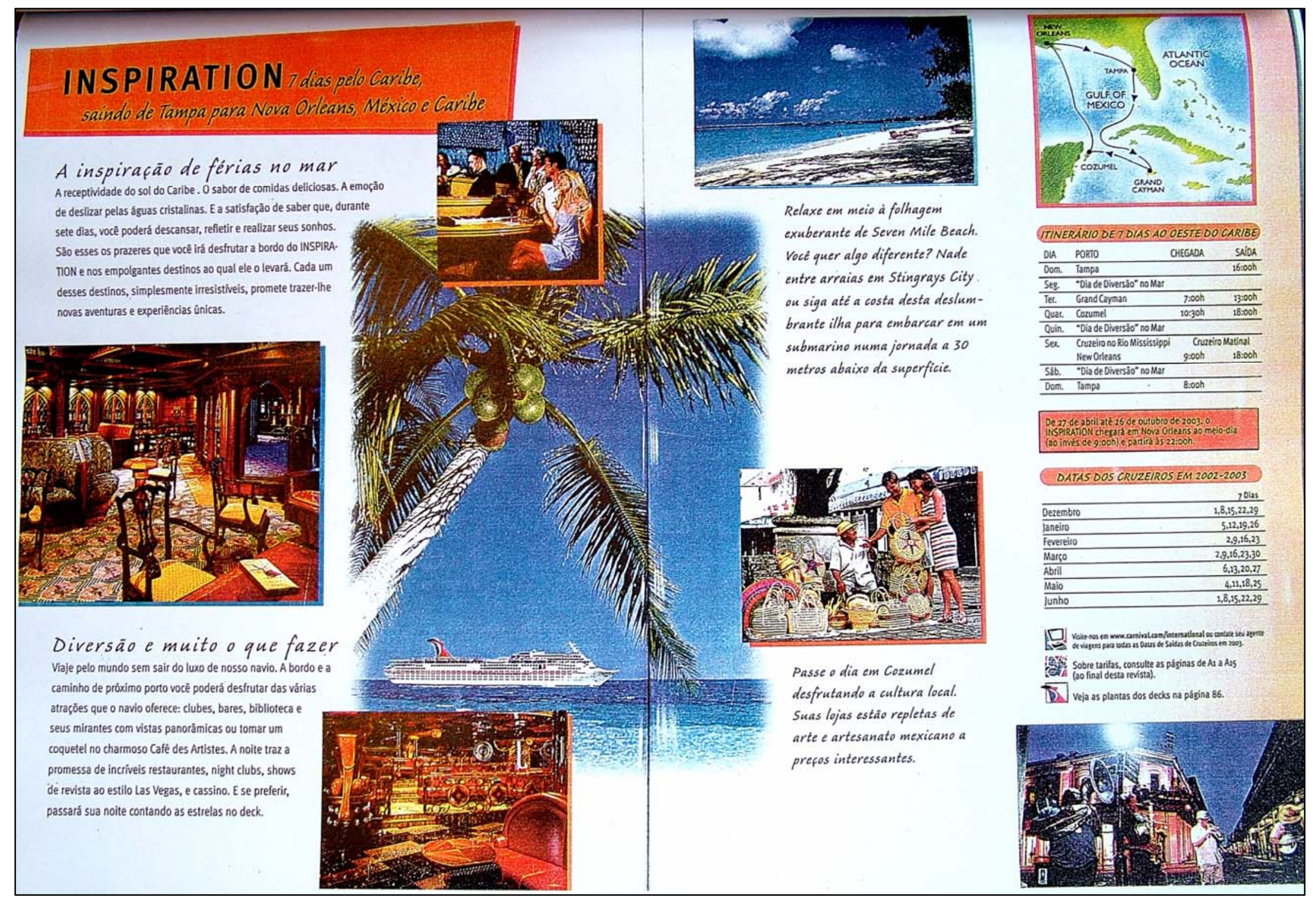


ANEXO 21 


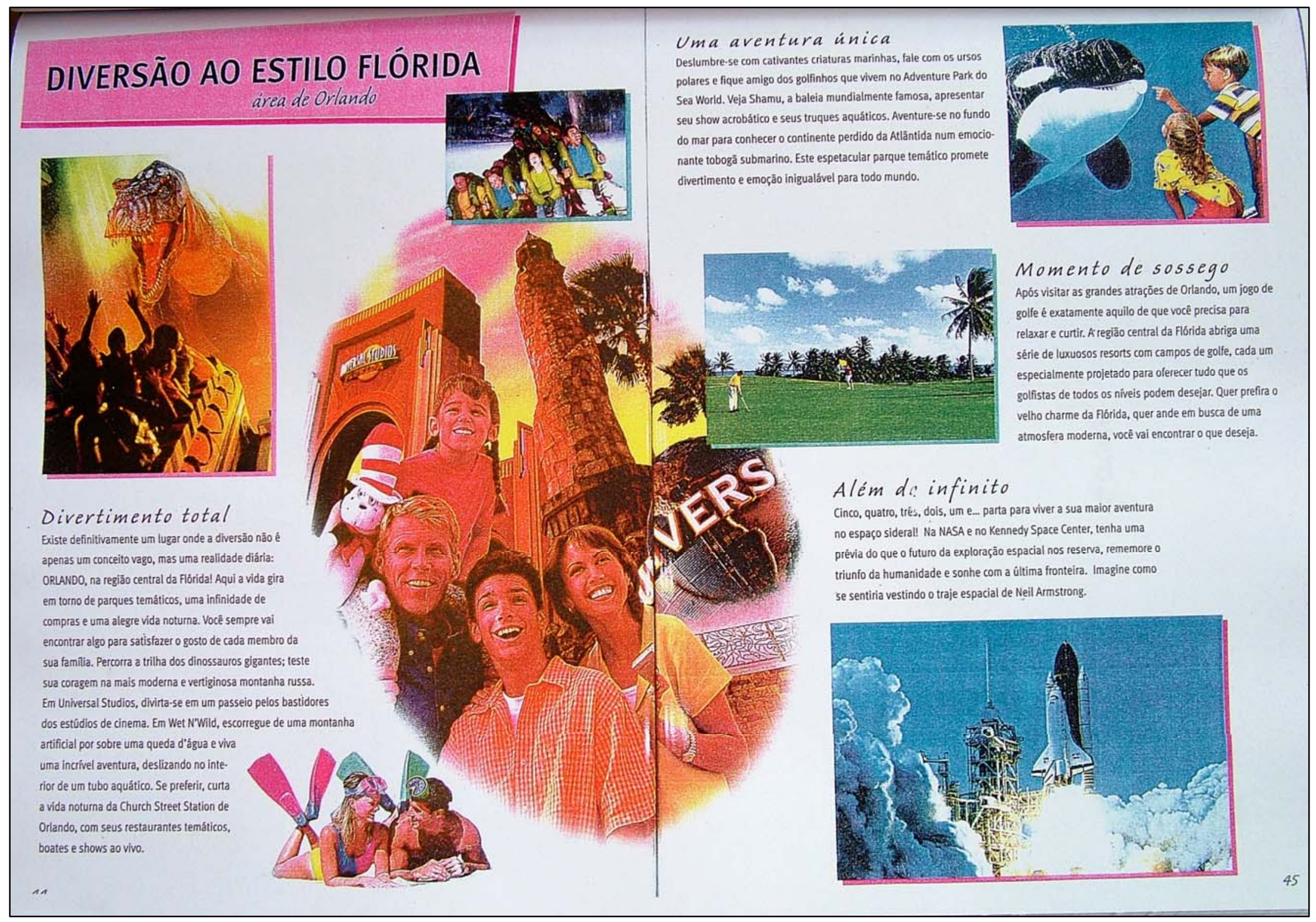


ANEXO 22 


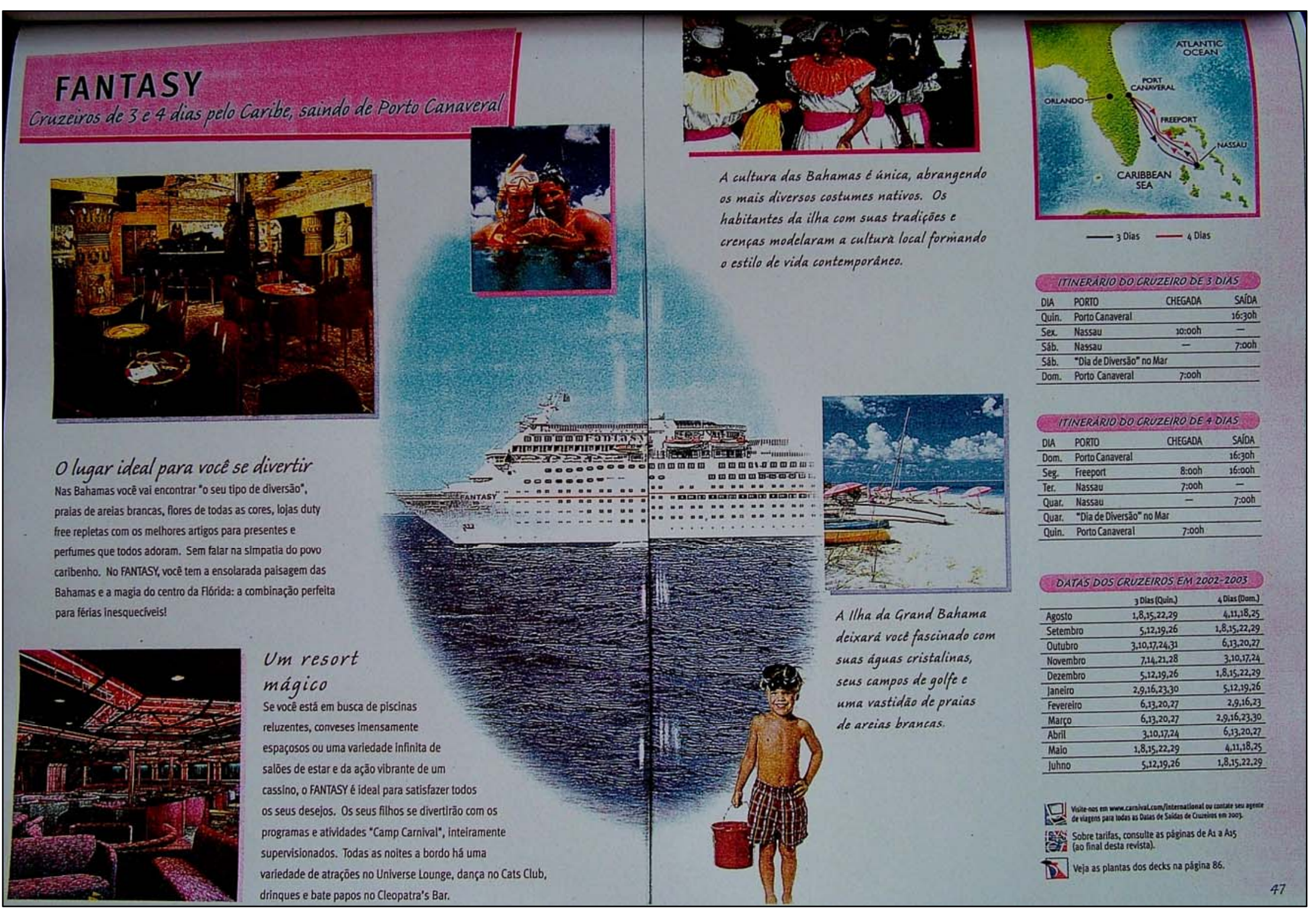


ANEXO 23 


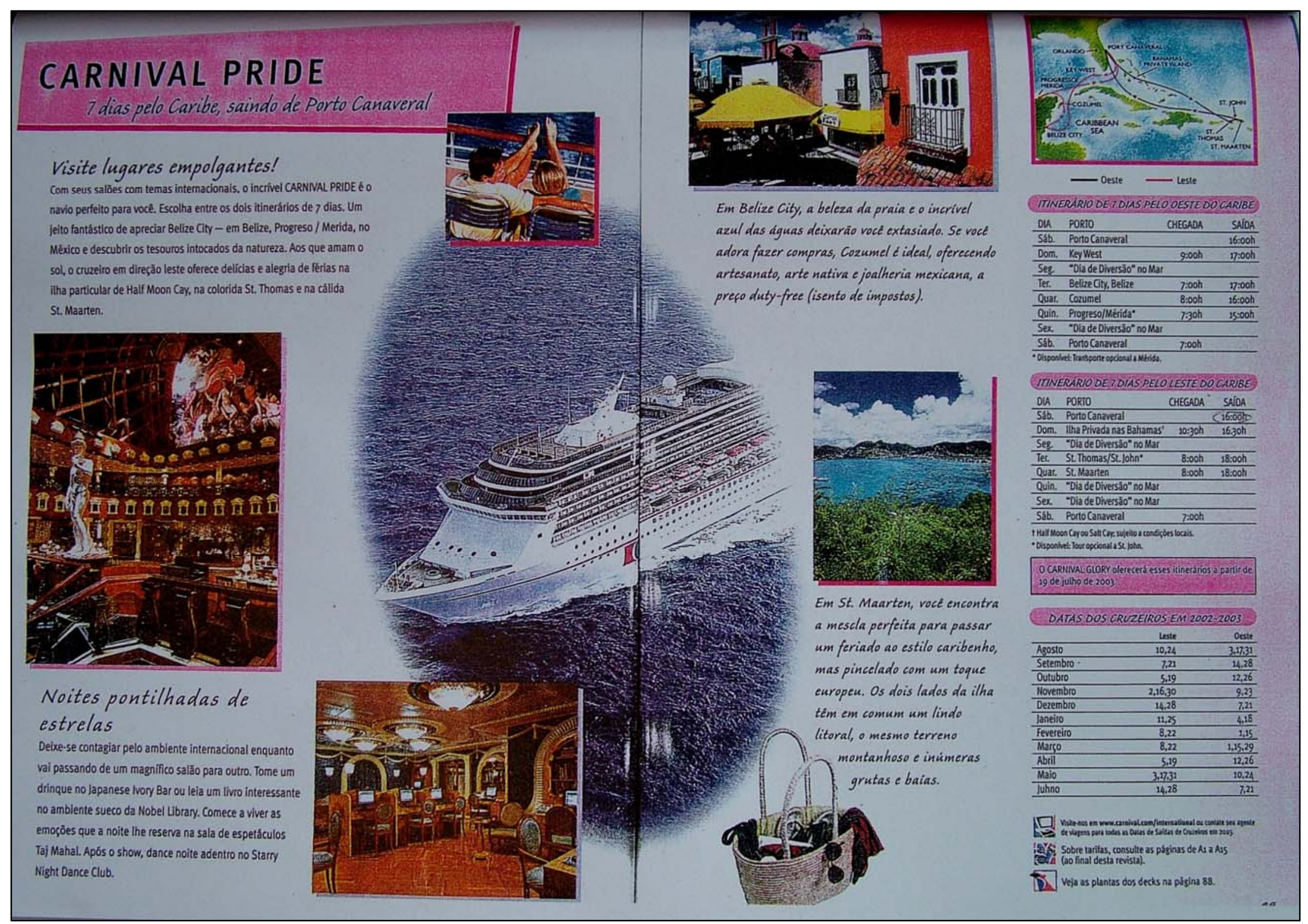


ANEXO 24 


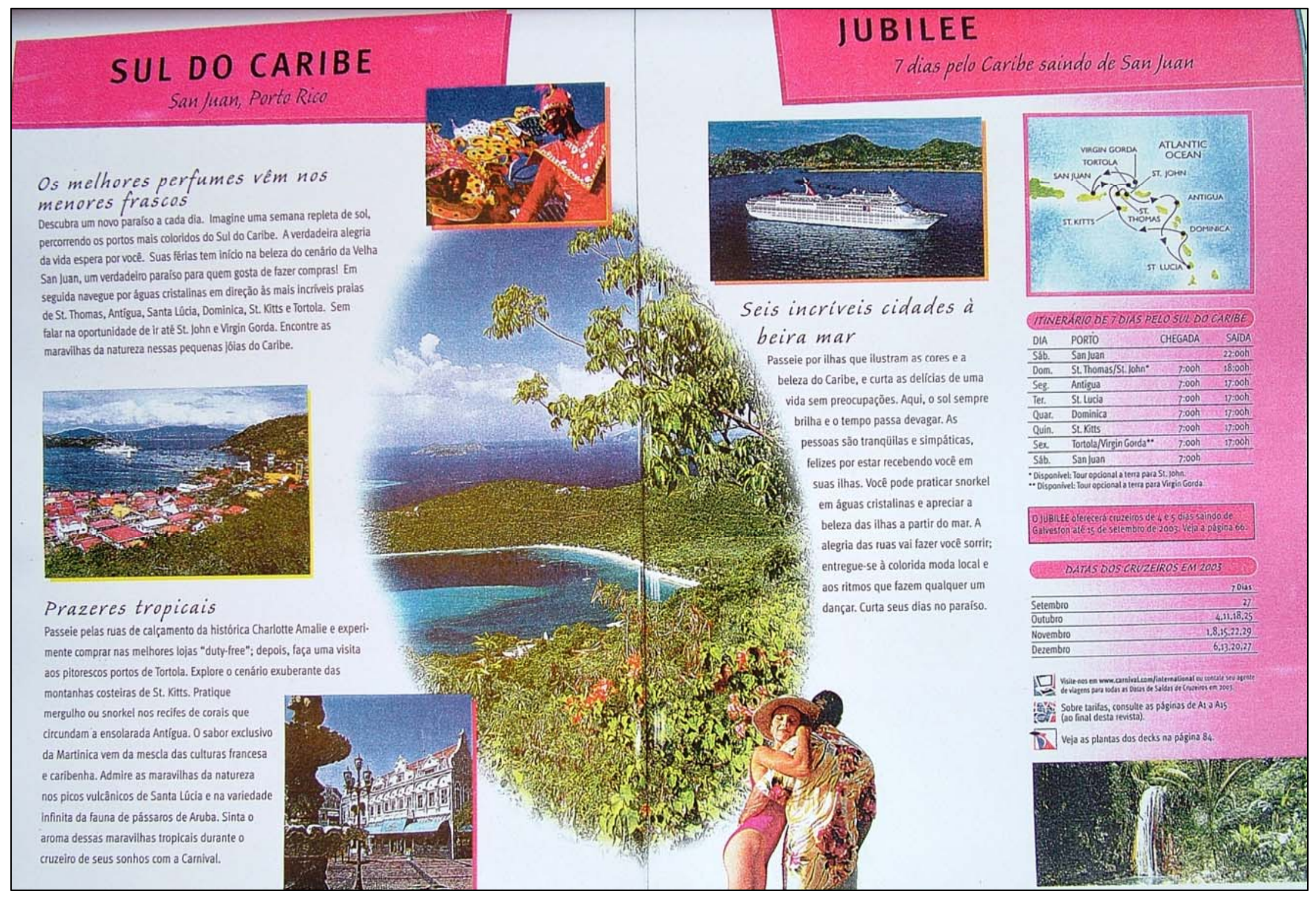




\section{ANEXO 25}




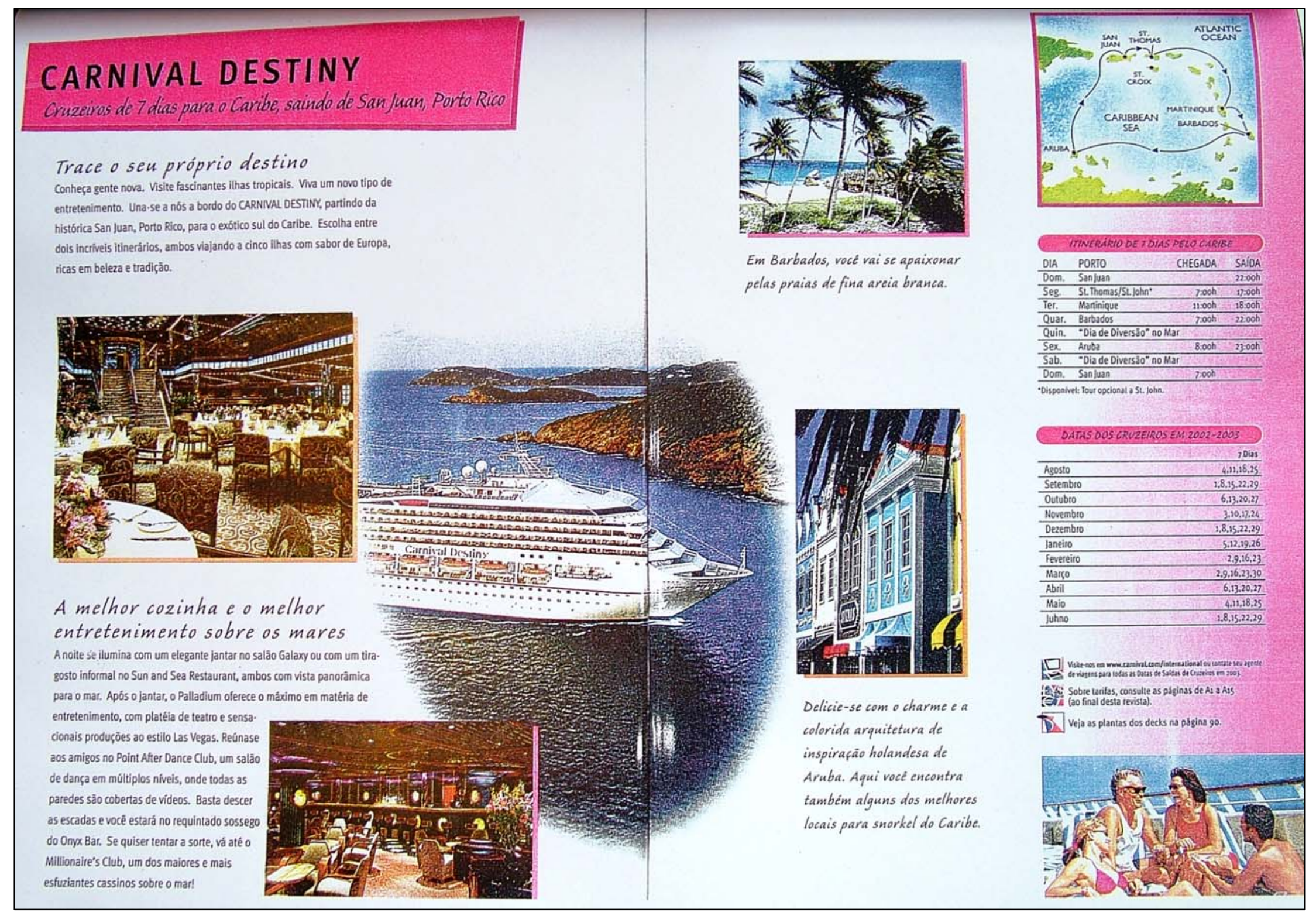




\section{ANEXO 26}




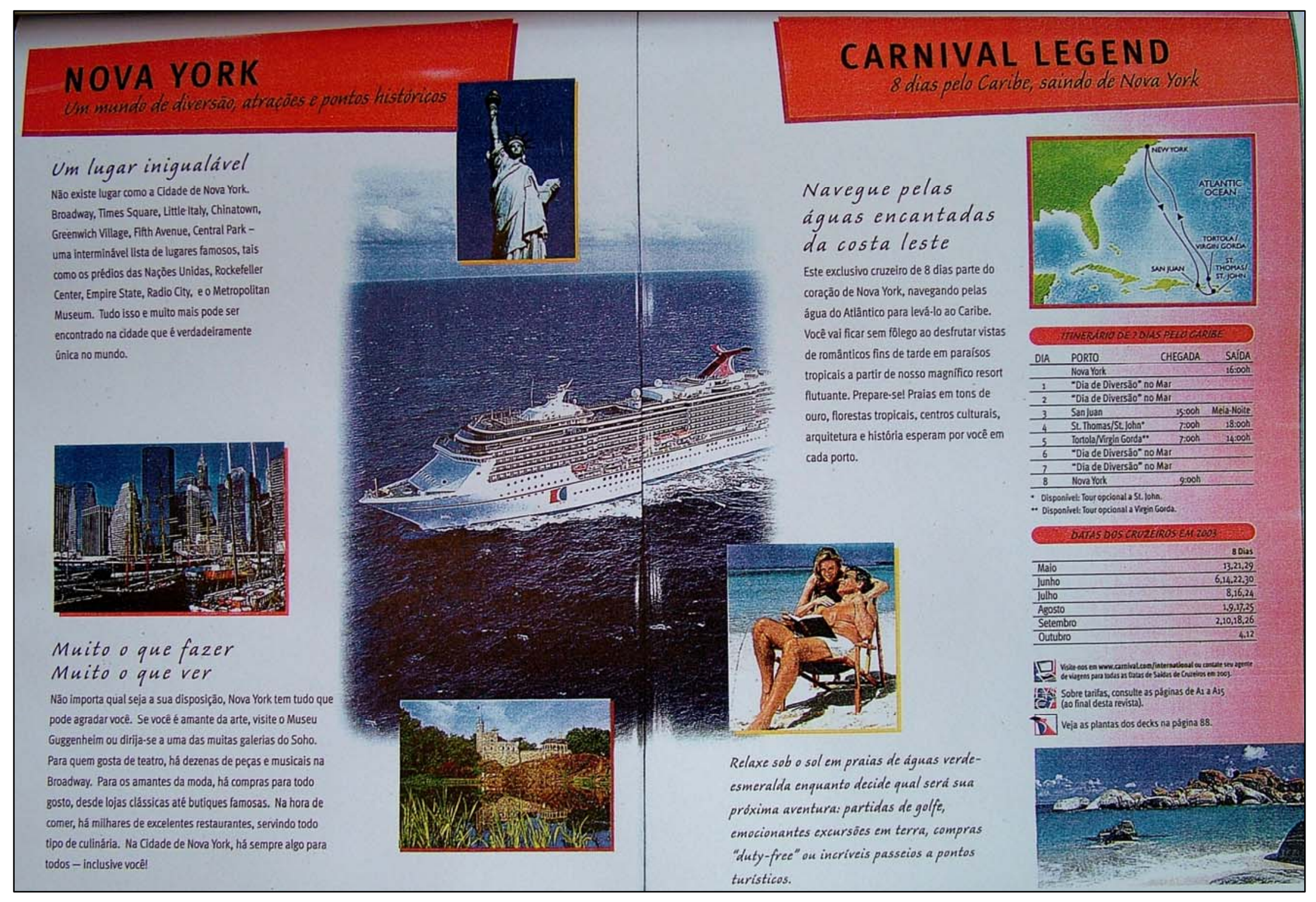


ANEXO 27 


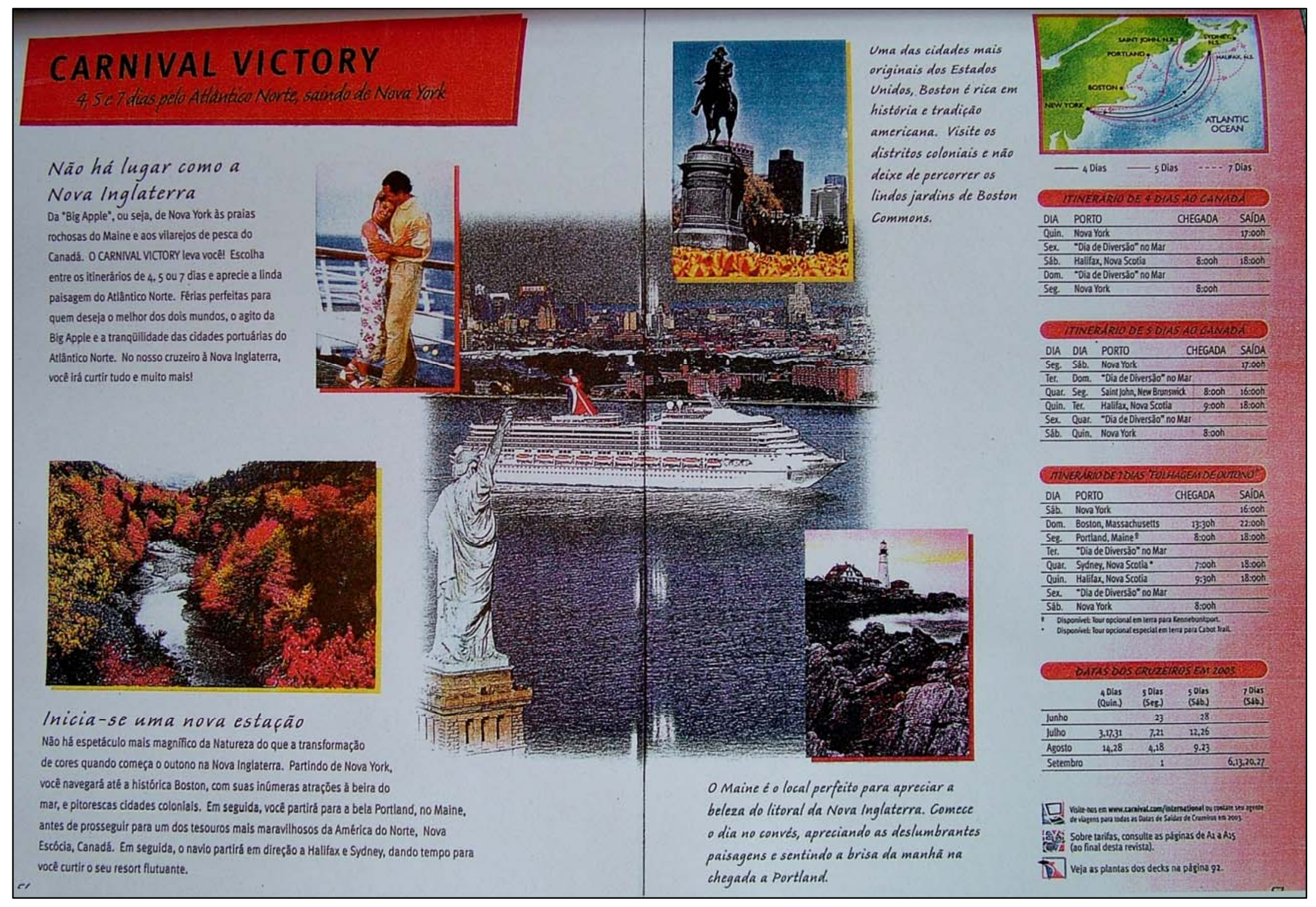


ANEXO 28 


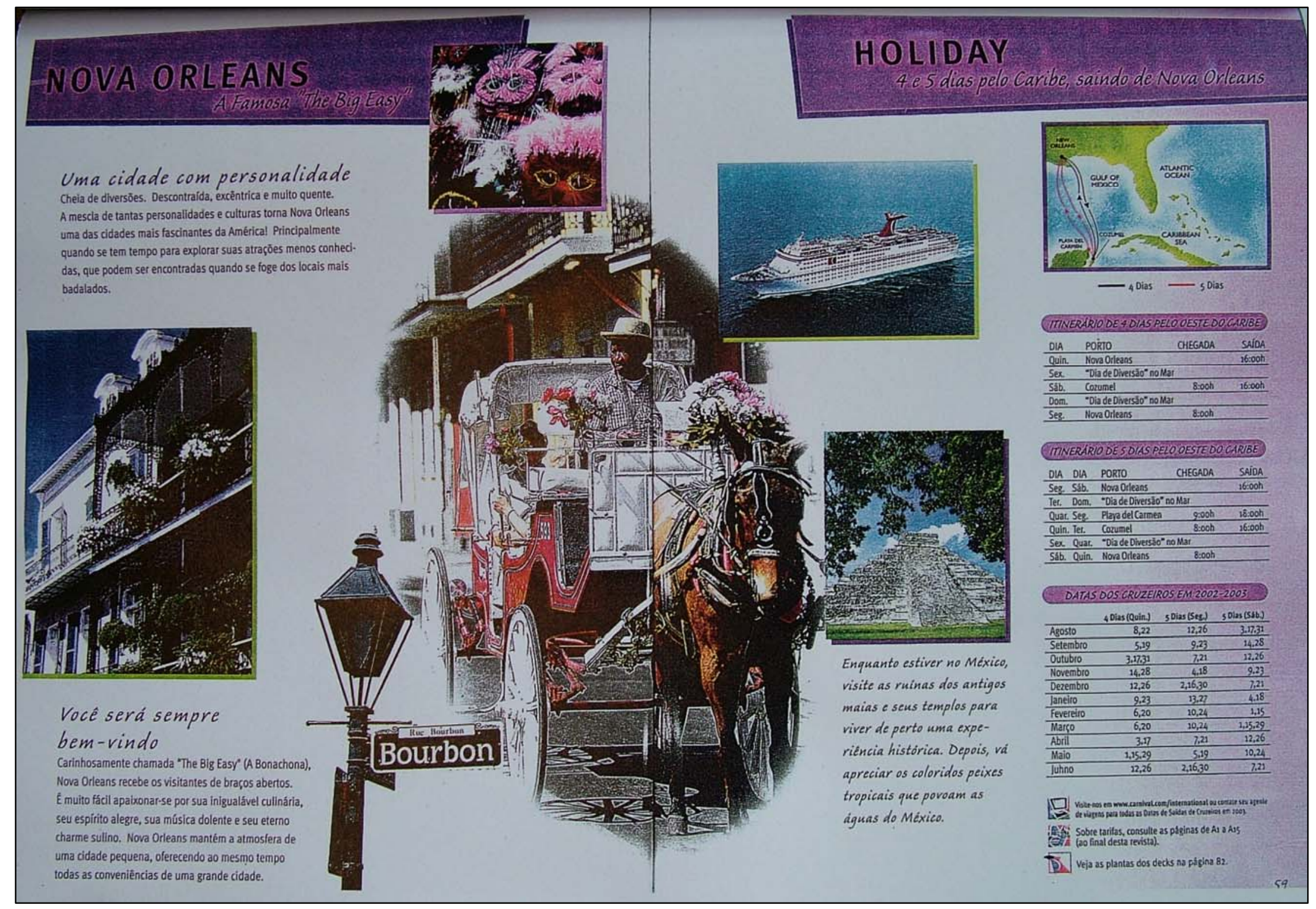




\section{ANEXO 29}




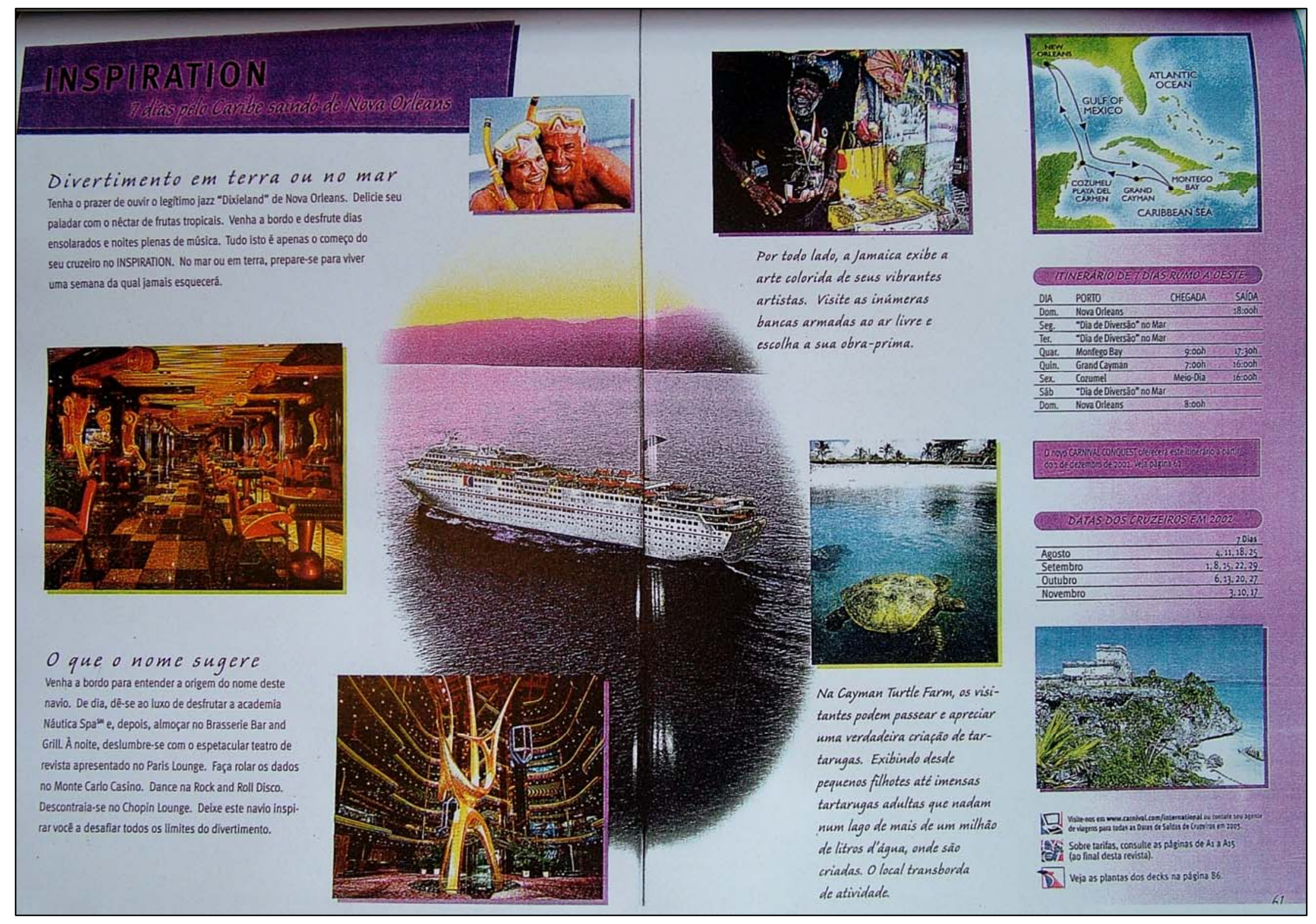




\section{ANEXO 30}




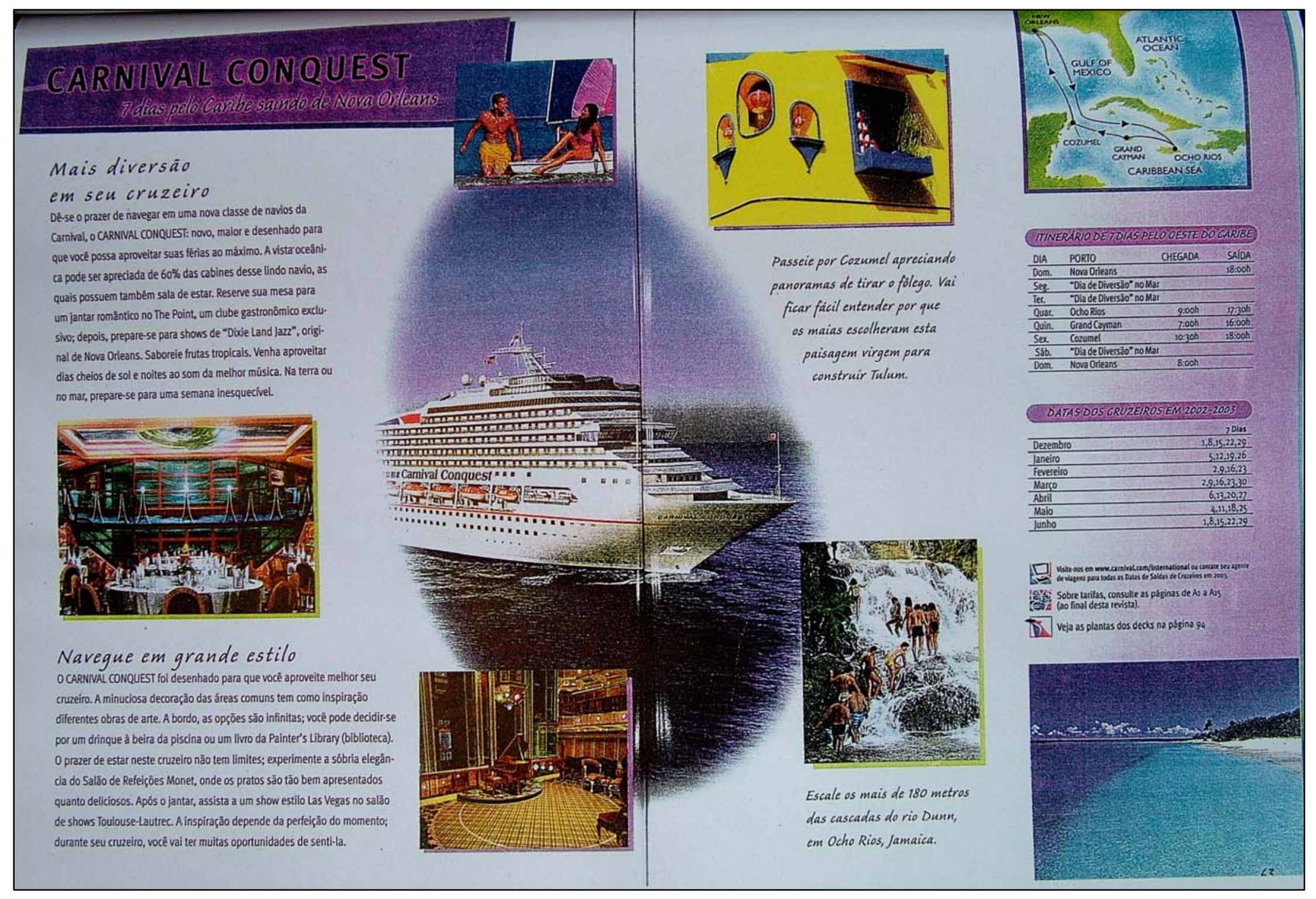




\section{ANEXO 31}




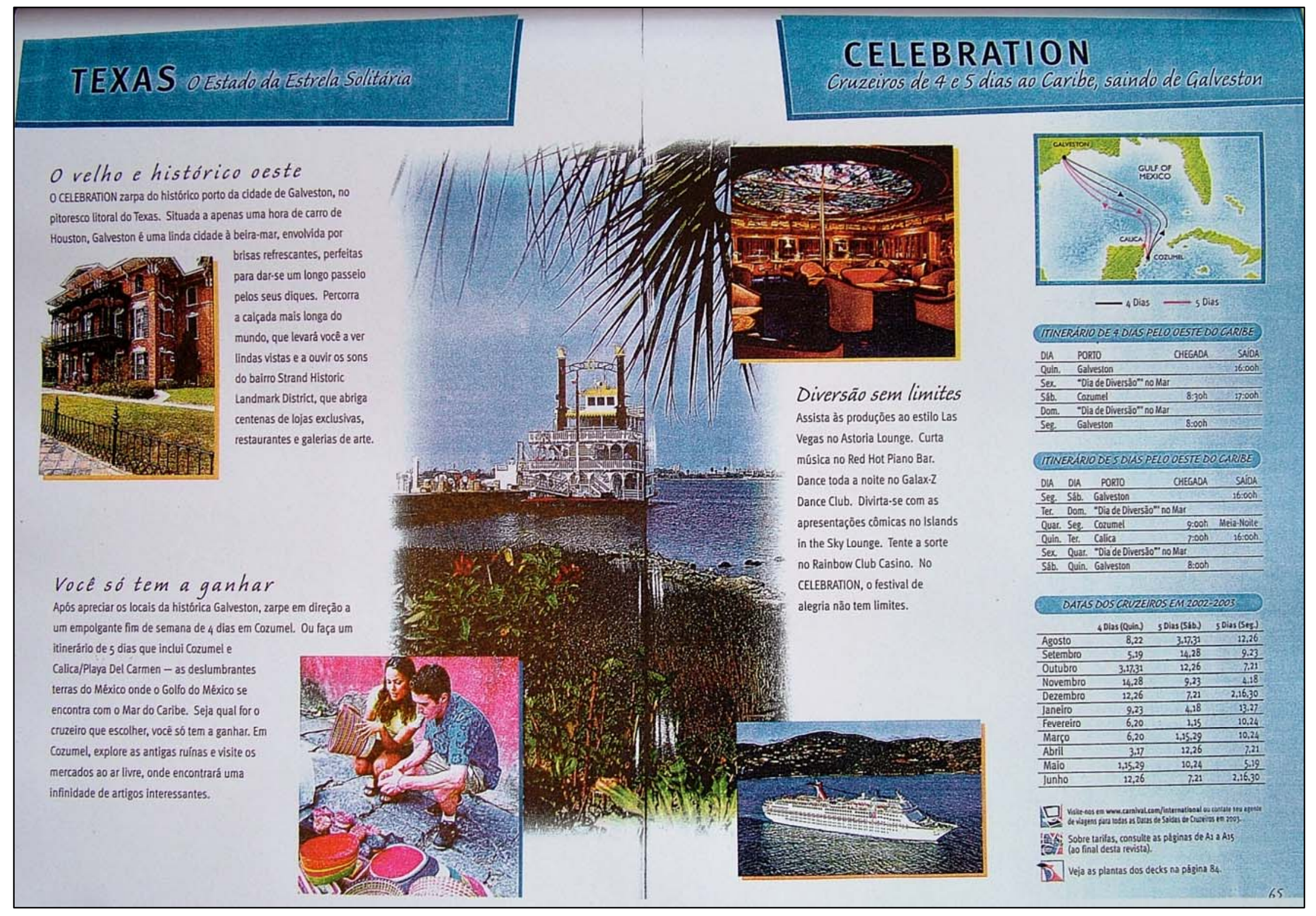


ANEXO 32 


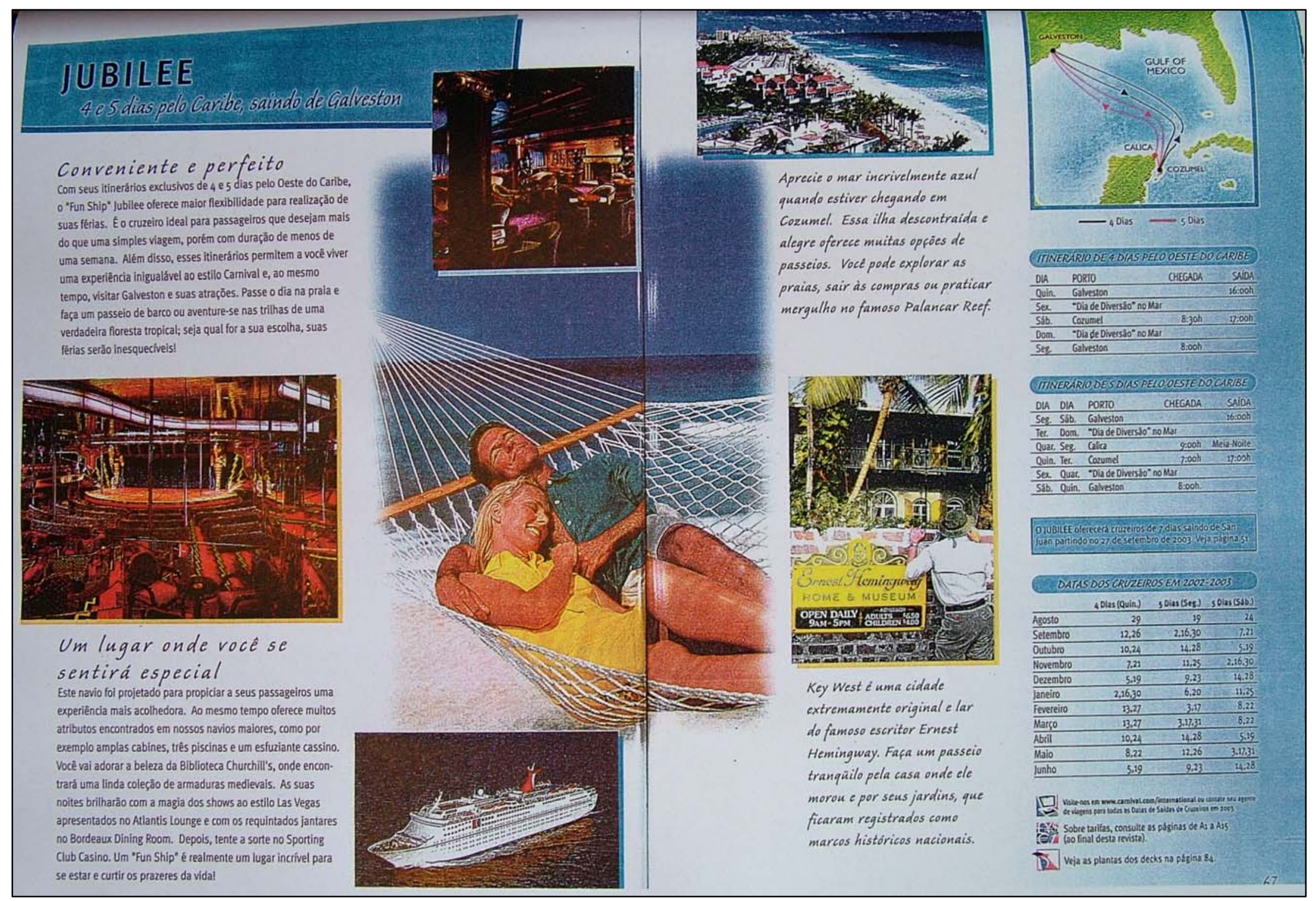


ANEXO 33 


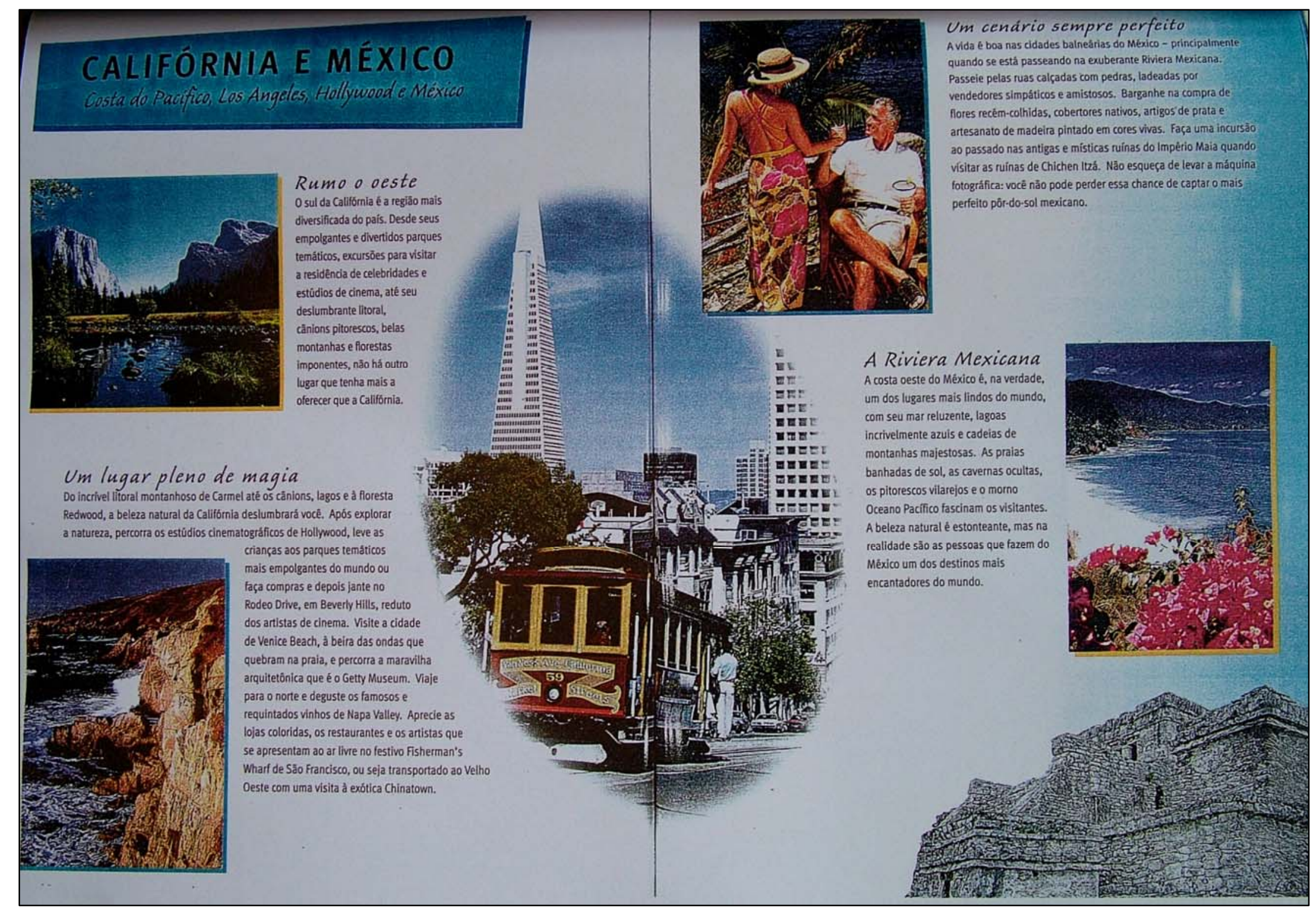


ANEXO 34 


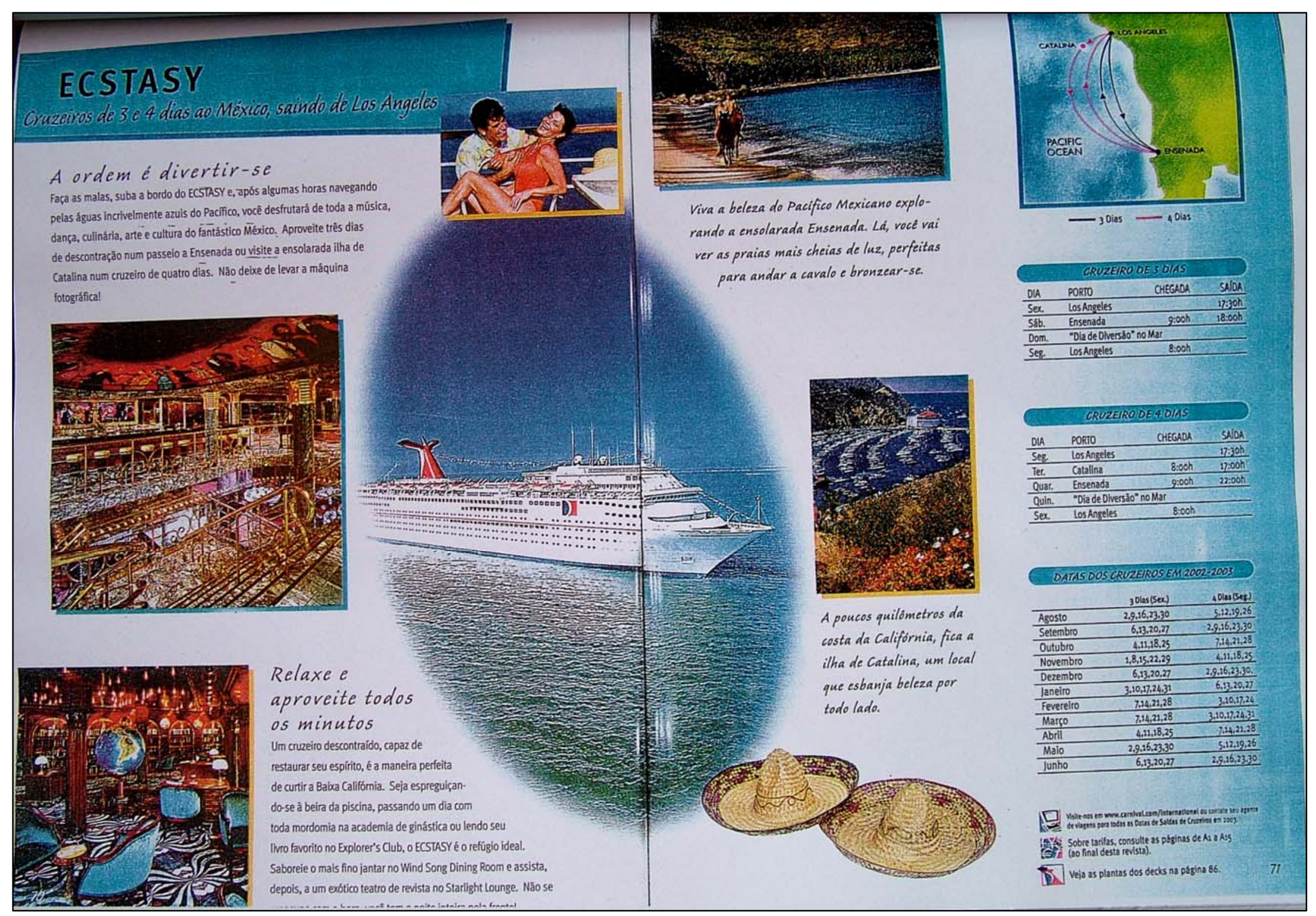




\section{ANEXO 35}




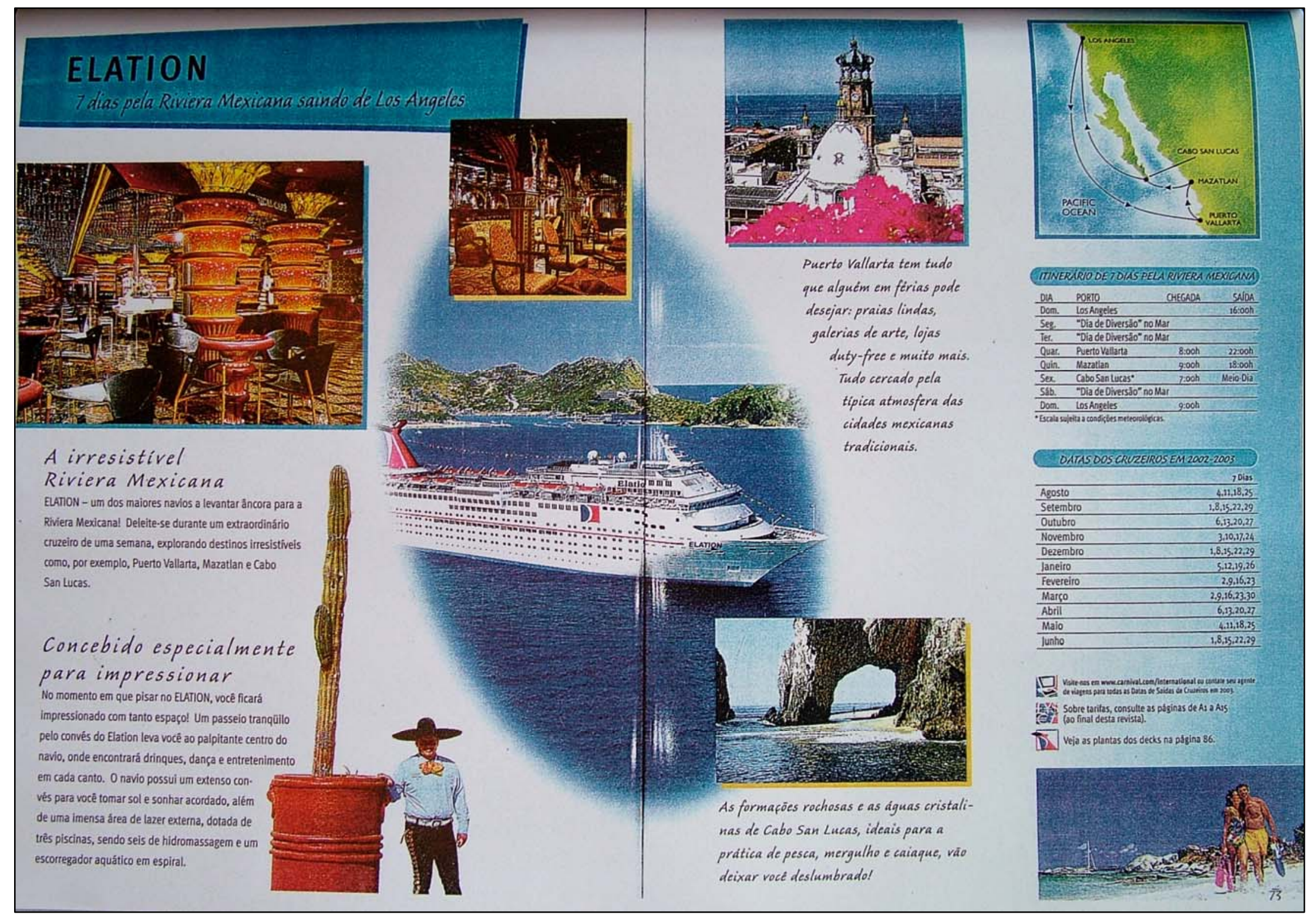




\section{ANEXO 36}




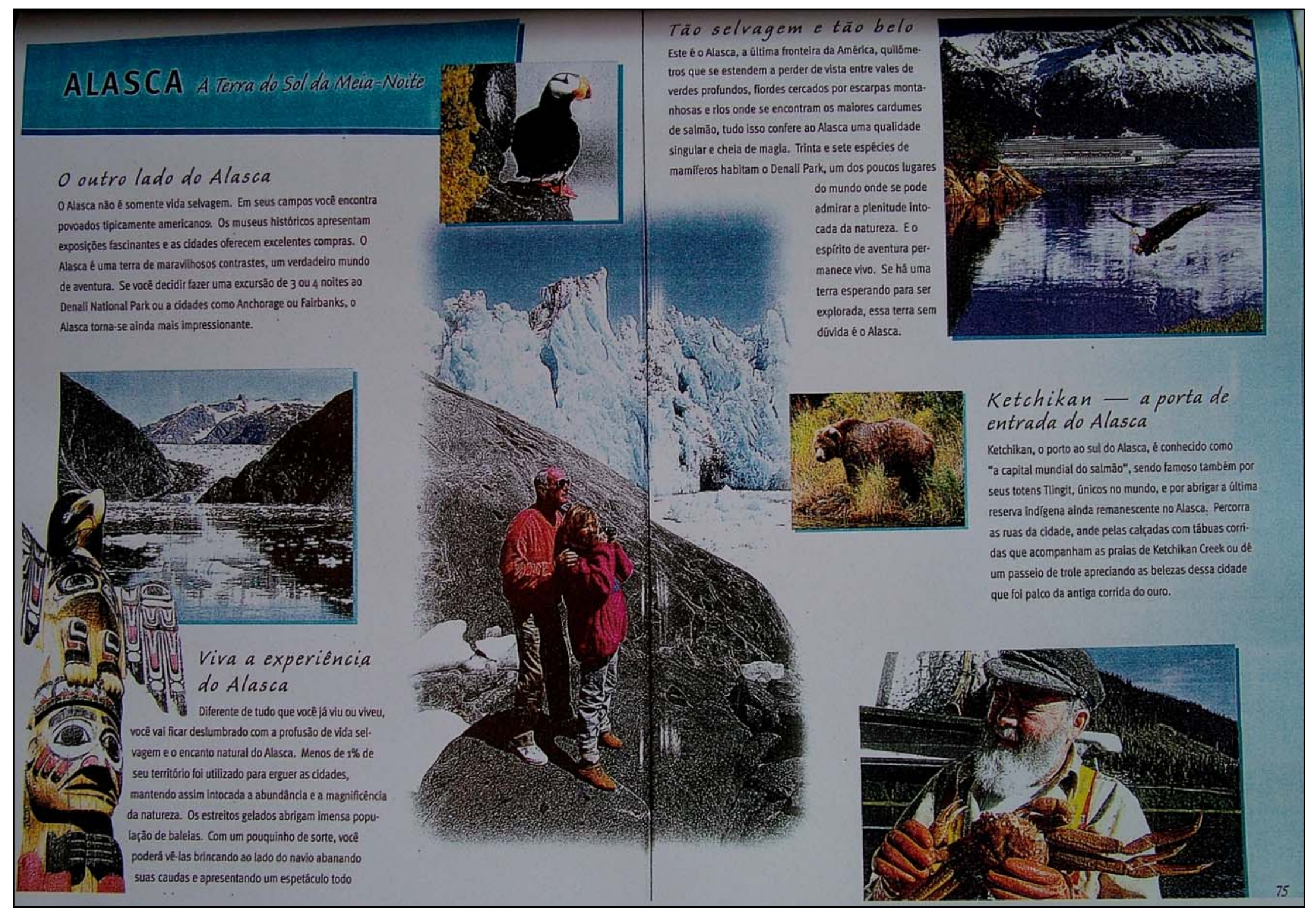


ANEXO 37 


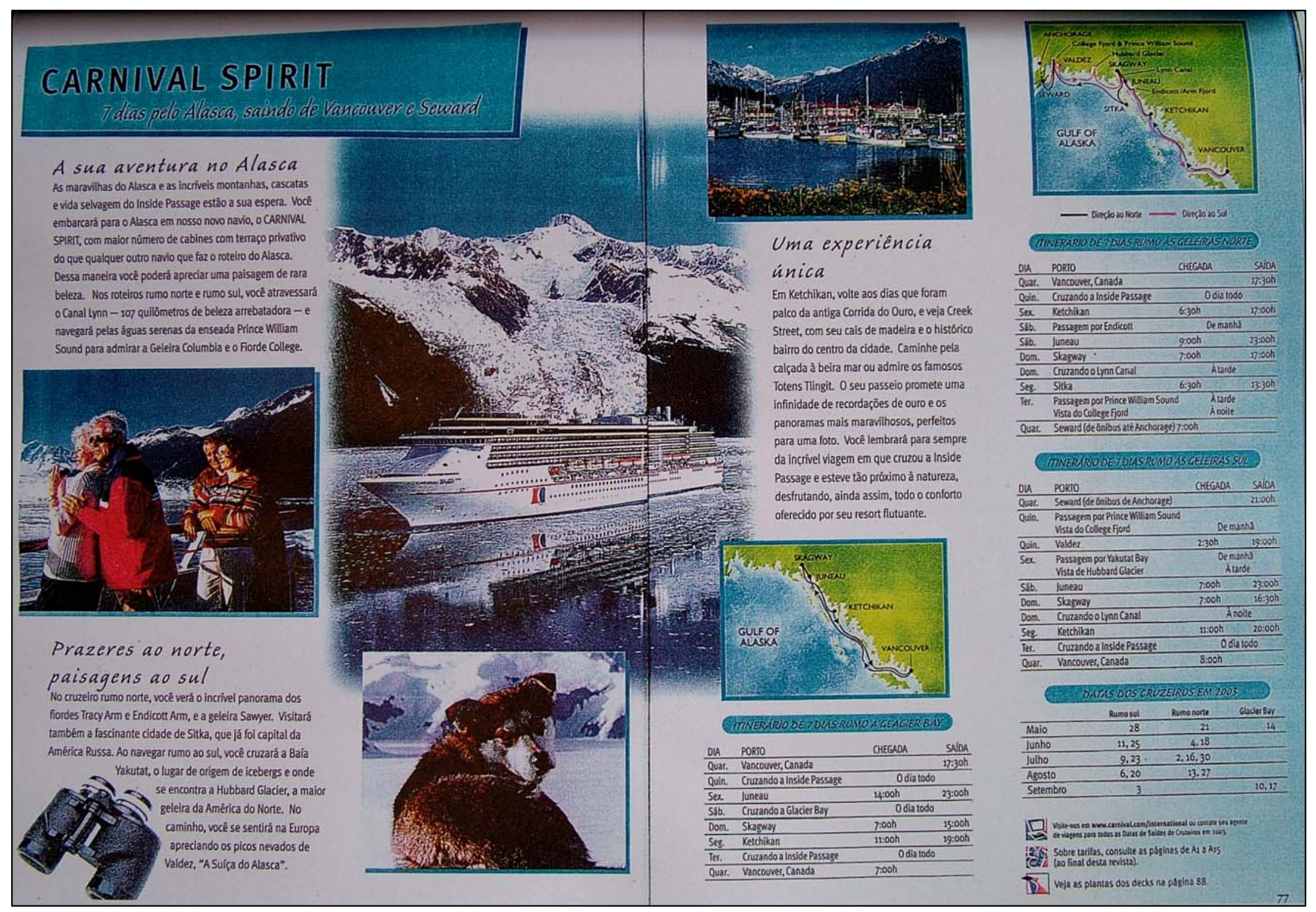




\section{ANEXO 38}




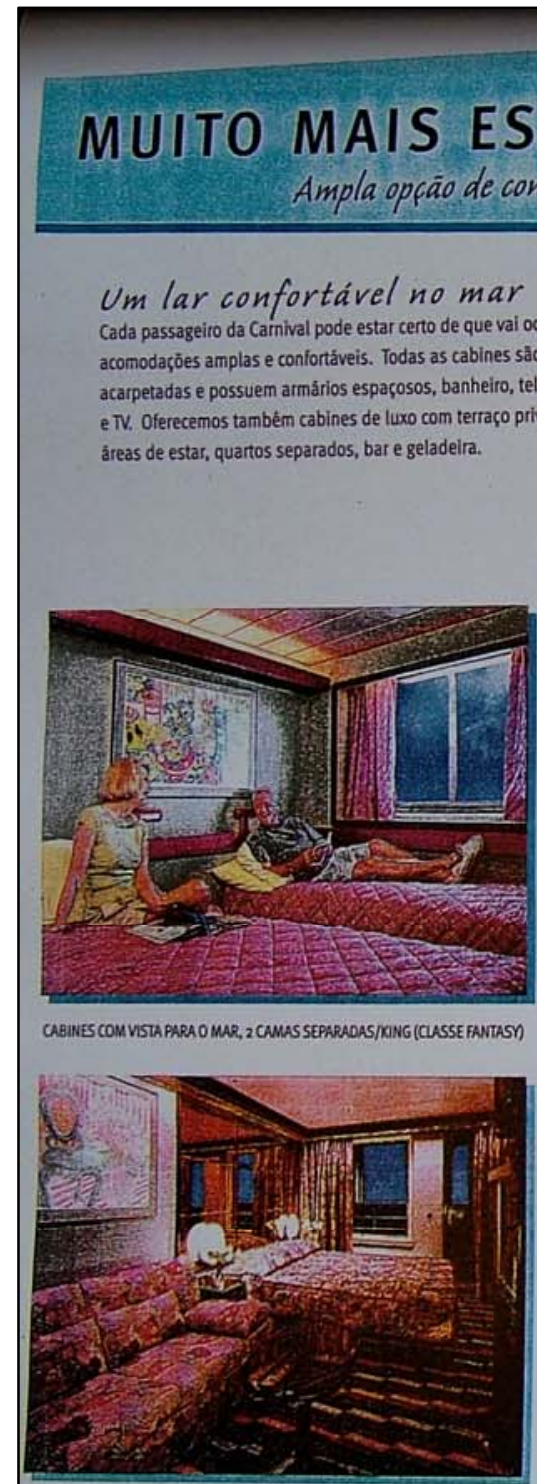

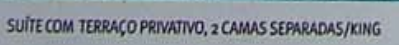

o mesmo nivel de atendimento para todos os passageiros Quer vocé escollha uma cabine interna ou uma sutte de luxo. receberá o mesmo atendimento rápiduo e eiciciente de sed camareiro, o qual, como num passe de mágica, manter sua crobine sempre anumada. Se vocể desejar um lanchí ou uma comida leve, nảo se esqueşa do room sevice 24 horas. À distância é apenas de um telefonema.
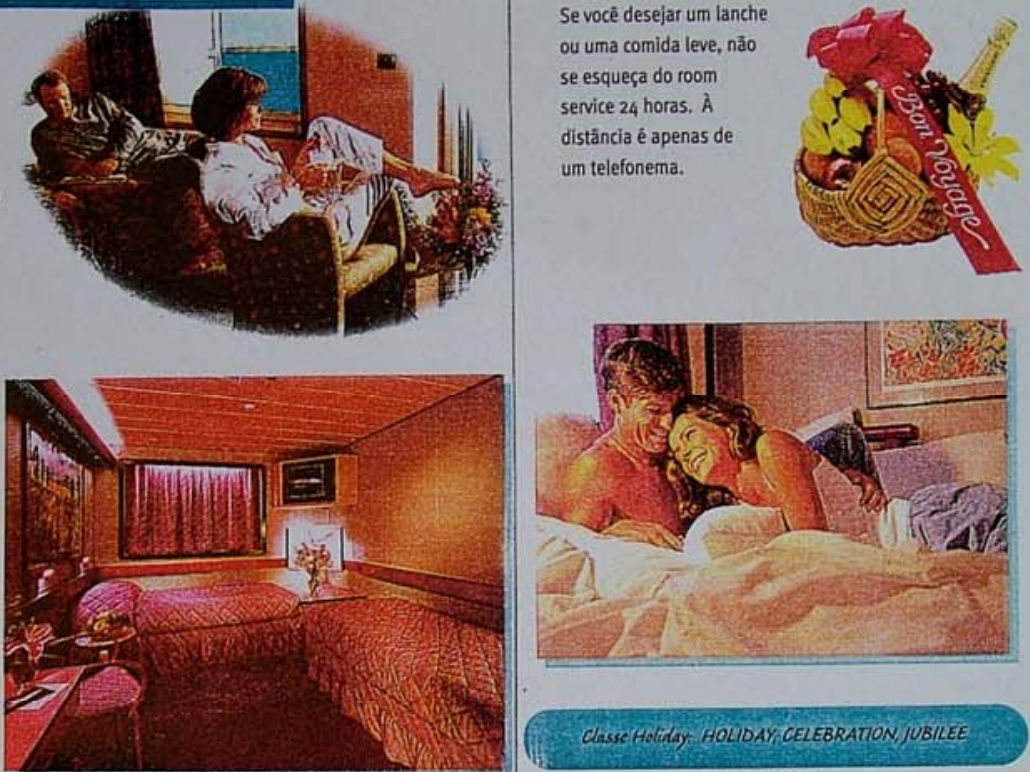

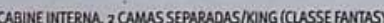

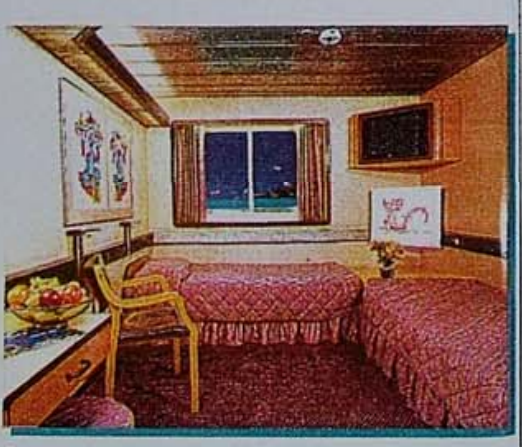

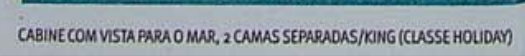

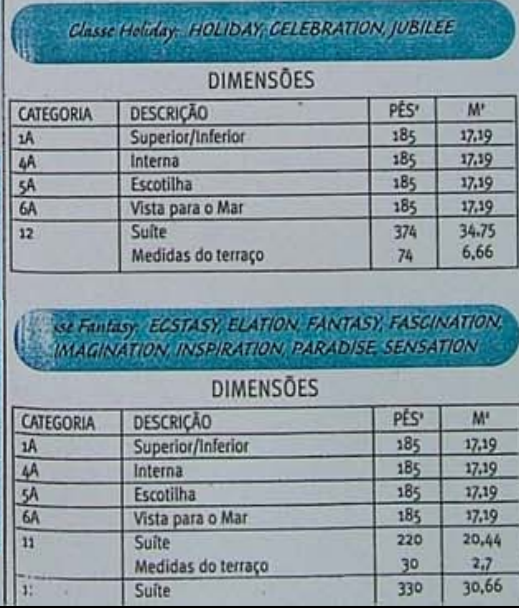

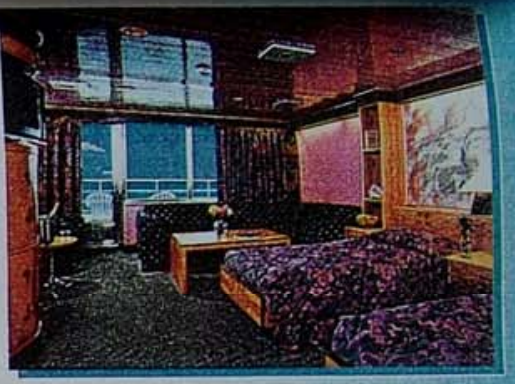

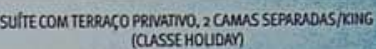

Escolha as acomodacoies perfeitas

Emuito simples escolher a cabine ideal para suas necessidades Nossos Supertiners possuem cabines espacosas, tornando sua viagem mais confortável.

Casais: A grande maioria de nossas cabines possuem camas separadas que podem ser lacilmente convertidas em uma cama king size. Portanto, se vocé estiver em lua-de-mel, escolha uma cabine nas categorias $4 A$ a $6 D$.

Familias: As cabines com cama de solteiroe duas camas tipo beliche săo ideais. Pode-se acrescentar uma cama avulsa ou berço. Há cabines quadruplas disponiveis na maioria dos decks, marcadas com dois pontos (i) na parte inferior das plantas dos decks. (Os navios das classes Destiny e Spirit possuem cabines para familias, convenientemente localizadas próximo ao Saläo de Jogos Infantis.)

Solteiros: A tarifa de solteiro é bastante acessivel na categori A - basta acrescentar $50 \%$ à tarifa do cruzeiro. Também aco modamos passageros solteiros nas Categorias $4 A-12$, mediante o accéscimo de $100 \%$ à tarifa do cruzeiro.

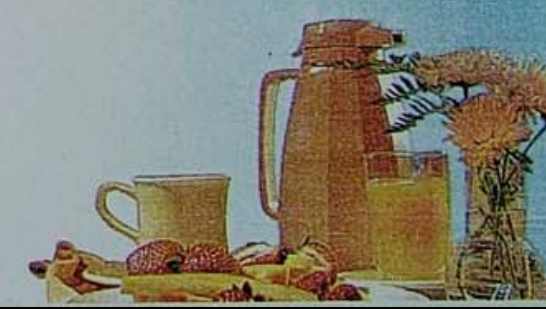




\section{ANEXO 39}




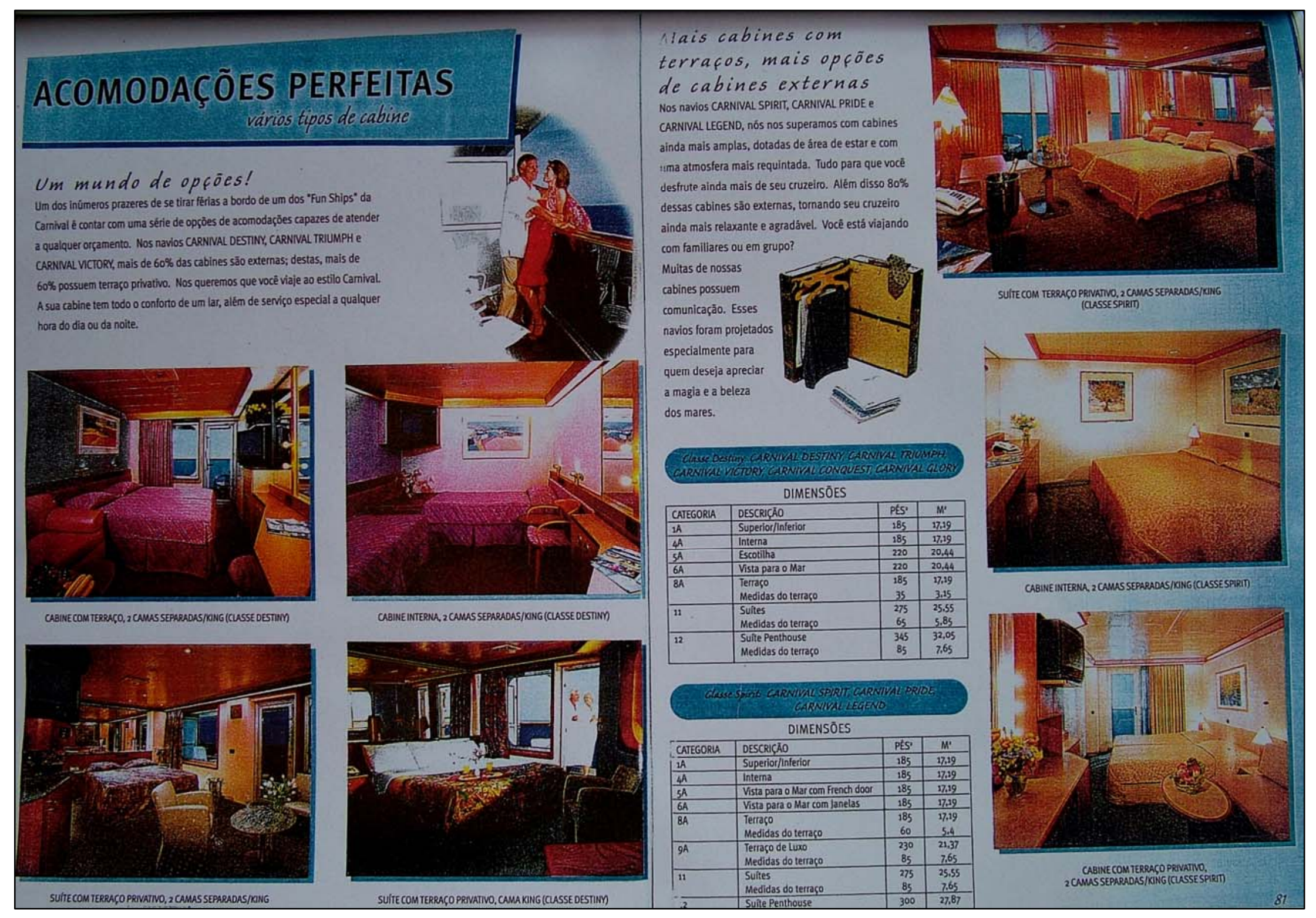




\section{ANEXO 40}




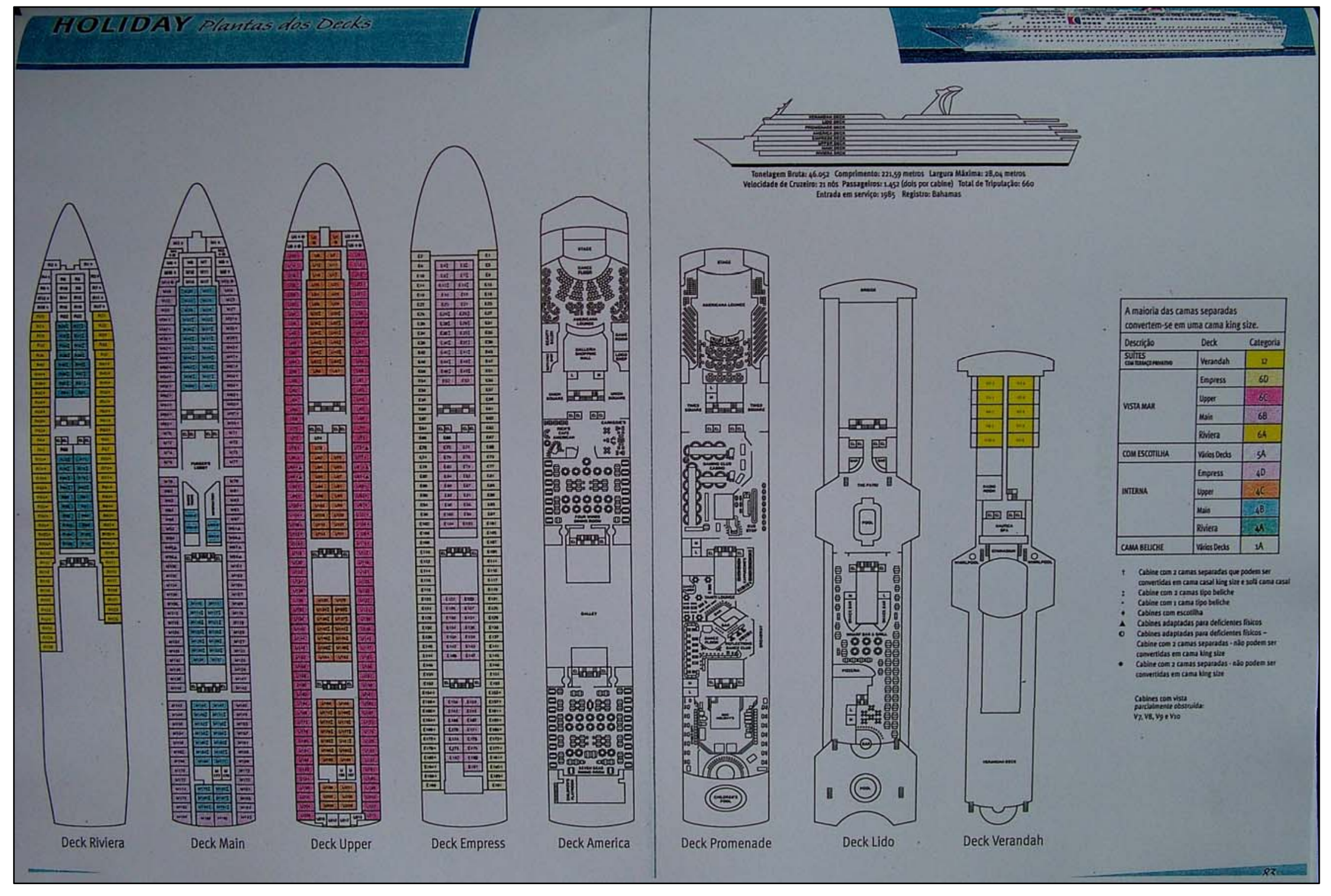


ANEXO 41 


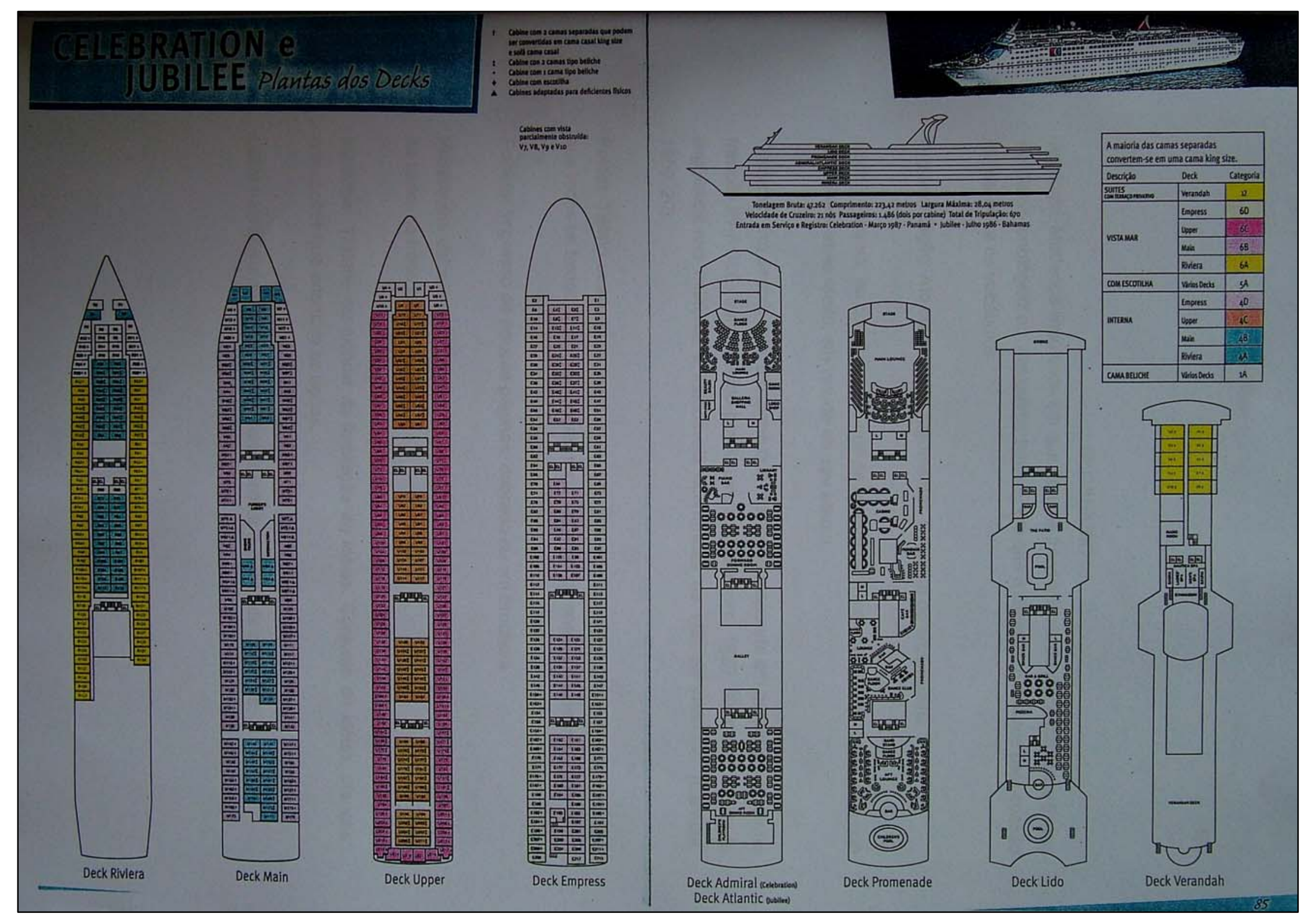




\section{GLOSSÁRIO}

Analogia: Mudança lingüística em que há uma interferência do plano formal da língua no plano fonológico ou, em outros termos, em que a fonação é afetada pela coesão formal entre os vocábulos.

Argumentação: Ato ou efeito de argumentar. Conjunto de argumentos.

Clichê: Palavra, ou construção, a que se recorre para maior expressividade, mas que já não tem esse efeito, em virtude do seu abuso.

Discurso: Em sentido lato, é o termo que melhor corresponde em português ao termo francês PAROLE, estabelecido por Saussure (Saussure, 1922, 30s). É a "atividade lingüística nas múltiplas e infindáveis ocorrências da vida do indivíduo" (Câmara, 1959, 20).

Folder: Termo usado para representar um dos sujeitos-alvos da pesquisa, uma vez que todos os textos, imagens e cores foram objetos de análise desse trabalho.

Folheto: Impresso de poucas páginas, dobrado ou em brochura.

Hierarquias discursivas: São as ordens em que aparecem os níveis do discurso na no texto, na frase e/ou na oração.

Ideologia: Tratado ou ciência da formação da idéias. Conjunto de idéias, crenças, convicções que orientam as ações.

Leitor-turista: Terminologia criada para analisar o sujeito da pesquisa. 
Lingüística: O estudo da linguagem humana, mas considerada na base da sua manifestação como língua.

Metáfora: É a figura de linguagem que consiste na transferência de um termo para um âmbito de significação que não é o seu.

Orador: Pessoa que profere discurso ou sermão.

Parâmetros discursivos: São as coordenadas em que aparecem os níveis do discurso no texto, na frase e/ou na oração.

Pragmática: Conjunto de fórmulas, praxes, nas cerimônias religiosas ou da corte. Formalidades.

Propaganda: Divulgação de idéias, princípios, de gêneros de comércio.

Psicologia: Ciência que se ocupa os fenômenos psíquicos e do comportamento humano e animal.

Publicidade: Propaganda por anúncios, cartazes, folders e/ou folhetos.

Retórica: Estudo da linguagem greco-latino, que focalizava a atividade literária conhecida como discurso.

Sedução textual: Artifício usado para convencer o leitor de que determinado pacote turístico é agradável e/ou útil para os seus objetivos.

Semântica: Estudo da significação da formas lingüísticas. Em regra, assim se focaliza apenas a significação externa das palavras concentrada no radical. 
Sociologia: Estudo do desenvolvimento e da estrutura da sociedade e das relações sociais.

Turismo: Viagem ou excursão com objetivos recreativos, culturais ou por prazer. 